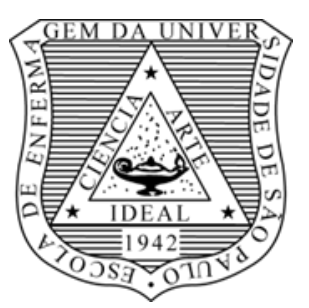

UNIVERSIDADE DE SÃO PAULO

ESCOLA DE ENFERMAGEM

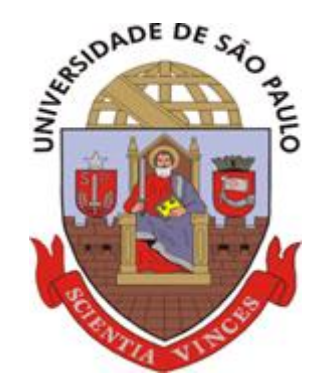

NATÁLIA RODRIGUES MOSCA

INSTRUMENTO DE APOIO DA(O) ENFERMEIRA(O) PARA CUIDADO À FAMÍLIA NA ATENÇÃO PRIMÁRIA À SAÚDE 


\title{
NATÁLIA RODRIGUES MOSCA
}

\section{INSTRUMENTO DE APOIO DA(O) ENFERMEIRA(O) PARA CUIDADO À FAMÍlIA NA ATENÇÃO PRIMÁRIA À SAÚDE}

\author{
Versão corrigida da Dissertação apresentada ao \\ Programa de Pós-Graduação Mestrado \\ Profissional em Enfermagem na Atenção \\ Primária a Saúde no SUS da Escola de \\ Enfermagem da Universidade de São Paulo \\ para obtenção do título de Mestra em Ciências. \\ Área de concentração: Cuidado em Atenção \\ Primária em Saúde \\ Orientadora: Profa. Dra. Sayuri Tanaka Maeda
}

\section{VERSÃO CORRIGIDA}

A versão original encontra-se disponível na Biblioteca Wanda Aguiar Horta da Escola de Enfermagem da Universidade de São Paulo e na Biblioteca Digital de Teses e Dissertações da Universidade de São Paulo. 
AUTORIZO A REPRODUÇÃO E DIVULGAÇÃO TOTAL OU PARCIAL DESTE TRABALHO, POR QUALQUER MEIO CONVENCIONAL OU ELETRÔNICO, PARA FINS DE ESTUDO E PESQUISA, DESDE QUE CITADA A FONTE.

Assinatura:

Data:

\section{Catalogação na Publicação (CIP) \\ Biblioteca "Wanda de Aguiar Horta" \\ Escola de Enfermagem da Universidade de São Paulo}

Mosca, Natália Rodrigues

Instrumento de apoio da(o) enfermeira(o) para cuidado à família na atenção primária à saúde / Natália Rodrigues Mosca. São Paulo, 2019. $119 \mathrm{p}$.

Dissertação (Mestrado) - Escola de Enfermagem da Universidade de São Paulo.

Orientadora: Prof. ${ }^{a}$ Dr. ${ }^{a}$ Sayuri Tanaka Maeda

Área de concentração: Cuidado em Atenção Primária em Saúde

1. Cuidados de enfermagem. 2. Família. 3. Enfermagem da família. 4. Relações profissional-família. 5. Tecnologias da saúde. 6. Relações familiares. 7. Saúde da família. I. Título.

Ficha catalográfica elaborada por Fabiana Gulin Longhi Palacio (CRB-8: 7257) 
Nome: Natália Rodrigues Mosca

Título: Instrumento de apoio da (o) enfermeira(o) para o cuidado à família na atenção primária à saúde.

Dissertação apresentada ao em Saúde (MPAPS) da Escola de Enfermagem da Universidade de São Paulo para obtenção do título de Mestre em Ciências da Saúde.

Aprovado em:

\section{Banca Examinadora}

Orientadora: Prof. ${ }^{\text {a }}$ Dr. ${ }^{\text {a }}$ Sayuri Tanaka Maeda

Instituição: EEUSP

Assinatura:

Prof. ${ }^{(a)}$ Dr. ${ }^{(a)}$

Instituição:

Julgamento:

Assinatura:

Prof. ${ }^{(a)}$ Dr. ${ }^{(a)}$

Instituição:

Julgamento:

Assinatura:

Prof. ${ }^{(a)}$ Dr. ${ }^{(a)}$

Instituição:

Julgamento:

Assinatura: 


\section{DEDICATÓRIA}

À minha mãe, Cícera

Ao meu esposo, Antonio

Ao meu filho, Lucas

À minha tia, Marta

Aos meus primos, Juliana, Tatiana e Maurício 


\section{AGRADECIMENTOS}

Á Deus, por me conceder a vida, saúde e foco para poder concluir essa etapa da minha carreira acadêmica.

À minha orientadora Sayuri. Muito obrigada por todas as suas orientações, paciência e contribuições que tanto colaboraram para a construção dessa dissertação e, acima de tudo, por ter acreditado em mim.

À Dra. Flavia Maia, à Dra. Eloá Otrenti eà Dra. Anna Luiza Gryschekpelas valiosas contribuições no exame de qualificação.

À minha amada mãe, Cícera, a quem devo tudo que me tornei. Desempenhou seu papel de mãe e pai com excelência mesmo com todas as dificuldades encontradas pelo caminho. Sempre me apoiando em todas as escolhas e sendo meu braço direito nessa caminhada, por diversas vezes cuidando do meu filho para que pudesse concluir as atividades do mestrado. Meu eterno obrigada!!

Ao meu esposo, Antonio, meu grande incentivador, esteve ao meu lado em todos os momentos de dificuldade, me apoiando muito durante o processo, entendendo minhas ausências em momentos familiares para que a conclusão dessa dissertação fosse possível.

Ao meu filho, Lucas, que apesar de ser uma criança de quatro anos, se mostrou compreensivo nos momentos em que estive ausente de seus cuidados.

À minha tia Marta, que sempre foi uma segunda mãe para mim e uma segunda avó para o meu filho, sempre muito solícita e amorosa, e que, apesar das dificuldades de saúde que 
enfrenta, está sempre disposta a ajudar, com amor e boa vontade. Muito obrigada por fazer parte da nossa família.

À minha prima, Juliana que contribuiu imensamente nos cuidados com meu filho nos momentos em que tive que me ausentar para que a conclusão dessa dissertação fosse possível.

Aos meus primos, Maurício e Tatiana que, apesar de estarem do outro lado do mundo puderam contribuir com a revisão do inglês para minha dissertação.

À toda minha família, incluindo tias, primos e sogros por sempre me manterem motivada e entenderem meus momentos de ausência.

Aos meus companheiros de turma, principalmente a minha parceira Alessandra no caminhar inicial dessa pesquisa, com quem convivia profissionalmente há muitos anos, porém, com a aproximação que o mestrado nos proporcionou nesses últimos dois anos e meio, hoje é uma pessoa a qual tenho profundo aprȩ̧o, admiração e amizade.

Agradeço também à CAPES/COFEN pelo financiamento que possibilitou o desenvolvimento dessa pesquisa. 
Mosca NR. Instrumento de apoio da (o) enfermeira(o) para o cuidado à família na atenção primária à saúde [dissertação]. São Paulo: Escola de Enfermagem - Universidade de São Paulo; 2019.

\section{RESUMO}

Introdução: O Programa de Saúde da Família foi implementado em 1994 pelo Ministério da Saúde e foi inovado para o modelo Estratégia Saúde da Família vigente até hoje no primeiro nível de atenção à saúde. Os marcos são: introdução do processo saúde-doença-cuidado, trabalho organizado em equipe multidisciplinar e atenção continuada à família. Objetivos: Identificar as percepções das(os) enfermeiras (os) quanto ao instrumento proposto para o estudo como recurso para organização de cuidados de enfermagem às famílias; reestruturar o "Instrumento de apoio para elaboração do cuidado às famílias" baseado nas percepções dos participantes e no referencial teórico; discutir as potencialidades e limites do "Instrumento de apoio para elaboração do cuidado às famílias" segundo grupo de informações contidas no instrumento; apresentar o "Instrumento de apoio para elaboração do cuidado às famílias" como produto final. Percurso metodológico: Tratase de um estudo descritivo e exploratório de abordagem qualitativa. Tomou como objeto de estudo, o aprimoramento de um instrumento de cuidado às famílias na atenção primária. Originariamente portava finalidade pedagógica do curso de graduação em enfermagem. O palco da pesquisa foi em 13 unidades básicas localizadas nos Distritos de Campo Limpo e de Vila Andrade da Coordenadoria Região Sul. A seleção das participantes se deu de forma aleatória por aceitação de uma carta convite que foi enviada aos 87 profissionais possíveis participantes. Inicialmente 14 participantes demonstraram interesse, porém efetivamente permaneceram seis (6) participantes. $O$ plano de coleta de dados constituíam de fase introdutória para explicar o escopo da pesquisa, apresentação de instrumentos de coleta de perfis dos participantes e do instrumento elaborado para o cuidado às famílias. O "Instrumento de apoio para elaboração do plano de cuidado à família" havia sido readaptado visando exequibilidade na prática. De posse dos instrumentos de cuidados preenchidos, a fase sequencial foi o encontro com vistas à devolutiva das impressões e vivências na aplicação do instrumento de cuidado às famílias por meio de Grupo Focal em sessões gravadas e posteriormente, transcritas. Para análise de dados procedeu-se na categorização por temas que emergiram na interação grupal. Resultados: maioria das participantes eram especialistas em Saúde da Família com experiência profissional na área. Frente às informações coletadas foram eleitas duas categorias analíticas: a) processo de trabalho da(o) enfermeira(o) e b) contradições no sistema de organização do trabalho. A primeira foi subdividida em duas subcategorias contendo, "cuidar da família como processo e objeto" e "instrumento de cuidado à família". As categorias refletiram o reconhecimento do objeto "família "distinguindo-a de "indivíduo" no processo de cuidar. Conclusão e considerações finais: evidenciou-se como potencialidade a percepção das enfermeiras da necessidade de uma ferramenta distinta na mudança do objeto de trabalho: de cuidado individual para família. Ainda que findo como produto final desta pesquisa, visualiza-se a perspectiva de aprimoramento do mesmo no contexto da Estratégia de Saúde da Família. Produto Técnico: "Instrumento de Apoio para o Cuidado à Família" - IAPCFam.

Palavras-chaves: Cuidados de Enfermagem. Família. Enfermagem Familiar. Relações Profissional-Família. Tecnologia Aplicada aos Cuidados de Saúde. Relações Familiares. Características da Família. Saúde da Família. 
Mosca NR. Support tool for nurses in family care in basic healthcare. [dissertation]. São Paulo: Nursing School, University of São Paulo; 2019.

\begin{abstract}
Introduction: The Family Health Program was implemented in 1994 by the Ministry of Health and it was upgraded to the Family Health Strategy model, which is currently effective at the basic level of health care. The framework is: introduction of the health-illness-care process, multidisciplinary teamwork and continuous family care. Objectives: Identify the nurse's perception in regards to the proposed tool as a resource for the planning of the family care; restructure the "Support tool for preparation of family care" based on the participants' perceptions and the theoretical support; discuss the potential and limitations of the "Support tool for preparation of family care" in accordance with the information contained in it; present the "Support tool for preparation of family care" as a final product. Methodology: This is a descriptive and exploratory research of qualitative approach. The target of the research was the enhancement of a tool for family basic healthcare. Originally, it was used as a pedagogical method in the undergraduate nursing course. The sample of the research took place in 13 basic medical units located in the Districts of Campo Limpo and Vila Andrade of the South Region coordinating body. The participants were selected at random by accepting an invitation letter, which was sent to 87 potential participating professionals. Initially, 14 participants expressed interest; however, only 6 remained. The data collection plan consisted of an introductory phase to explain the scope of the research, presentation of tools profile data collection and the tool designed for family care. The "Support tool for planning the family care" was readapted targeting feasibility in the real world. Once the care tool was completed, the next phase consisted in getting feedback in a meeting focused on impressions and experiences when using the tool for family care through the Focal Group in recorded sessions, which were subsequently transcribed. The data was analyzed and categorized by subjects developed during the group sessions. Results: Most participants were specialists in family health care displaying professional experience in the subject matter. Based on the collected information, two analytical categories were selected: a) nurse's work process, and b) contradictions in the work process. The former was subdivided into two subcategories containing, "taking care of the family as a process and as an object" and "tool for family care". The categories showed a distinction between "family" and "individual" in the process of caring. Conclusion and final considerations: There was evidence that nurses notice the need of a different tool to change the work objective: from individual care to family care. However, the final result of this research, is the perception that the work objective requires an improvement in regards to the Family Health Strategy. Technical Product: "Support tool for family care" - IAPCFam.
\end{abstract}

Key Words: Nursing Care. Family. Family Nursing. Professional-Family Relationship. Technology Applied to Healthcare. Family Relationships. Family Features. Family Health. 


\section{LISTA DE SIGLAS}

$\mathrm{AB}$

ACS

APS

CAPES Coordenação de Aperfeiçoamento de Pessoal de Nível Superior

COFEN Conselho Federal de Enfermagem

CF Constituição Federal

CIT

CIB

CIPE

CIPESC Classificação Internacional das Práticas de Enfermagem em Saúde Coletiva

CRSSUL Coordenadoria Regional de Saúde Sul

CE

$\mathrm{ESF}$

ESB

GF

IBGE Instituto Brasileiro de Geografia e Estatística

IIRS Instituto Israelita de Responsabilidade Social

MPAPS Mestrado Profissional em Atenção Primária à Saúde

MS

MARE

NASF Núcleo de Atenção à Saúde da Família

NANDA North American Nursing Diagnoses Association

OSS

Organização Social de Saúde 
PSF Programa de Saúde da Família

PACS Programa dos Agentes Comunitários de Saúde

PPP Parceria Público Provada

PE Processo de Enfermagem

PNAD Pesquisa Nacional por Amostra de Domicílios

PMSP Prefeitura Municipal de São Paulo

RAS Rede de Atenção à Saúde

SUS S Sistema Único de Saúde

SES Secretaria Estadual de Saúde

SMS Secretaria Municipal de Saúde

SAE Sistematização da Assistência de Enfermagem

SIAB Sistema de Informação da Atenção Básica

STSCL Supervisão Técnica de Saúde do Campo Limpo

SBIBAE Sociedade Beneficente Israelita Brasileira Albert Einstein

TCLE Termo de Consentimento Livre e Esclarecido

UBS Unidade Básica de Saúde

USF Unidade de Saúde da Família

VD Visita Domiciliária 


\section{LISTA DE FIGURAS, QUADROS E GRÁFICOS}

Figura 1 - Representação da área de abrangência das unidades de saúde da SBIBAE........45

Quadro 1 - Estruturação da oficina introdutória para os profissionais participantes na pesquisa. São Paulo - SP, 2019.

Quadro 2 - Perfil dos profissionais participantes em idade, tempo de formação, curso de especialização/residência em saúde da família, tempo de atuação como enfermeira(o) na ESF e tempo de trabalho na equipe atual. São Paulo - SP, 2019. . .56

Quadro 3 - Quadro de síntese das evidências das potencialidades e limites do Instrumento de Apoio para elaboração do Plano de Cuidado à Família. São Paulo - SP, 2019. 56

Gráfico 1 - Pirâmide etária da população coberta pela ESF nos distritos de Campo Limpo e Vila Andrade, São Paulo - SP, 2019.

Gráfico 2 - Representação da população por escolaridade, nos distritos de Campo Limpo e Vila Andrade, São Paulo - SP, 2019.

Gráfico 3 - Situação no mercado de trabalho referida pela população, nos distritos de Campo Limpo e Vila Andrade, São Paulo - SP, 2019.

Gráfico 4 - Condições e situação de saúde referidas pela população, nos distritos de Campo Limpo e Vila Andrade, São Paulo - SP, 2019. 


\section{SUMÁRIO}

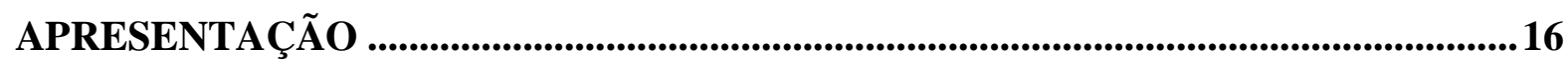

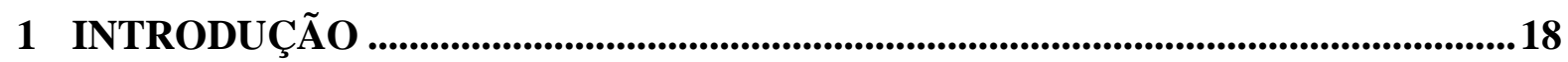

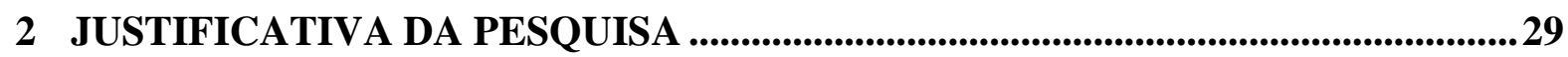

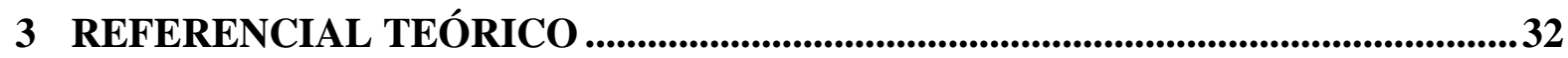

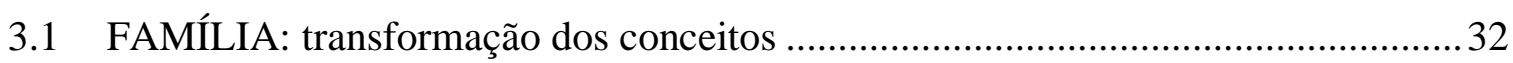

3.2 PROCESSO DE TRABALHO DO ENFERMEIRO: sua evolução e inserção na

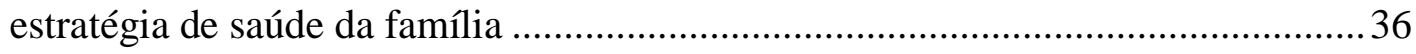

4 OBJETIVOS ................................................................................................................................41

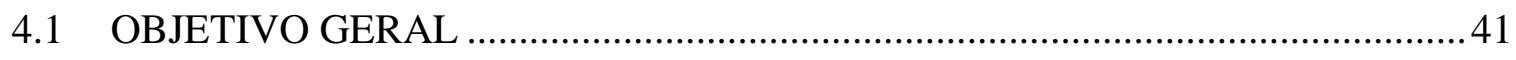

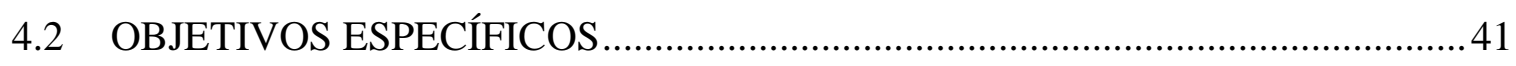

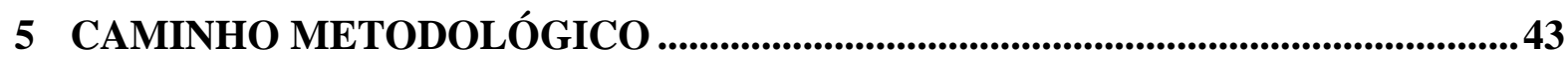

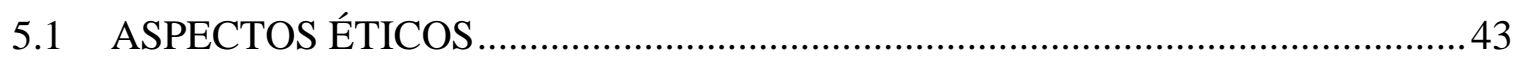

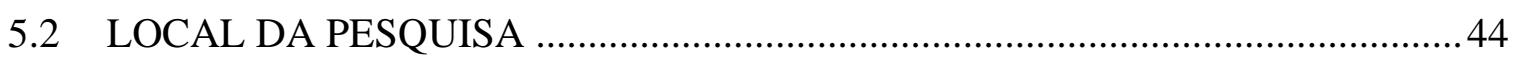

5.3 SUJEITOS DA PESQUISA ............................................................................

5.4 INSTRUMENTO DE COLETA DE DADOS ……………………………….......4

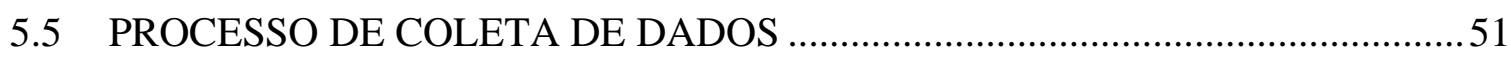

5.5.1 A escolha pelo grupo focal ..................................................................... 51

5.5.2 Etapas da pesquisa.............................................................................

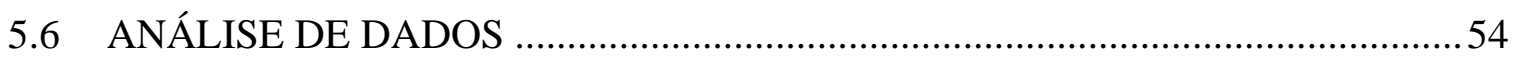

6 RESULTADOS E DISCUSSÃO _........................................................................56

7 CONSIDERAÇÕES FINAIS.....................................................................................................70

REFERÊNCIAS...............................................................................................................73

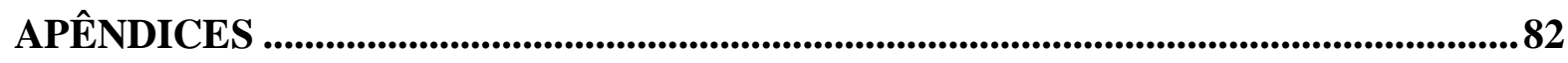

APÊNDICE 1 - TERMO DE CONSENTIMENTO LIVRE E ESCLARECIDO -

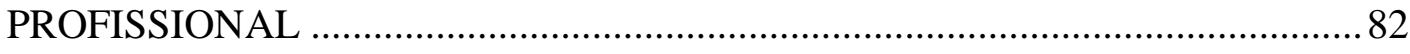

APÊNDICE 2 - TERMO DE CONSENTIMENTO LIVRE E ESCLARECIDO - 
APÊNDICE 3 - INSTRUMENTO DE APOIO PARA ELABORAÇÃO DO PLANO DE CUIDADO À FAMÍLIA (ADAPTADO). 86

APÊNDICE 4 - MATERIAL DE APOIO PARA CONSULTA ………………………....... 88

APÊNDICE 5 - CARACTERIZAÇÃO DO PROFISSIONAL.........................................90

APÊNDICE 6 - PRODUTO TÉCNICO: INSTRUMENTO DE APOIO PARA O CUIDADO À FAMÍLIA - IAPCFAM. 91

APÊNDICE 7 - MATERIAL DE APOIO PARA CONSULTA FINALIZADO................94

APÊNDICE 8- QUADRO DE DISCURSOS CATEGORIZADOS .................................96

ANEXOS......................................................................................................................................................100

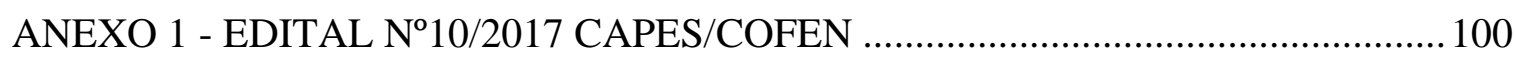

ANEXO 2 - CARTA DE APROVAÇÃO DO CEP/USP ......................................... 108

ANEXO 3 - CARTA DE APROVAÇÃO DO CEP/SMS ............................................ 111

ANEXO 4 - INSTRUMENTO ORIGINAL DA EEUSP ........................................... 115 
APRESENTACÃO 


\section{APRESENTAÇÃo}

Graduei-me como enfermeira pela Faculdade de Enfermagem do Hospital Israelita Albert Einstein. As crianças e neonatos foram, à princípio, meu foco de atenção em cuidados de enfermagem. Contudo, ingressei na Saúde da Família, no ano de 2012, como enfermeira de uma equipe de Saúde da Família em uma Unidade Básica de Saúde da região Sul de São Paulo.

Permaneci nessa posição por quatro anos. Surgiu, então, um convite para ocupar uma posição de trabalho de natureza de apoio técnico às unidades básicas de saúde, da Secretaria de Saúde da Prefeitura do município de São Paulo, administradas pela entidade contratada: Sociedade Beneficente Israelita Brasileira “Albert Einstein”.

Neste período, minha principal atuação foi exercer a função de profissional de referência em saúde da criança e do adolescente para toda a equipe de Estratégia de Saúde da Família (ESF) em Saúde da População Negra da região Sul do Município. Além disso, participava do processo seletivo e da capacitação de profissionais da enfermagem. Operava em atividades de vigilância em saúde relativas à cobertura de produtos imunobiológicos à população. Como atividade de avaliação, assumi a elaboração de relatórios de gestão, em consonância com as metas de coberturas vacinais e de produção vigentes no contrato da parceria entre o HIAE e a prefeitura de São Paulo.

Durante minha trajetória profissional dentro da ESF, evidenciou-se para mim a importância e a efetividade do desenvolvimento de ferramentas de trabalho para a resolução de problemas.

Nesse sentido, o compromisso relacionado à Sistematização da Assistência de Enfermagem do Edital EE nº/2017 CAPES/ COFEN veio ao encontro de meus anseios profissionais de ampliar o conhecimento e contribuir para melhoria do trabalho em equipe e, consequentemente, impactar a qualificação do cuidado em saúde. 
1 INTRODUCÃO 


\section{INTRODUÇÃO}

O reconhecimento da importância do cuidado da família, e não somente do indivíduo, consolida-se após a criação do Sistema Único de Saúde (SUS) por meio da Constituição Federal de 1988 (CF-88) e da promulgação das Leis Orgânicas de Saúde, n. ${ }^{\circ}$ 8.080/90 e 8.142/90, que versam sobre as condições para a organização e o funcionamento dos serviços relativos à promoção, proteção e recuperação da saúde e dispõem sobre a participação da comunidade na gestão do SUS, detalhando o funcionamento do sistema e instituindo preceitos que são seguidos até a atualidade. A partir dessas legislações, ficou estabelecido que cada esfera de governo, além de organizar e manter Conselhos de Saúde, teria de realizar conferências nessa área com periodicidade de quatro anos. A primeira conferência realizada a partir da Lei Orgânica foi a 9a Conferência Nacional de Saúde, no ano de 1992, que, sob a temática "Municipalização é o caminho", teve como temas centrais "sociedade, governo e saúde", "implantações do SUS" e “controle social", permeando assim a ideia de um processo de distribuição de poderes e decisões de natureza técnica. (Brasil, 2009; Brasil, 2010a).

A criação do SUS e a promulgação das Leis Orgânicas de Saúde são acontecimentos que tiveram por finalidade reduzir a situação de desigualdade na assistência à saúde da população, tornando obrigatório o atendimento público a qualquer cidadão que necessitasse de cuidados em saúde, sem distinção de cor, raça, ou condição social, sendo proibidas cobranças de dinheiro sob qualquer pretexto. No período anterior a CF-88, o sistema público de saúde prestava assistência apenas aos trabalhadores vinculados à Previdência Social, que na época totalizavam, aproximadamente, 30 milhões de pessoas com acesso aos serviços hospitalares, restando aos demais cidadãos o atendimento oferecido por entidades filantrópicas. (Brasil, 2009; Brasil, 2010a).

Em 2011, o decreto 7.508 regulamenta a Lei Orgânica de Saúde e institui o Contrato Organizativo de Ação Pública (COAP), fortalecendo determinados aspectos relacionados à gestão do SUS e promovendo, assim, um avanço no que se refere à definição da organização de serviços de saúde em redes, ao padrão de integralidade, ao fortalecimento da governança regional, ao reforço aos instrumentos de planejamento, além de produzir inovação em termos de contratualização (Brasil, 2011a).

No Brasil, a origem do Programa de Saúde da Família (PSF) remonta à criação do Programa de Agentes Comunitários de Saúde (PACS) em 1991. Esses programas convergem 
com os debates e análises referentes ao processo de mudança do paradigma que orienta o modelo de atenção à saúde vigente desde a década de 1970. Como parte do processo de reforma do setor da saúde, tais propostas como a ESF e PACS, assim como a $9^{\text {a }}$ Conferência Nacional de Saúde, atuam de forma reorganizadora e visam aumentar a acessibilidade ao sistema de saúde por meio de ações de prevenção e promoção da saúde, recolocando a Atenção Primária a Saúde (APS) no sistema de saúde. (Brasil, 2010a).

O SUS é um dos maiores e mais complexos sistemas público de saúde do mundo, abrangendo desde o simples atendimento para avaliação da pressão arterial até o transplante de órgãos, garantindo acesso integral e universal para toda a população do país. Com a sua criação, o SUS proporcionou o acesso universal ao sistema público de saúde, sem discriminação. A atenção integral à saúde, e não somente aos cuidados assistenciais, passou a ser um direito de todos os brasileiros, desde a gestação e por toda a vida, com foco na saúde com qualidade de vida, visando a prevenção e a promoção da saúde. (Brasil, 2019b; Programa Saúde da Família, 2000).

No âmbito federal, a CF-88 determina a composição do SUS pelo Ministério da Saúde (MS) que, considerado o gestor nacional do SUS, formula, normatiza, fiscaliza, monitora e avalia as políticas e as ações do sistema, em articulação com o Conselho Nacional de Saúde (CNS) que atua no âmbito da Comissão Intergestores Tripartite (CIT) para pactuar o Plano Nacional de Saúde (PNS) (Brasil, 1988; 2019b).

Na esfera estadual, Estados, juntamente com as Secretarias Estaduais de Saúde (SES), são responsáveis por participar da formulação das políticas e ações de saúde e devem prestar apoio aos municípios em articulação com o Conselho Estadual de Saúde (CES) e participar da Comissão Intergestores Bipartite (CIB) para aprovar e implementar o Plano Estadual de Saúde (PES) (Brasil, 2019b).

A nível municipal, os municípios, com as Secretarias Municipais de Saúde (SMS), planejam, organizam, controlam, avaliam e executam as ações e serviços de saúde em articulação com o Conselho Municipal de Saúde (CMS) e a esfera estadual para aprovar e implantar o Plano Municipal de Saúde (Brasil, 2019b).

Em 1994, o MS lançou o PSF como política nacional de atenção básica, visando, como estratégia setorial, a reorientação do modelo assistencial brasileiro, com caráter organizativo e substitutivo, fazendo frente ao modelo tradicional de assistência primária baseada em profissionais médicos especialistas. (Programa Saúde da Família, 2000).

O PSF que se consolidou como estratégia prioritária para a reorganização da Atenção Básica (AB) no Brasil e o governo emitiu a Portaria $N^{\circ}$ 648, de 28 de março de 2006, na qual 
ficava estabelecido que o PSF é a estratégia prioritária do Ministério da Saúde para organizar a Atenção Básica, que tem como um dos seus fundamentos possibilitar o acesso universal e contínuo a serviços de saúde de qualidade, reafirmando os princípios básicos do SUS: universalização, igualdade, descentralização, integralidade e participação da comunidade, mediante o cadastramento do território adscrito e a vinculação dos usuários (Brasil, 2007).

Essa portaria foi revogada em 2011 por meio da apresentação de uma nova proposta: a $\mathrm{n}^{\circ}$ 2.488/2011, documento que estabelece a revisão de diretrizes e normas para a organização da AB e aprova a Política Nacional de Atenção Básica para a Estratégia Saúde da Família (ESF) e para o PACS. É importante notar que se promove nesse momento uma significativa reformulação em relação à denominação inicial: o "Programa de Saúde da Família" passa a ser reconhecido como "Estratégia de Saúde da Família" por não se tratar mais apenas de um "programa", neste momento então, surge a ideia de rede de atenção à saúde (RAS), a descentralização, as atribuições dos profissionais da ESF, a infraestrutura das UBS e o reforço do cuidado centrado na família (Brasil, 2011b).

Para que cumpra com seu propósito, a ESF necessita de diretrizes que apoiem as diferentes atividades a ela relacionadas. Sua estratégia central é a definição do território adscrito procurando reorganizar o processo de trabalho em saúde mediante operações intersetoriais e ações de promoção, prevenção e atenção à saúde, permitindo os gestores, profissionais e usuários do SUS compreender a dinâmica dos lugares e dos sujeitos (individual e coletivo) desvendando, assim, as desigualdades sociais e as iniquidades em saúde para melhor distribuição dos esforços de saúde direcionado pelo nível de complexidade de cada caso. (Figueiredo, 2012).

É importante ressaltar que a compreensão de que os cuidados dispensados na $\mathrm{AB}$ são "simples" há muito deixou de ser realidade. Sabe-se que estes são complexos e precisam dar conta das necessidades de saúde da população, em nível individual e coletivo, de forma que as ações contribuam para a saúde e autonomia das pessoas e na determinação de saúde da comunidade. Nesse sentido, torna-se evidente que a AB é a porta de entrada da população aos serviços de saúde e que cabe a ela a centralizar a gestão do cuidado da população adscrita em seu território (Figueiredo, 2012).

Visando a garantia de atendimento à população, o setor público estabeleceu parcerias por meios de contratos ou convênios de prestação de serviços ao Estado com o setor privado, de forma a assumir a administração de unidades públicas, por meio de Organizações Sociais de Saúde (OSS) ou Parecerias Público Privadas (PPP) (Morais et al., 2018). 
As OSS surgiram no Brasil na esteira das possibilidades abertas para a gestão pública, após a Reforma do Estado desencadeada nos anos de 1994 e 1995. Portanto, são consideradas como um dos padrões de apresentação do denominado "terceiro setor" e emergem como nova modalidade voltada à função social de gestão e provisão de serviços de saúde, vinculadas ao modelo das PPP (Morais et al., 2018).

As Leis federais n ${ }^{\circ}$ 9.637/1998e a Lei Complementar do Estado de São Paulo n ${ }^{\circ}$ 846/1998, qualificam como OSS “pessoas jurídicas de direito privado, sem fins lucrativos, cujas atividades sejam dirigidas à saúde, à assistência social, ao ensino, à pesquisa e à cultura". (Brasil, 1998a; São Paulo, 1998).

A formulação e publicação da Lei n ${ }^{\circ}$ 9.637/1998 serviu de base para as publicações subsequentes das leis subnacionais, que tiveram como marco orientador a definição de OSS proposta pelo Ministério da Administração Federal e Reforma do Estado (MARE), entendida como um modelo de organização pública não estatal destinado a absorver atividades "publicizáveis" mediante qualificação específica, tratando-se de uma parceria entre o Estado e a sociedade e baseada em resultados de desempenho (Brasil, 1997).

Em São Paulo, onde está centralizado o seio desta pesquisa, a OSS é o modelo adotado desde 1998, pelo qual o Estado transfere a execução de serviços em equipamentos públicos de algumas áreas para entidades privadas sem fins lucrativos, previamente qualificadas pelo Poder Público. Essa administração é feita mediante um contrato de gestão que define indicadores de produção, de qualidade e metas a serem alcançadas, como o número de consultas, de visitas domiciliárias, acompanhamento de pré-natal, entre outros (Fiore, Duarte, 2014).

Com a implantação da ESF como estratégia de reorganização do SUS e implantação dos seus princípios, cada equipe de saúde conhece a realidade das famílias pelas quais é responsável, por meio do cadastramento e da identificação de suas características. Dessa forma, a proximidade da equipe de saúde com o usuário permite a criação de vínculos terapêuticos, garante maior adesão ao tratamento, proporcionando-lhes abordagem integral e mobilizando os recursos e apoios necessários ao atendimento dos problemas e necessidades de saúde do indivíduo, família e comunidade. Sempre que necessário, deve-se assegurar a referência da rede básica de saúde para as unidades da rede especializada, buscando garantir a integralidade da atenção (Silva, et al, 2011).

A ESF é composta por uma equipe multiprofissional que dispõe, no mínimo, de médico generalista ou especialista em saúde da família ou médico de família e comunidade, enfermeiro generalista ou especialista em saúde da família, auxiliar ou técnico de enfermagem e agentes comunitários de saúde (ACS) (Brasil, 2019a). 
O número de ACS deve ser suficiente para cobrir $100 \%$ da população cadastrada, com um máximo de 750 pessoas por agente e de 12 ACS por equipe de Saúde da Família, não ultrapassando o limite máximo recomendado de pessoas por equipe (Brasil, 2019a).

Cada equipe de Saúde da Família deve ser responsável por, no máximo, 4.000 pessoas de uma determinada área, que passam a ter corresponsabilidade no cuidado com a saúde. Também há uma equipe de Saúde Bucal (ESB), composta por cirurgião-dentista generalista ou especialista em saúde da família, auxiliar e/ou técnico em Saúde Bucal (Brasil, 2019a).

Entendendo que a realidade do território é complexa e necessita de um olhar multifacetado em que diferentes profissionais possam apoiar a inserção da ESF na RAS, garantindo a continuidade e a integralidade da atenção, foram criados os Núcleos de Apoio à Saúde da Família (NASF), compostos por profissionais de diferentes áreas de conhecimento que atuam de maneira integrada com as equipes da ESF (Brasil, 2010b).

Esse novo modelo de atenção que é a ESF tem como principais características: (i) basear-se nas premissas da Atenção Primária à Saúde (APS) e do SUS; (ii) adotar uma noção mais ampliada do processo saúde doença; (iii) possuir uma equipe multiprofissional com atuação interdisciplinar; e (iv) ter como objeto de trabalho o ser humano com carência de saúde na sua integralidade, em seu contexto familiar, cultural e social. Esse novo modelo de atenção se contrapõe ao então tradicional modelo de saúde, que estava baseado nas premissas da biomedicina, pautando o entendimento de saúde como ausência de doença, com uma prática centrada no médico, na doença e na cura. O modelo da ESF prevê uma responsabilização integral para a atenção às necessidades de saúde do conjunto da população. Essa nova proposta gera resultados assistenciais diferenciados ao incorporar um novo conjunto de ações de saúde, no âmbito individual e coletivo, incluindo promoção, proteção, prevenção, diagnóstico, tratamento, reabilitação, redução de danos e manutenção da saúde. O tratamento e a cura não são mais o centro da assistência e sim o indivíduo, a família e a comunidade (Soratto et al., 2015).

O processo saúde-doença-cuidado é resultante do modo de produzir e reproduzir dos indivíduos, sendo um conjunto de interações de diferentes aspectos; políticos, econômicos, sociais e culturais, que se apresentam em agravos de saúde e afetam diretamente os indivíduos e suas famílias. Dessa forma, o resultado da interação entre agentes e contextos será sensível a aspectos sociais e históricos em diferentes espaços e tempos. Esse enfoque, no campo da saúde, recorre ao materialismo histórico dialético para explicar como fatores de naturezas diversas, presentes na sociedade, podem contribuir, positiva ou negativamente para definir o estado de saúde e problemas de populações (Gondim, 2011). 
Para atender então ao modelo proposto pela ESF, compreender o processo saúde-doença e as necessidades de saúde, é fundamental que o enfermeiro da ESF possa fazer uma melhor escuta das pessoas que buscam "cuidados em saúde", tomando suas necessidades como centro de suas intervenções e práticas. Tornou-se um desafio aqui conseguirmos fazer uma conceituação de necessidades de saúde que pudesse ser apropriada e implementada pelos trabalhadores de saúde nos seus cotidianos. Algo que nos permitisse fazer uma mediação entre a incontornável complexidade do conceito necessidades de saúde e sua compreensão e apropriação pelos trabalhadores, visando a uma atenção mais humanizada e qualificada (Pinheiro, Mattos, 2011).

As necessidades de saúde são compreendidas como naturais, necessárias e alienadas. São necessidades naturais porque se referem à conservação e à perpetuação da vida, incluindo as necessidades de alimentação, de abrigo, de contato social e sexual e de cooperação. Já as necessidades necessárias envolvem a liberdade, a autorrealização, a autonomia, a autodeterminação, a atividade moral e a reflexão. Por sua vez, as necessidades alienadas são próprias do sistema capitalista e estão relacionadas a dinheiro, poder e posse de objetos. Nessa perspectiva, a autora conclui que, todo trabalho humano tem como finalidade a satisfação de necessidades (Heller, 1986).

No âmbito da Saúde Coletiva, compreende-se que as necessidades de saúde são geradas no contexto das relações que os seres humanos estabelecem entre si para se reproduzirem como sujeitos e como sociedade. Identificar e atender as necessidades de saúde significa também reconhecer em indivíduos, famílias e grupos/classes sociais de uma área definida tais necessidades, com a finalidade de subsidiar um melhor planejamento e execução das ações, promovendo uma melhor gestão do serviço (Campos, Soares, 2013).

Diante do exposto, o trabalho no cuidado com as famílias é evidentemente complexo, pois necessita da compreensão de conceitos como família e necessidades de saúde, do seu funcionamento sistêmico e na construção de vínculo entre o profissional e o grupo familiar. Para o cuidado com as famílias, é necessário o engajamento em uma relação de colaboração mútua, que tenha enfoque tanto no tratamento, na administração dos problemas e nas doenças da família, como na prevenção de doenças e na promoção da saúde (Campos, 2009).

Para auxiliar a(o) enfermeira(o) na delimitação de um plano de cuidados direcionado à família, tomaremos como referência o processo de Sistematização da Assistência de Enfermagem (SAE), que é considerada uma importante ferramenta de gestão do cuidado, pois fornece subsídios para a organização do trabalho da(o) enfermeira(o). Dentre as suas vantagens, destaca-se a elevação da qualidade da assistência de enfermagem, o que beneficia tanto o 
paciente, por meio de um atendimento individualizado, quanto a(o) enfermeira(o), mostrando a importância do processo de enfermagem (PE) para a organização da assistência de enfermagem. (Cunha, Barros, 2005; Leite de Barros, Lopes 2010; Oliveira et al., 2012).

Para que a(o) enfermeira(o) possa tomar as decisões de maneira correta, tem de se basear em conhecimentos científicos, intensificando o pensamento crítico e o raciocínio clínico. Conhecimentos e procedimentos teoricamente organizados, sistematizados e sempre reformulados, constituem-se uma base segura para a ação eficiente. Entende-se que a aplicação de uma assistência de enfermagem sistematizada é a única possibilidade da(o) enfermeira(o) atingir sua autonomia e constitui a essência de sua prática profissional (Leite de Barros, Lopes 2010).

O PE que hoje é o método utilizado para realizar a SAE no Brasil teve sua conceituação histórica iniciada em meados de 1919. Trata-se de um método utilizado para a tomada de decisões apoiado em passos científicos e organizado em cinco etapas inter-relacionadas, interdependentes e recorrentes, a saber: (i) a coleta de dados ou histórico, (ii) o diagnóstico de enfermagem, (iii) o planejamento, (iv) a implementação e (v) a avaliação. (Leite de Barros, Lopes 2010; Miranda et al., 2013; Ribeiro, 2004).

O PE tem por diferença essencial do método de solução de problemas ser proativo, destacando-se a necessidade de investigação contínua dos fatores de risco e de bem-estar, mesmo quando não houver problemas aparentes. Então, deve existir de forma inequívoca a intenção e consciência em reconhecer o objeto de trabalho, para que a transformação do indivíduo, família e comunidade possam acontecer e para que se tenha um produto. Essa condição poderá proporcionar a(o) enfermeira(o) o desenvolvimento do trabalho sustentado por modelos de cuidados, que o levará a utilizar o pensamento crítico, formando a base para a tomada de decisão (COREN-SP, 2015).

Um dos aspectos discutidos dentro da SAE é a padronização da linguagem utilizada na etapa dos diagnósticos de enfermagem. Assim, para suprir tais necessidades, nas décadas de 1970 e 1980 começam a aparecer as primeiras classificações, especialmente indicadas pela associação norte-americana de diagnósticos de enfermagem (North American Nursing Diagnoses Association - NANDA). Posteriormente, na década de 1990, temos o início da Classificação Internacional das Práticas de Enfermagem (CIPE), que, mais adiante, deu origem à Classificação Internacional das Práticas de Enfermagem em saúde coletiva (CIPESC), cujos princípios estão em consonância com os do SUS. Entretanto, ambas as taxonomias trabalham com a resposta humana a um agravo de saúde, ao risco que ele traz, à vulnerabilidade, aos processos de vida e à promoção da saúde, abrangendo não somente o indivíduo, como também 
a família e a comunidade (Cubas, Nóbrega, 2015; Leite de Barros, Lopes 2010; NANDA-I, 2018; Ribeiro, 2004; São Paulo, s.d.).

A aplicabilidade da SAE ainda é incipiente. Em especial, no que diz respeito à SAE na ESF, alguns autores apontam a forma insuficiente como as famílias são atendidas, quando considerada a relação cuidado versus abordagem. Observam-se, a partir de então, diferentes formas de abordagens familiar no cenário da ESF, tais como: família/indivíduo; família/domicílio; família/indivíduo/domicílio; família/comunidade; família/risco social; família/família. Estar preparado para conseguir atuar nos diferentes cenários é de grande importância na prática da(o) enfermeira(o) da ESF, pois é a partir dessa abordagem mais ampla que se consegue cuidar não somente do indivíduo como também do todo ao qual ele pertence. (Buss, Pelegrini-Filho, 2007; Gomes, Pereira, 2005; Ribeiro, 2004).

Estudos têm demonstrado que a implementação da SAE e do PE na APS ocorre de forma bastante fragmentada e incipiente, e que as(os)s enfermeiras(os) relacionam o PE a uma atividade burocrática, resultante de um distanciamento entre o pensar e o fazer, entre a teoria e a prática, principalmente por não haver preocupação maior com a qualidade da assistência e sim com a demanda do serviço, e quando implementada na sua concepção, afasta mais do que aproxima a(o) enfermeira(o) do paciente/família (Neves, Shimizui, 2010; Peduzzi, Anselmi, 2002).

Entre os fatores que impedem os profissionais de colocar a SAE em prática, destacamse os seguintes: a pouca valorização do profissional, a descontinuidade do processo, a burocracia, a falta de capacitação, as condições inadequadas do serviço, a complexidade na formulação do diagnóstico, a redução de profissionais com elevada quantidade de pacientes gerando uma sobrecarga no serviço e os impressos insuficientes. Note-se, portanto, que as principais causas apontadas para a não execução da SAE estão relacionadas às condições inadequadas de trabalho (Silva et al., 2011).

Um estudo desenvolvido em um hospital de grande porte em Pernambuco evidenciou que as(os) enfermeiras(os) desejam praticar todas as fases da SAE, mas que não conseguem fazê-lo por encontrarem no percurso uma série de fatores que distanciam a teoria da prática, o que acaba por desmotivar o profissional que, apesar de reconhecer a relevância da sistematização, não a experimenta de fato. Compreende-se, dessa forma, que embora o processo seja considerado e indicado como "implementado", o que se percebe na prática é uma forma parcial de se trabalhar, com a realização de uma ou outra etapa (Silva et al., 2011).

De maneira análoga, outra pesquisa aponta para as dificuldades da implementação e da operacionalização da SAE e identificou que a maior dificuldade encontrada é o pouco 
conhecimento das(os) enfermeiras(os) sobre o conceito da sistematização da assistência. Nesse caso, apesar de os profissionais reconhecerem a melhoria da qualidade da assistência como principal consequência da realização da SAE, não a executam na prática, justificando seu comportamento como uma tentativa de implementar fases isoladas do processo, quando, na realidade, não se pode falar em sistematização se todas as fases não forem implantadas conjuntamente, visto que as etapas que a compõem são interdependentes. Além disso, as(os) enfermeiras(os) parecem não compreendem a SAE como um conjunto de ações relacionadas que conduzem a um resultado, mas como um impresso destinado ao registro de atitudes isoladas de algumas etapas do processo (Lanssoni, 2008).

Outras dificuldades ressaltadas pelos profissionais para a operacionalização da SAE é a falta de impresso específico para o registro. Entretanto, o autor evidencia que a documentação da SAE não necessita de impresso próprio, pois ela pode ser registrada no prontuário do paciente para a contemplação de toda a equipe de saúde e a valorização da enfermagem como profissão que merece reconhecimento científico (Lanssoni, 2008). Cabe ressaltar que o diagnóstico de enfermagem é considerado como uma das etapas mais complexas, o que colabora para que haja muitas divergências na sua realização. Quando se amplia o olhar para a APS, essa dificuldade fica ainda mais perceptível pois não há uma universalidade nas técnicas de classificação utilizadas, encontrando o profissional taxonomias diversas como as já descritas anteriormente: NANDA, CIPE e CIPESC (Silva et al., 2011).

Na Europa, um estudo realizado em Portugal testou um instrumento para avaliação e intervenção familiar para enfermeiras(os) que teve como base as etapas do PE e evidenciou que o uso do instrumento foi útil na prática dos seus enfermeiros, provendo compreensão e reciprocidade entre os profissionais e as famílias, servindo como base para a identificação dos pontos fortes da família, possibilitando ajustar as intervenções as suas necessidades. Nesse estudo, também foi evidenciado pelas(os) enfermeiras(os) a necessidade de mudanças nos sistemas de informação, pois consideram que a documentação da assistência favorece o planejamento e assegura a continuidade dos cuidados de enfermagem, de maneira que houve a estruturação do sistema de registro baseado no modelo de cuidados à família proposto. Após essa reestruturação, ocorreu a avaliação do impacto na mudança dos cuidados de enfermagem, o que demonstrou uma concepção multidimensional da saúde da família como um estado dinâmico e a superação do espectro individual para a família (Figueiredo, 2009).

Diante do exposto e, pela escassez de literatura neste sentido, fica claro que as(os) enfermeiras(os), seja no âmbito hospitalar ou da APS, conhecem a SAE e a consideram importante para a qualificação do cuidado, mas esse conhecimento é insuficiente para a 
aplicação de uma sistematização de qualidade para o paciente e/ou família. Nesse sentido, ter um instrumento embasado no raciocínio clínico da(o) enfermeira(o) da ESF para sistematização do cuidado prestado às famílias nos serviços de saúde contribuirá significativamente para a tomada de decisão e assertividade na abordagem familiar. 


\section{JUSTIFICATIVA DA PESQUISA}




\section{JUSTIFICATIVA DA PESQUISA}

Em virtude da complexidade do objeto proposto para o estudo (família), além das diferenças culturais na interpretação e concepção sobre família na literatura, visualiza-se uma necessidade de instrumentalização do processo de abordagem com as famílias no momento de atuação das equipes de ESF nos diferentes territórios, para que as(os) enfermeiras(os) direcionem o melhor cuidado para as famílias sob seus cuidados. Diante disso, a proposta é produzir um instrumento de forma a balizar as ações de sistematização de cuidado às famílias pela ESF, respeitando as normativas estabelecidas segundo a Política Nacional da Atenção Básica (Brasil, 2017). No cenário real, persistem as modalidades de ações de foco individual e, consequentemente, a instância familiar sofre prejuízos na escala de atenção. Acredita-se que a contradição existente no cuidado com foco no indivíduo dentro da ESF decorre da dinâmica das conjunturas técnicas, políticas e econômicas advindas das instâncias governamentais acatadas por Organizações Sociais mediadas por termos de contratos e convênios que buscam praticar o conteúdo das decisões.

Essas adversidades fazem parte da realidade, contudo há demandas políticas positivas que abrem perspectivas para a superação. Reconhecendo a extensa capacidade de atuação do profissional enfermeiro, cabe a ele analisar a realidade do paciente e sua família como um todo. Para tanto, a presente proposta de reestruturar e apresentar uma ferramenta capaz de ampliar o cuidado da(o) enfermeira(o) da ESF para a família apresenta-se como uma oportunidade para melhorar o desempenho na prática.

A Coordenação de Aperfeiçoamento de Pessoal de Nível Superior (CAPES), em parceria com o Conselho Federal de Enfermagem (COFEN), formularam um edital n. ${ }^{\circ}$ 27/2016 (Anexo 1) em apoio a Programas de Pós-Graduação da Área de enfermagem - Modalidade Mestrado Profissional, do qual este projeto faz parte, visando formar recursos humanos de enfermagem e desenvolver pesquisas científicas e tecnológicas, com foco na Sistematização da Assistência de Enfermagem com abordagem familiar.

O presente projeto propõe-se, então, a apresentar como produto final o "Instrumento de apoio para elaboração do cuidado às famílias", a ser utilizado pelo enfermeiro, extensivo à equipe de enfermagem, com a finalidade de reconhecer os benefícios bem como limites deste instrumento visando a profissionalização do cuidado no contexto da ESF. 
Desse modo, tem-se a seguinte pergunta como questão central deste projeto: o Instrumento de apoio para elaboração de plano de cuidado à família é potente para auxiliar o enfermeiro da ESF na organização do cuidado à família? 


\section{REFERENCIAL TEÓRICO}

\subsection{FAMÍLIA: transformação dos conceitos}

Acredita-se que o conceito de família deve sustentar e influenciar diretamente os aspectos relacionados às abordagens familiares na ESF, razão pela qual buscar explicitar este conceito é fundamental para melhor compreender as práticas que acontecem neste cenário (Silva, et al, 2011).

A palavra latina "gens", utilizada para designar um grupo de consanguíneos, significa linhagem ou descendência. Desse modo, "gens" caracteriza um grupo que constitui uma descendência comum e que está unido por certas instituições sociais ou religiosas, formando uma comunidade particular. Estudos discorrem longamente acerca das relações entre membros humanos desde tempos remotos, e indicam que um grupamento de pessoas não cultivava, originalmente, o sentido de parentalidade. Observou-se nestas obras a singular descrição de "propriedade" relacionada à conformação da noção de "família", refletindo o interesse de proteção ao patrimônio particular, ou seja, a emergência dominante da dimensão econômica, vinculando à figura do homem a questão da herança e a paulatina conexão de poder do Estado como mediador (Engels, 2017; Morgan, 2004).

O termo "família" é derivado do latim famulus, que significa "escravo doméstico". Este termo foi criado na Roma antiga do século VIII a.C. para designar um novo grupo social que surgiu entre as tribos latinas, cujo chefe mantinha sob seu poder a mulher, os filhos e certo número de escravos, com o pátrio poder romano e o direito de vida e morte sobre todos eles. (Engels, 2017; Scarre, 1995).

O conceito de família tem se modificado de acordo com as transformações dos modos de produção social, havendo variações culturais dentro do mesmo modo de produção, na mesma época histórica, subjacentes às interferências dadas pelas diferentes culturais que compõem a formação social considerada (Egry, Fonseca, 2000; Engels, 2017; Itaboraí, 2015).

Inicialmente, a família era constituída unicamente pelo casamento, não havendo nenhum outro meio de constituição familiar, como a união estável. Como consequência de tais fatos, a figura do divórcio era inimaginável, vez que a felicidade dos membros não era mais importante do que a predominância da família como instituição, afinal, o divórcio representaria 
uma quebra no poderio econômico concretizado pelo casamento. Tal ideia de família é tida como inconcebível atualmente pela maior parte das pessoas, sendo, de certo modo, repudiada na atualidade. Porém, tal modificação se deu somente pela evolução pela qual passou a sociedade ao lutar pela igualdade entre os indivíduos e pela valorização da dignidade da pessoa humana, conquistas estas que se encontram estabelecidas hoje em nosso mais alto regramento jurídico, a CF-88 (Brasil, 1988).

Nesse documento, a família é:

Art. 226. A família, base da sociedade, tem especial proteção do Estado.

$\S 3^{\circ}$ - Para efeito da proteção do Estado, é reconhecida a união estável entre o homem e a mulher como entidade familiar, devendo a lei facilitar sua conversão em casamento. $\S 4^{\circ}$ - Entende-se, também, como entidade familiar a comunidade formada por qualquer dos pais e seus descendentes. pouco importando a existência, ou não, de casamento entre os genitores.

Conforme um dos dicionários de Língua Portuguesa mais populares no Brasil, considera-se como família:

[...] Conjunto de todos os parentes de uma pessoa, e, principalmente, dos que moram com ela;

Conjunto formado pelos pais e pelos filhos;

Conjunto formado por duas pessoas ligadas pelo casamento e pelos seus eventuais descendentes;

Conjunto de pessoas que têm um ancestral comum;

Conjunto de pessoas que vivem na mesma casa (Ferreira, 2010).

No âmbito cristão, a família é um elemento de muita importância para Deus, sendo considerada como uma "instituição sagrada, criada por Ele". De acordo com essa perspectiva, quando o homem foi criado, Deus viu que não era bom que ele estivesse sozinho, e por isso criou a mulher para ser sua companheira. Juntos, eles receberam a ordem de se multiplicar e povoar a Terra. Mais tarde, foi dito que o homem que se casasse deveria sair da sua casa, deixando pai e mãe, para se tornar um com a sua esposa. Após a criação do primeiro casal, a Bíblia fala sobre muitas famílias. Gênesis 12 diz que por meio da família de Abraão, todas as famílias da terra seriam abençoadas (Bíblia, 2008).

$\mathrm{Na}$ concepção sociológica, a família é um grupo auto identificado de dois ou mais indivíduos, cuja associação é caracterizada por termos especiais, que podem ou não estar relacionados a linhas de sangue ou legais, mas que funcionam de modo a se considerarem uma família". Pode-se verificar semelhantes elementos de caracterização na definição "família uma comunhão interpessoal de amor", na qual no "interpessoal" há uma menção a pessoas 
interagindo, na "comunhão" está o significado do compromisso entre estas pessoas e no "amor" encontra-se a base da associação (Bruschini, 1989; Wernet, Angelo, 2003).

Do ponto de vista antropológico, aprofunda-se a análise na dinâmica de relacionamento familiar e isto se mantém como aspecto importante até hoje. Essa noção será enriquecida compreendendo que a família é um complexo sistema de organização - com crenças, valores e práticas desenvolvidas e ligadas diretamente às transformações da sociedade - em busca da melhor adaptação possível para a sobrevivência de seus membros e da instituição como um todo. O sistema familiar muda à medida que a sociedade muda, e todos os seus membros podem ser afetados por pressões internas e externas, fazendo com que ela se modifique e se adapte no sentido de assegurar a continuidade e o crescimento psicossocial de seus membros (Faco, Melchiori, 2009; Minuchin 1985).

Na prática, em UBS, o Sistema Informação da Atenção Básica (SIAB) adota o seguinte conceito de família baseado na abordagem do Instituto Brasileiro de Geografia e Estatística (IBGE):

“... conjunto de pessoas ligadas por laços de parentesco, dependência doméstica ou normas de convivência que residem na mesma unidade domiciliar. Inclui empregado(a) doméstico(a) que reside no domicílio, pensionistas e agregados" (Brasil. 1998b).

A fonte IBGE* fornece um panorama extenso de dados úteis para apreensão das características gerais da população, componentes da dinâmica demográfica e estatísticas vitais por regiões. Depreende-se que tomam como unidades de leitura, a família e o domicílio, ou seja, local de habitação. Além do conceito sobre família, o banco de dados disponibiliza informações sobre estruturas familiares e seus padrões de organização (famílias reconstituídas, casais do mesmo sexo, casais que moram separados, crianças com dupla residência, famílias monoparentais e pessoas que moram sozinhas) e os ciclos de vida familiar (considerando a presença de crianças e jovens de diferentes faixas etárias, idosos e a participação de membros adultos no mercado de trabalho). Outro aspecto de utilidade prática são as informações quanto a unidades domésticas em que se descreve e classifica a estrutura física de domicílios habitados por famílias.

Essa riqueza e amplitude das informações sobre famílias oferecidas pelo IBGE pode nos auxiliares a compreender a descrição formulada para o instrumento proposto:

\footnotetext{
*Instituto Brasileiro de Geografia e Estatística - IBGE. População [Internet]. Brasília. [citado 2017 jul. 28]. Disponível em: https://www.ibge.gov.br/estatisticas/sociais/populacao.html
} 
[....] são instituições com várias características, dentre elas laços de parentesco e normas de relacionamento que determinam direitos e obrigações de várias espécies. Como a convivência entre os membros pode oscilar em intensidade, as famílias podem variar bastante em composição e organização. A depender da forma como são estabelecidas na sociedade, as normas de convivência podem manter fortemente relacionados parentes de gerações e colinearidades distantes ou ainda limitar a relação mais intensa aos parentes. Essa relação consiste, dentre outras coisas, de uma divisão de trabalho e recursos entre os membros da família (Bruschini, Ridenti, 1994).

Sobre esse aspecto, para Bruschini e Ridenti (1994), aqueles que exercem as atividades econômicas no interior ou fora do domicílio revelam que o local de habitação pode ser uma entidade de moradia, acrescida de espaço para trabalhos autônomos ou informais, cujos ganhos adicionais representariam sustentos vitais para determinadas famílias.

Ademais, o conceito de família da Pesquisa Nacional por Amostra de Domicílios (PNAD) tenta refletir uma unidade que compartilha rendas e consumo de bens duráveis e nãoduráveis dentro de um domicílio e está fortemente ligado ao modelo conhecido como "família nuclear" (casal com filhos) e suas variações (sem cônjuge, sem filhos, com outros parentes e não-parentes vinculados) (IBGE, s.d.).

A identificação de características relacionadas ao modelo de família nuclear e suas variações é uma grande virtude dos dados do IBGE, mas pode gerar algumas classificações controversas. Algumas são especialmente importantes porque estão relacionadas às principais mudanças ocorridas na composição dos arranjos domiciliares brasileiros, como, por exemplo, o crescimento dos arranjos familiares ao grupo de habitantes de um mesmo domicílio. Nelas a família estudada geralmente refere-se à organização formada por um conjunto de pessoas com quaisquer laços reconhecidos de parentesco. Com as mudanças econômicas, políticas, sociais e culturais ocorridas ao longo dos tempos, a sociedade foi obrigada a reorganizar regras básicas para amparar a nova ordem familiar (IBGE, s.d.).

Acredita-se que decodificar a organização das informações disponibilizadas pelo IBGE facilita a compreensão dos cenários de práticas comumente encontrados no campo de exercício de cuidados à saúde da população por permitir relacionar aspectos gerais fornecidos pelo banco de dados às particularidades de cada área ${ }^{\dagger}$ Neste sentido, não causa estranhamento adotá-lo como uma das principais fontes de referência para conformar dados de dimensão familiar na prática de Saúde da Família. Entretanto, salienta-se que sempre haverá enfoques conceituais específicos a depender dos problemas enfrentados (IBGE, s.d.).

Em face à evolução social, não há como ter uma visão estagnada e unívoca do que da noção de família. Para este estudo, acolhemos a abordagem de família segundo o IBGE, e 
consequentemente o SIAB, e se propõe associá-las às concepções sociológicas e antropológicas de acordo com a realidade enfrentada. (IBGE, s.d.).

Acredita-se que para que a(o) enfermeira(o) assista à família é necessário conhecer o funcionamento, os fatores que influenciam as suas experiências na saúde e na doença e o sentido da assistência à família. Entender a Saúde da Família como estratégia de mudança significa repensar práticas, valores e conhecimentos de todos os grupos envolvidos no processo de produção social da saúde, respeitando suas culturas (Faco, Melchiori, 2009).

\subsection{PROCESSO DE TRABALHO DO ENFERMEIRO: sua evolução e inserção na estratégia de saúde da família}

O SUS, para se tornar efetivo como sistema, depende do nível da atenção primária, cujo foco é a promoção e a prevenção de agravos, que precisava ser fortalecida de maneira que a maior parte das demandas apresentadas fossem resolvidas (Brasil, 2012; Elias et al., 2006).

O cuidado em saúde, do ponto de vista ético, é a sua razão de ser. Incorpora um modo humano de agir que considera os conhecimentos e habilidades profissionais (Zoboli, Fracolli, Chiesa, 2013). A compreensão do cuidado é definida como "esforços transpessoais de ser humano para ser humano no sentido de proteger, promover e preservar a humanidade, ajudando as pessoas a encontrarem o significado na doença, no sofrimento e na dor, bem como na existência" (Zoboli, Fracolli, Chiesa, 2013). O cuidado em saúde coletiva é um processo que se transformou historicamente, relacionando-se as formas de organização e de produção de vida social. Os profissionais de saúde que atuam em saúde coletiva precisam encontrar mediações técnicas, procedimentos, instrumentos e condições organizacionais e processos de trabalho que levem à concretização do cuidado (Zoboli, Fracolli, Chiesa, 2013).

A conformação de um saber técnico-científico específico da área ocorreu no decorrer da institucionalização da enfermagem como profissão. A primeira forma organizada do saber na enfermagem é constituída pelas técnicas de enfermagem, posteriormente pela sistematização dos princípios científicos que as fundamentam e mais recentemente pela busca de construção de teorias. Este inerente saber técnico, que fundamenta as ações de enfermagem no exercício cotidiano do trabalho, constitui o cuidado de enfermagem como objeto de trabalho (Peduzzi, Anselmi, 2002).

O trabalho é caracterizado como um processo de transformação que ocorre porque o homem tem necessidades que precisam ser satisfeitas. Outra característica importante a ser 
lembrada é sua intencionalidade, ou seja, o trabalho depende de uma construção prévia, de um projeto que o homem traz em mente desde o início do processo (Gonçalves, 1992). Transpondo essa concepção teórica ao âmbito da enfermagem, tem-se que os objetos de trabalho são o cuidado de enfermagem e o gerenciamento do cuidado. Particularmente, o cuidado de enfermagem está sendo concebido como "um conjunto de ações de acompanhamento contínuo do usuário/população, no decorrer de doenças ou ao longo de processos socio-vitais, visando a promoção, prevenção e recuperação da saúde" (Peduzzi, 2000).

Tendo em vista a divisão dos objetos de trabalho de enfermagem citados anteriormente, cuidado de enfermagem e gerenciamento do cuidado, pode considerar aqui as diferentes categorias da profissão, sendo que o cuidado de enfermagem direto fica a cargo do auxiliar e/ou técnico de enfermagem e o gerenciamento do cuidado remetido à enfermeira(o) (Peduzzi, 2000).

No que diz respeito ao processo de trabalho da(o) enfermeira(o) dentro da ESF, visualiza-se um amplo campo de atuação, no qual a(o) enfermeira(o) assume um papel essencial de agente articulador das ações desenvolvidas pelas equipes na ESF (Ferreira, Périco, Dias, 2018).

Dentre as atividades atribuídas à(o) enfermeira(o) na ESF pelo MS, destacam-se a assistência integral aos indivíduos, famílias e comunidades, que consiste em realizar os cuidados diretos de enfermagem, e a consulta de enfermagem, que prevê a solicitação de exames complementares e a prescrição de medicações. Cabem, ainda, ao enfermeiro o acompanhamento e a promoção da capacitação dos ACS e auxiliares de enfermagem e a corresponsabilidade em planejar, gerenciar, coordenar, executar e avaliar as atividades da Unidade de Saúde da Família (USF). Nessa perspectiva, pode-se afirmar que o processo de trabalho desse profissional conjectura cinco dimensões, complementares e interdependentes: assistência, gerência, ensino, pesquisa e participação política (Brasil, 2011b).

A dimensão do processo de trabalho de assistência tem como objeto o cuidado, que advém da demanda dos indivíduos, das famílias, dos grupos sociais, das comunidades e da coletividade. Na dimensão do processo de trabalho de gestão, a(o) enfermeira(o) faz uso de ferramentas específicas e tem como objetos a organização do trabalho e os recursos humanos de enfermagem. Em relação à dimensão do ensino, considera-se neste estudo o foco formar, capacitar e aperfeiçoar recursos humanos da saúde e ensinar e orientar indivíduos, família e comunidades. Já na dimensão pesquisa, a(o) enfermeira(o) atua de forma a repensar o fazer profissional, identificando novas formas de desenvolver suas ações na busca da construção do 
conhecimento. A dimensão política é simbolizada pela força de trabalho de enfermagem e sua representação social (Paula, et al., 2014; Sanna, 2007).

Dentro do processo de trabalho da(o) enfermeira(o) da ESF, a menor unidade de cuidado é a família, sendo o indivíduo parte de um contexto familiar. Conhecer aspectos como a estrutura da família, sua composição, a organização e a interação dos membros entre si e com o ambiente, os problemas de saúde, as situações de risco e os padrões de vulnerabilidade é vital para o planejamento do cuidado à família. Podemos obter essas informações mediante a utilização de algumas ferramentas na saúde da família que nos possibilitam o levantamento de dados para a estruturação e organização da assistência à saúde da população (Mello et al., 2005).

Uma vez fixada como objeto de cuidado a unidade familiar, tanto a(o) enfermeira(o) como todos os profissionais que integram a equipe multidisciplinar na ESF dispõe de algumas ferramentas que objetivam estreitar as relações entre profissional e família, proporcionando a compreensão da realidade vivenciada pelo indivíduo e suas relações com a família e a sociedade (Alves, Gasparello, 2015; Chapadeiro, Okano, Araújo, 2011; Cubas, Nóbrega, 2015).

Dentre as diversas ferramentas disponíveis, cabe elencar nesse estudo três que são essenciais para que a(o) enfermeira(o) consiga se aproximar e compreender a realidade das famílias assistidas por eles: ciclo de vida familiar, genograma e ecomapa.

Em relação à primeira, tem-se que o Ciclo de Vida familiar pode ser entendido como "uma série de eventos previsíveis que ocorrem dentro das famílias como resultado das mudanças em sua organização” (Alves, Gasparello, 2015; Cubas, Nóbrega, 2015). Vale lembrar, que essa ferramenta não se refere às etapas de desenvolvimento humano (infância e velhice), sendo denominada como "ciclos de vida" por entender que os sistemas familiares têm uma história própria, passam por transformações e se desenvolvem em etapas específicas, consistindo em oito estágios de desenvolvimento, a saber: (i) saída de casa, (ii) compromisso com seu parceiro/a, (iii) aprendizado para a vida junto, (iv) chegada do primeiro filho, (v) vida com pré-escolares, (vi) vida com adolescentes, (vii) saída dos filhos e (viii) velhice. Em cada uma dessas fases, a família passa por ajustes e adaptações. Nas configurações familiares atuais, algumas dessas fases podem não acontecer ou coexistirem em um único momento. (Alves, Gasparello, 2015; Cubas, Nóbrega, 2015). Em todos os estágios, a família e a interação de seus membros interferem no processo saúde-doença de seus integrantes. Deste modo, essa ferramenta visa trabalhar com a previsibilidade de doenças e sua utilização possibilita o planejamento de medidas preventivas (Alves, Gasparello, 2015; Cubas, Nóbrega, 2015).

Como mencionado anteriormente, a segunda e terceira ferramentas que possibilitam uma atenção centrada na família são o genograma e ecomapa, recursos que, citados por diversos 
autores, têm por finalidade a representação gráfica da estrutura familiar. Sua elaboração inclui, além da família nuclear, as relações que sejam determinantes à saúde-doença. Como características básicas, o genograma identifica a estrutura da família e suas relações, as doenças incidentes e prevalentes, repetições no padrão de relacionamento e os conflitos que vinculam o processo de adoecimento. Já o ecomapa possibilita estender os mesmos padrões para avaliação das relações familiares para o ambiente onde ela está inserida (Alves, Gasparello, 2015; Chapadeiro, et al, 2011; Cubas, Nóbrega, 2015; Mendes, 2012).

Um estudo sobre terminologias observou que a assistência de enfermagem está direcionada, mesmo na saúde coletiva, à sistematização do atendimento individual, voltada a atenção aos grupos prioritários com o enfoque de risco biológico: hipertensos, diabéticos, crianças em creches, entre outros. Isso mostra a importância de se concretizar um instrumento que possibilite a(o) enfermeira(o) da ESF direcionar o foco da sistematização do seu trabalho para a instituição familiar. (Cubas, Egry, 2008).

A Portaria n. ${ }^{\circ}$ 2.436, de 21 de setembro de 2017, define que a organização do trabalho em ESF é realizada por uma equipe multiprofissional. Entretanto, no presente trabalho, o instrumento foi direcionado para uma das categorias da equipe, o(a) enfermeiro(a), buscando articulação com o Edital EE n. ${ }^{\circ}$ 10/2017 (Anexo I). Esse aspecto será oportunamente retomado nas considerações finais (Brasil, 2017). 


\section{OBJETIVOS}

\subsection{OBJETIVO GERAL}

Reconhecer as potencialidades e os limites do "Instrumento de apoio para elaboração do cuidado às famílias", na prática da(o) enfermeira(o) da ESF, para organizar o cuidado à família.

\subsection{OBJETIVOS ESPECÍFICOS}

$\checkmark$ Identificar as percepções das(os) enfermeiras(os) quanto ao instrumento proposto para o estudo como recurso para organização de cuidados de enfermagem às famílias na ESF;

$\checkmark$ Reestruturar o "Instrumento de apoio para elaboração do cuidado às famílias" com base nas percepções dos participantes e no referencial teórico;

$\checkmark$ Discutir as potencialidades e os limites do "Instrumento de apoio para elaboração do cuidado às famílias” segundo grupo de informações contidas no instrumento;

$\checkmark$ Apresentar o "Instrumento de apoio para o cuidado às famílias" como produto final. 


\section{CAMINHO METOdOLÓGICO}

Trata-se de um estudo descritivo e exploratório, de abordagem qualitativa, que buscou aprimorar um instrumento já existente de cuidado às famílias na atenção primária. Como processo metodológico, contou-se com a colaboração dos enfermeiros da ESF na aplicação desse instrumento e sequencialmente, em colaboração com as enfermeiras participantes, discutiram-se os aspectos relevantes como conceitos de família, necessidades de saúde e SAE por meio de grupo focal, sobre questões inerentes às mudanças segundo a vivência prática dessas profissionais e o referencial teórico.

\subsection{ASPECTOS ÉTICOS}

Este estudo foi conduzido em conformidade com a Resolução do Conselho Nacional de Saúde-CNS 510/2016 que dispõe sobre as normas aplicáveis a pesquisas em Ciências Humanas e Sociais cujos procedimentos metodológicos envolvam a utilização de dados diretamente obtidos com os participantes ou de informações identificáveis ou que possam acarretar riscos maiores do que os existentes na vida cotidiana .

Inicialmente, o projeto foi submetido à anuência da Prefeitura do Município de São Paulo, às instâncias da Supervisão Técnica de Saúde do Campo Limpo (STSCL) onde obteve concordância no que concerne à realização da pesquisa. A etapa seguinte foi a da Coordenadoria Regional de Saúde Sul (CRSSUL) que demandou tempo para ajustes no projeto.

Em seguida, foi submetido ao Comitê de Ética em Pesquisa da Escola de Enfermagem da USP conforme Resolução do CNS 466/12 em maio de 2018. Até sua aprovação final, decorreram mais seis meses de investimento (Anexo 2). Posteriormente obteve a apreciação do Comitê de Ética da Secretaria Municipal da Saúde da Prefeitura do município de São Paulo (Anexo 3).

Após a aprovação do projeto pelos Comitês de Ética e Pesquisa da EEUSP e da SMS, o projeto foi dividido em duas pesquisas distintas, sobre o direcionamento de duas pesquisadoras.

A participação dos profissionais nesta pesquisa foi de forma voluntária, sendo aplicados os Termo de Consentimento Livre e Esclarecido (TCLE), assim como as famílias que aceitaram ser submetidas à aplicação do "Instrumento de apoio para elaboração do cuidado às famílias" por exigência do CEP. (Apêndices 1 e 2). 


\subsection{LOCAL DA PESQUISA}

O Município de São Paulo é composto por 453 UBS, mais de 1300 equipes de ESF e 123 equipes de NASF, e está organizado em cinco Coordenadorias de Saúde, às quais estão vinculadas as Supervisões Técnicas de Saúde, conforme prevê o plano de regionalização municipal (São Paulo, 2017; Seade, 2018).

Selecionou-se a Coordenadoria Regional Sul de Saúde como local de estudo, onde está inserida a Subprefeitura Campo Limpo, responsável por uma área de 36,7 km2. A decisão pela escolha foi em virtude da familiaridade das pesquisadoras com a área geográfica, o que possibilitava uma comunicação mais fluida e mais direta com a Supervisão e Coordenação Técnica de Saúde, além de fácil acesso devido ao vínculo empregatício da pesquisadora com a Sociedade Beneficente Israelita Brasileira Albert Einstein (SBIBAE).

O local selecionado compõe-se de Distritos de Saúde do Campo Limpo (218.758 habitantes), Capão Redondo (268.481 habitantes) e Vila Andrade (143.008 habitantes). A população aproximada é de 650.000 habitantes, o que representa $28,3 \%$ da população residente na Coordenadoria de Saúde Sul. A taxa de urbanização é de $100 \%$ e a densidade demográfica média é de 17.486,65 hab./km2 (São Paulo, 2017; Seade, 2018).

Em agosto de 2001, a Secretaria Municipal da Saúde da Prefeitura do Município de São Paulo firmou o convênio junto à SBIBAE como uma das instituições parceiras para gestão dos recursos de saúde para atividades de coordenação, implantação e desenvolvimento do PSF no município de São Paulo, atualmente ESF. Em 2008, houve ampliação incluindo equipes de saúde bucal (ESB) e NASF nesta área.

A ESF, em consonância com as Diretrizes da Política Nacional da Atenção Básica (Portaria n. ${ }^{\circ}$ 648-MS de 28/03/2006) Cada equipe , é composta por 1 médico, 1 enfermeiro, 2 auxiliares de enfermagem e 5 ACS. Nesta composição, também estão previstas equipes de saúde bucal, com cirurgião dentista, auxiliar e técnico de saúde bucal, e equipes de NASF, compostas por multiprofissionais como médico psiquiatra, psicólogo, fisioterapeuta, educador físico, terapeuta ocupacional e psicólogo podendo haver variações de acordo com a necessidade do território (São Paulo, 2013).

Esta parceria entre Secretaria Municipal de Saúde da Prefeitura do Município de São Paulo (SMS/PMSP) e SBIBAE está firmada por meio de um termo de convênio, a partir do qual se prevê que o Instituto Israelita de Responsabilidade Social (IIRS) gerencia treze (13) 
Unidades Básicas de Saúde, com oitenta e sete (87) equipes de saúde da família que prestam assistência a uma população de 361.766 habitantes desta região.

O IIRS é um dos pilares de atuação da SBIBAE e faz parte de um dos seus eixos de trabalho a gestão de unidades de saúde da Atenção Primária em Parceria Público Privada com a SMS/PMSP na zona sul, nas regiões de Campo Limpo e Vila Andrade (São Paulo, 2017).

Figura 1 - Representação da área de abrangência das unidades de saúde da SBIBAE

\section{Área de abrangência}
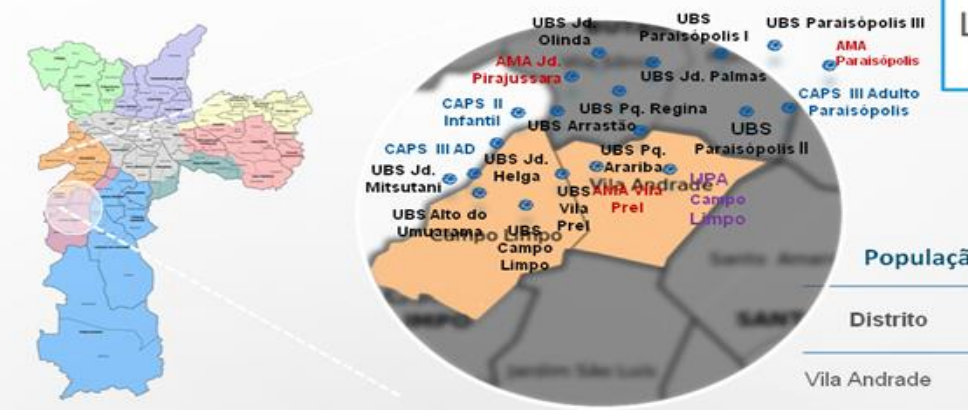

$75 \%$ da população de Vila Andrade e Campo Limpo é cadastrada nas UBS da SBIBAE

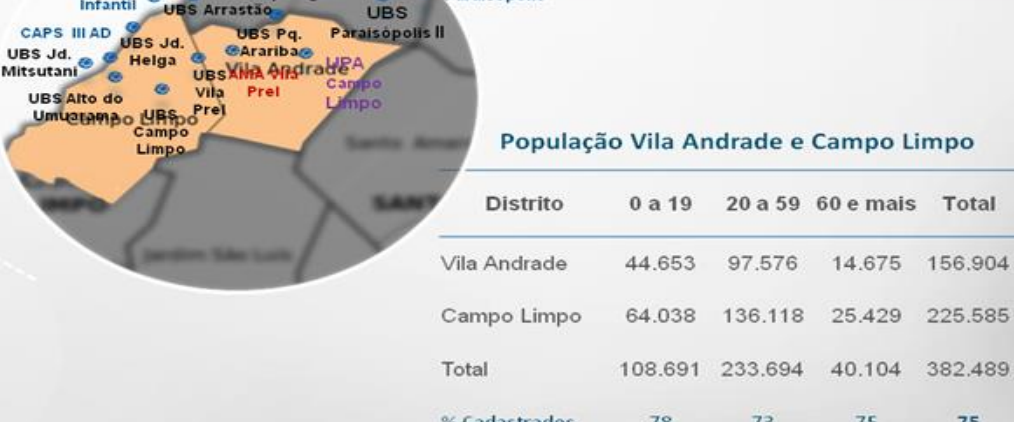

$\%$ Cadastrados $\begin{array}{llll}78 & 73 & 75 & 75\end{array}$ Fonte: Fundaç̧̃o SEADE, 2018

Fonte: Arquivos do Núcleo de Sistemas de Informação do Hospital Israelita Albert Einstein.

Os dois distritos escolhidos apresentam forte desigualdade, sendo o Campo Limpo mais periférico em relação à Vila Andrade. Entretanto, a Vila Andrade compreende uma das áreas mais nobres do Município, onde se concentram famílias de alto poder aquisitivo, contrastando com uma grande população carente que vive nas inúmeras comunidades das proximidades. Nesse distrito, localiza-se o bairro de Paraisópolis e estima-se que vivam ali cerca de 80 mil pessoas e 17.730 domicílios. tornando esta comunidade a segunda maior da cidade de São Paulo, sendo menor somente que a conhecida comunidade de Heliópólis (São Paulo, 2017).

Abaixo, segue alguns indicadores sócio demográficos que melhor retratam o perfil desta população. 
Gráfico 1 - Pirâmide etária da população coberta pela ESF nos distritos de Campo Limpo e Vila Andrade, São Paulo - SP, 2019.

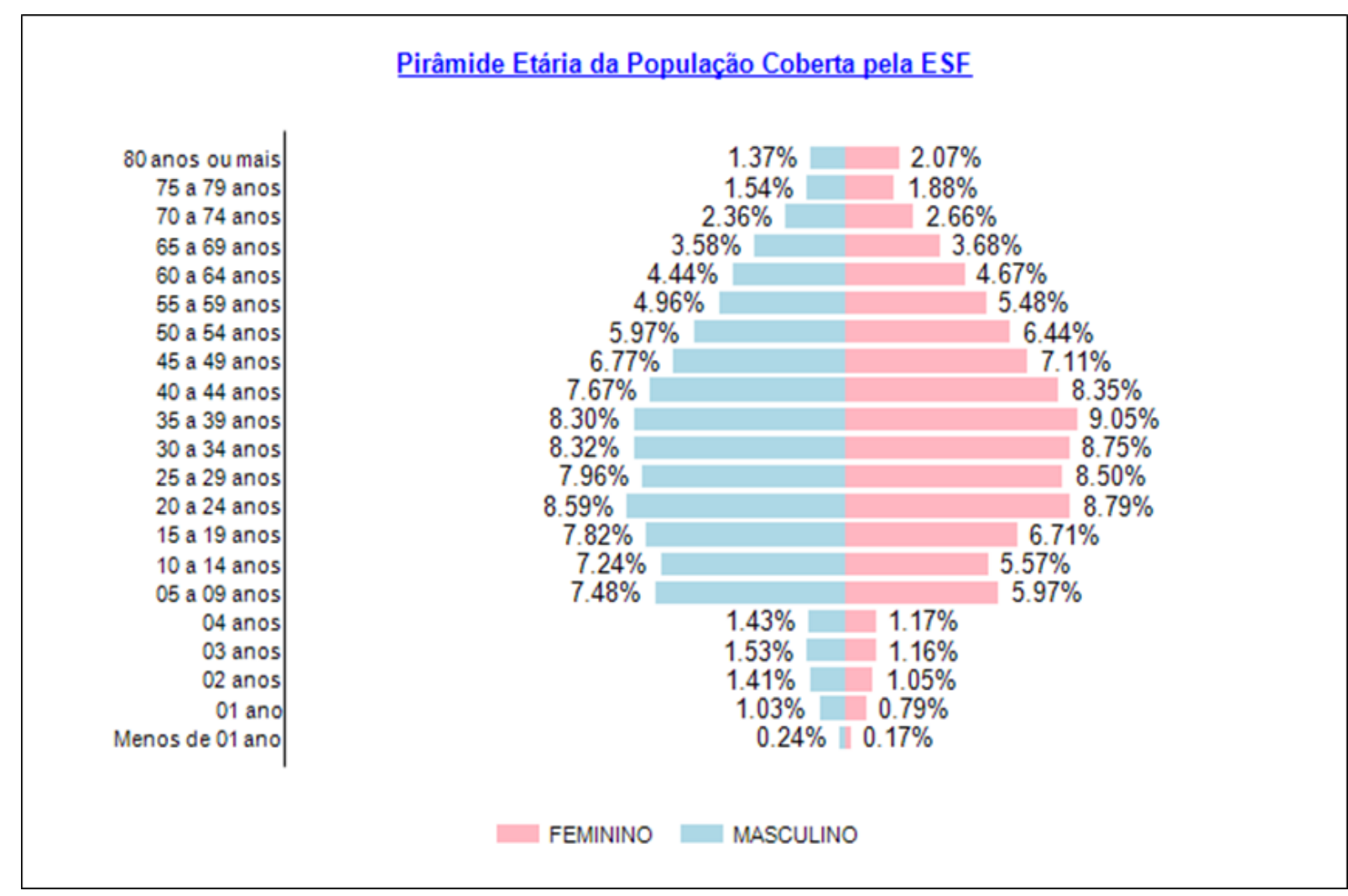

Fonte: Cadastro E-SUS

Gráfico 2 - Representação da população por escolaridade, nos distritos de Campo Limpo e Vila Andrade, São Paulo - SP, 2019.

\begin{tabular}{|c|c|c|}
\hline \multicolumn{3}{|c|}{ Escolaridade } \\
\hline Superior, aperfeiçoamento, especialização, mestrado, doutorado - & \multicolumn{2}{|r|}{$8.97 \%$} \\
\hline Pré-escola (exceto CA) - & $2.23 \%$ & \\
\hline Nenhum- & $4.05 \%$ & \\
\hline Ensino médio, médio $2^{\circ}$ ciclo (cientifico, técnico e etc) $-f$ & & $16.60 \%$ \\
\hline Ensino médio especial - & $3.52 \%$ & \\
\hline Ensino médio EJA(supletvo) - & $2.87 \%$ & \\
\hline Ensino fundamental especial - & $0.34 \%$ & \\
\hline Ensino fundamental EJA - séries iniciais (supletivo $1^{2} \mathrm{a} 4^{\mathrm{a}}$ ) - & $1.31 \%$ & \\
\hline Ensino fundamental EJA - séries finais (supletivo $5^{2}$ a $8^{5}$ ) - & $1.88 \%$ & \\
\hline Ensino fundamental completo- & \multicolumn{2}{|r|}{$12.82 \%$} \\
\hline Ensino fundamental $5^{2}$ a $8^{2}$ séries - & \multicolumn{2}{|r|}{$22.42 \%$} \\
\hline Ensino fundamental $1^{2}$ a $4^{2}$ séries - & \multirow{2}{*}{\multicolumn{2}{|c|}{$18.01 \%$}} \\
\hline Creche- & & \\
\hline Classe de alfabetização - CA- & $1.26 \%$ & \\
\hline Alfabetização para adultos (Mobral, etc) - & $0.19 \%$ & \\
\hline
\end{tabular}

Fonte: cadastro E-SUS 
Gráfico 3 - Situação no mercado de trabalho referida pela população, nos distritos de Campo Limpo e Vila Andrade, São Paulo - SP, 2019.

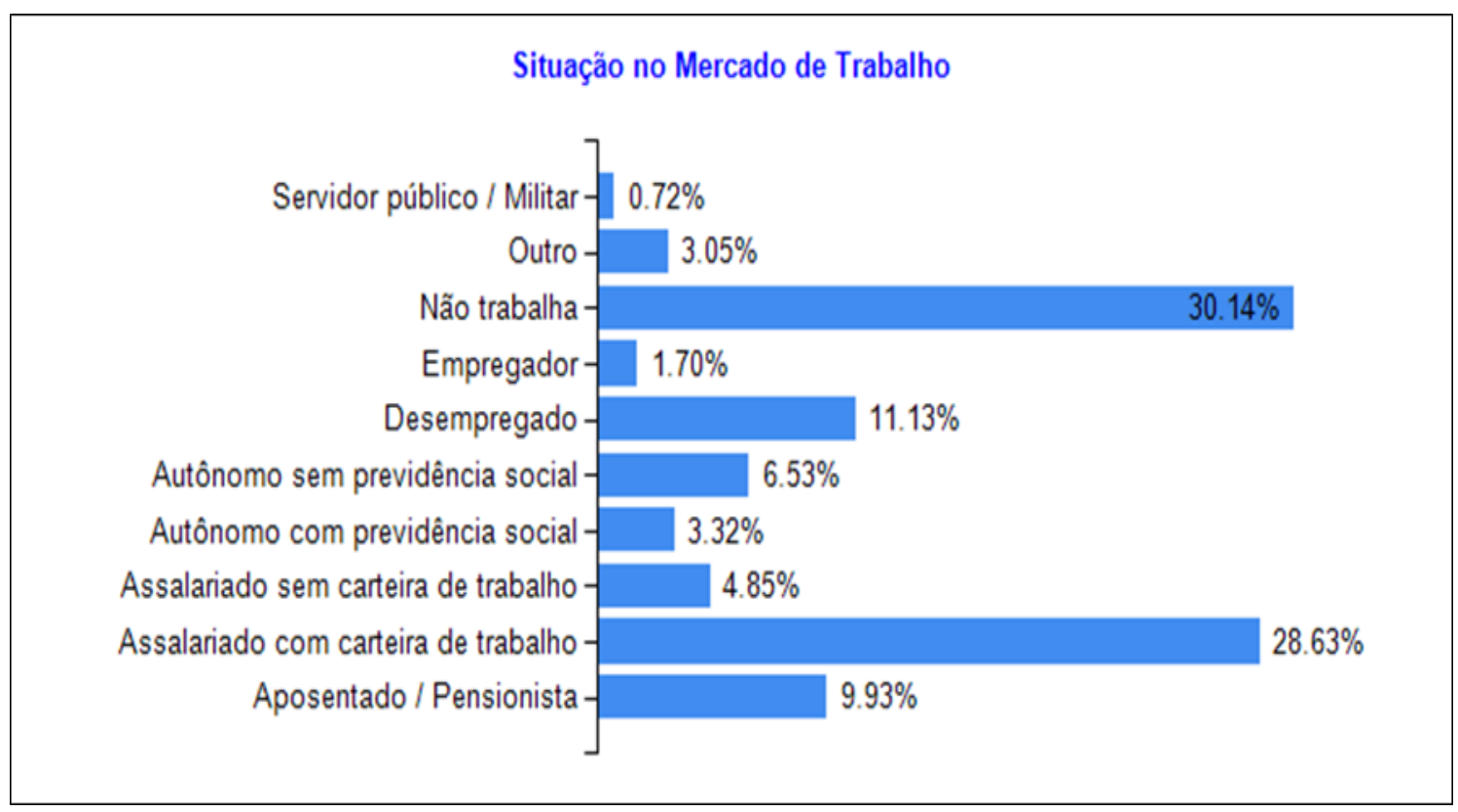

Fonte: Cadastro E-SUS

Gráfico 4 - Condições e situação de saúde referidas pela população, nos distritos de Campo Limpo e Vila Andrade, São Paulo - SP, 2019.

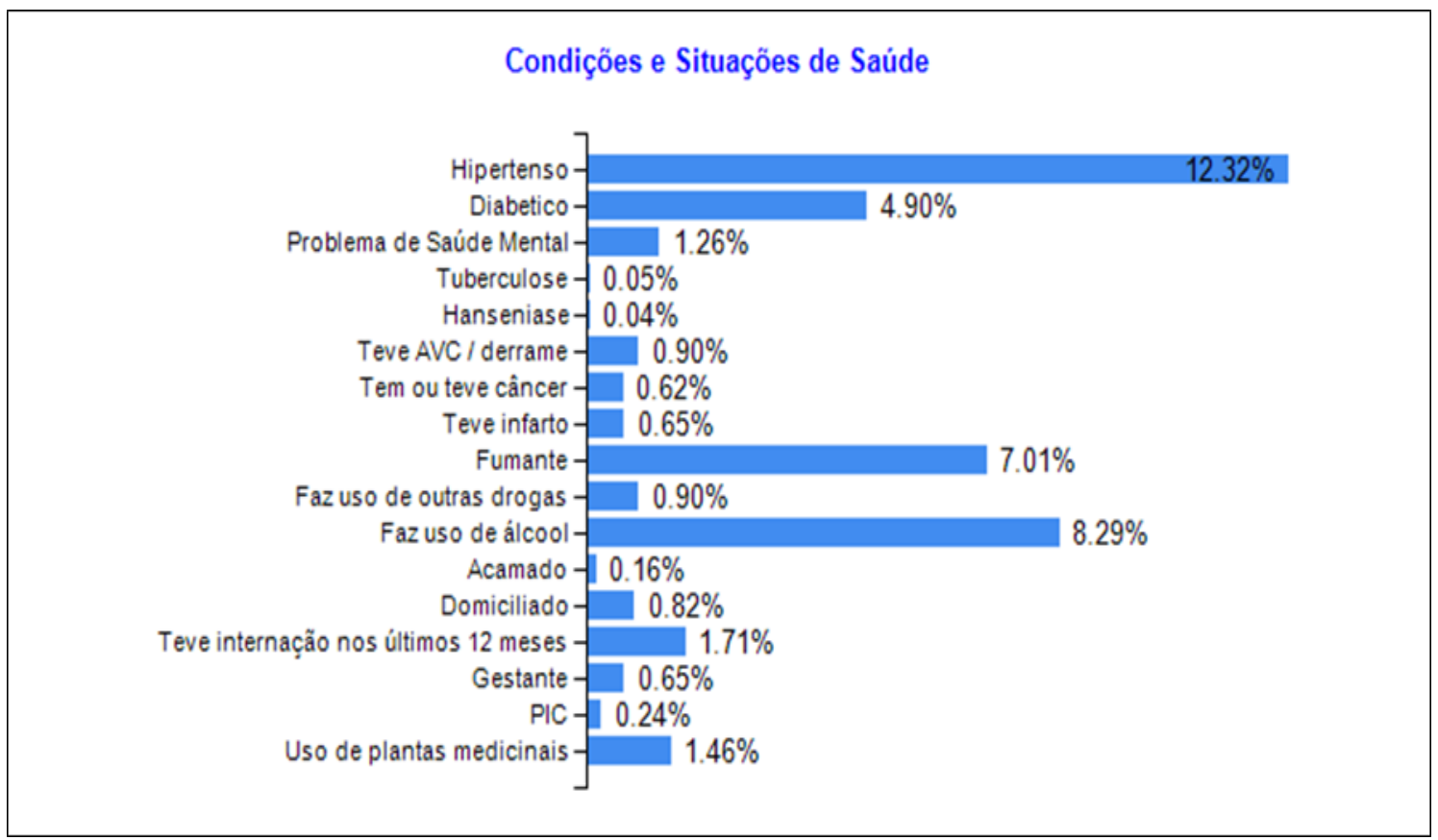

Fonte: Cadastro E-SUS 
Nos gráficos acima, nota-se que a maioria da população é composta por adultos jovens, inseridas num contexto social de grande vulnerabilidade e diferenças sociais entre os territórios.

Diante desse cenário, no nível de atenção da APS, essas unidades trabalham com o modelo da ESF que foi criada pelo MS com o objetivo de consolidar o SUS, que tem como base os princípios de acesso, tais como a equidade, integralidade e universalidade e, também, princípios organizativos como a descentralização, participação da comunidade e regionalização.

A ESF é fundamentada na abordagem coletiva, multi e interprofissional, centrada na família e na comunidade e é composta por equipes de saúde da família que envolvem enfermeiros, médicos, técnicos em enfermagem, odontólogos e ACS.

\subsection{SUJEITOS DA PESQUISA}

Os participantes desta pesquisa foram as(os) profissionais enfermeiras(os) que atuam em unidades de ESF nas áreas descritas anteriormente e as famílias sob os cuidados dessas(es) enfermeiras(os) que aceitassem participar da pesquisa.

Entre possibilidades de selecionar profissionais das USF aleatoriamente ou de acordo com os conhecimentos e experiências no trabalho, optou-se pela seleção aleatória a quem manifestasse interesse na participação. Isso decorreu em função de outro projeto de pesquisa que utilizaria como fonte de dados os mesmos participantes. Como critério adotado, todos os participantes deveriam ser enfermeiros de equipe de ESF de uma das treze (13) UBS sob administração da SBIBAE, mediante a isso, a seleção dos participantes atenderia as duas pesquisas que se utilizariam dos mesmos dados coletados.

Como primeiro contato e meio de motivação para a participação, adotou-se o envio de uma carta-convite por e-mail. Sendo assim, os participantes foram selecionados mediante a aceitação dessa carta que foi enviada aos oitenta e sete (87) enfermeiros que compõem as equipes de ESF das treze (13) UBS administradas pelo PPP da SBIBAE nas áreas de Vila Andrade e Campo Limpo.

Dos 87 enfermeiros convidados, quatorze (14) aceitaram participar da pesquisa. Entretanto, no dia da oficina introdutória, somente sete (7) enfermeiras compareceram. As ausências dos demais participantes foram justificadas pelos gestores das unidades correspondentes alegando "desfalque" na escala do serviço, o que impactaria diretamente no atendimento à população. 
Durante a pesquisa, um dos enfermeiros desistiu de sua participação sob alegação de não dispor de tempo para realizar o preenchimento do instrumento proposto, sendo, portanto, seis o número de enfermeiras que efetivamente participaram do estudo.

Visando a redação final deste estudo e respeitando os preceitos éticos em pesquisa, os participantes e as pesquisadoras receberam nomes de flores para garantia do sigilo.

\subsection{INSTRUMENTO DE COLETA DE DADOS}

A publicação "A família como foco da Atenção Primária à Saúde” traz diferentes ferramentas de abordagem familiar que devem ter por finalidade a representação gráfica da estrutura da família e uma proposta diagnóstica, sendo aplicadas segundo as necessidades apresentadas em cada caso (Chapadeiro, Okano, Araújo, 2011).

Outros autores também enfatizam a importância do uso das ferramentas de abordagem familiar para cumprir um dos atributos da APS que é a orientação familiar. A partir dessas ferramentas que se consegue uma atenção centrada na família e não somente no indivíduo. De um ponto de vista prático, essas famílias devem ser cadastradas, classificadas por vulnerabilidade e participar de encontros clínicos realizados com a utilização das ferramentas de abordagem familiar, possibilitando que o profissional tenha um plano de cuidados voltados para a família, proposta muito próxima àquela indicada pela SAE com abordagem familiar (Alves, Gasparello, 2015; Cubas, Nóbrega, 2015; Mendes, 2012;). A compreensão dessas ferramentas se faz necessária para conhecer as famílias e, sem dúvida, suas especificidades, indicando as que pertencem a grupos sociais de maior vulnerabilidade.

Estudos já citados anteriormente mostraram que uma das limitações para o desenvolvimento da SAE é a falta de impresso específico. Diante dessa realidade, quais seriam as características de um bom instrumento para nortear o atendimento à família na ESF?

Buscando contribuir para o desenvolvimento de uma ferramenta de cuidado à família para a prática da(o) enfermeira(o) da ESF, optamos por utilizar como base um instrumento que foi desenvolvido, em 2017 na disciplina voltada para o ensino da AB para auxiliar na sistematização do cuidado à família ministrada pelo Departamento de Enfermagem em Saúde Coletiva da Escola de Enfermagem da USP.

Por ser originariamente um instrumento com finalidade pedagógica, percebeu-se que seria inviável sua aplicação na prática, pois tratava-se de um instrumento extenso, com um total de nove perguntas fechadas e abertas, que abrangiam dados gerais de composição familiar, 
reprodução social (momento da produção e momento de consumo - inserção no grupo/fração de classe), dinâmica familiar e o próprio plano de cuidados a ser desenvolvido, distribuídas ao longo de seis páginas (Anexo 4).

Diante disso, o instrumento foi adaptado pelas pesquisadoras para um formato exequível na prática profissional da(o) enfermeira(o) da ESF. Para essa readequação, as pesquisadoras optaram por reagrupar, eliminar e adaptar algumas questões, sem perder a essência principal do instrumento original. Ponderou-se que um instrumento excessivamente longo seria pouco aplicável, sabendo de antemão a regulação do tempo aplicado às consultas de enfermagem (CE) e demais atividades, além das "metas" quantitativas que a(o) enfermeira(o) deveria alcançar em número de $\mathrm{CE}$ e em visitas domiciliares (VD).

A ferramenta readequada, denominada de "Instrumento de apoio para elaboração do plano de cuidado à família" (Apêndice 3), foi compactada a uma estrutura semelhante à da SAE:

a) Histórico: composto por oito questões, abertas e fechadas, com a finalidade de captar a composição da família, a reprodução social e a dinâmica familiar.

b) Diagnósticos de Enfermagem levantados pelo profissional, evidenciando pontos de fortalecimento e pontos de desgaste daquela família.

c) Plano de Cuidado e Implementação: após o levantamento dos diagnósticos de enfermagem, o enfermeiro buscaria uma visão mais ampla sobre a família a ser assistida, possibilitando, dessa forma, a construção de um plano de cuidado familiar em conjunto com os seus membros, elegendo suas principais necessidades.

d) Avaliação: o profissional tem a possibilidade de olhar para o plano de cuidado proposto e avaliar se foi efetivo ou não, se precisa de readequação ou se pode iniciar um novo plano de cuidados para outros pontos a serem trabalhados naquela família.

A fim de auxiliar as(os) enfermeiras(os) na aplicação do "Instrumento de apoio para elaboração do plano de cuidado à família", foi anexado outra página para consulta (Apêndice 4), que contém as orientações básicas para a elaboração de um genograma e ecomapa (com bibliografia recomendada para consulta caso tenham alguma dificuldade) e os principais diagnósticos de enfermagem familiar, incluindo NANDA e CIPESC por serem os mais conhecidos e citados pelos profissionais.

Os participantes também deveriam preencher outro instrumento (Apêndice 5) com a caracterização do profissional em nome, idade, tempo de formação, se possui especialização na 
área da ESF, tempo de atuação como enfermeiro de ESF e tempo de atuação na atual equipe de ES, havia também um espaço específico para que eles pudessem colocar suas percepções e sugestões sobre o "Instrumento de apoio para elaboração do plano de cuidado à família".

\subsection{PROCESSO DE COLETA DE DADOS}

\subsubsection{A escolha pelo grupo focal}

Diferentemente do que ocorre na entrevista individual, o Grupo Focal (GF) permite a interação entre pessoas que fazem parte de um mesmo grupo, o que de nosso ponto de vista é favorável, pois propicia um ambiente enriquecedor para a discussão de um determinado tema. Sua formação obedece a critérios previamente determinados pelo pesquisador de acordo com os objetivos da investigação, cabendo ao estudioso a criação de um ambiente favorável à discussão, que permita aos participantes a manifestação de suas percepções e pontos de vista (Minayo, 2000; Patton, 1990).

Os GF definem-se como uma técnica de pesquisa qualitativa, derivada das entrevistas grupais, que coleta informações por meio das interações entre as pessoas (Morgan, 1997). O GF é uma forma de entrevistas com grupos, baseada na comunicação e na interação. Seu principal objetivo é reunir informações detalhadas sobre um tópico específico (sugerido por um pesquisador, coordenador ou moderador do grupo) a partir de um conjunto de participantes selecionados. Ele busca coletar informações que possam proporcionar a compreensão de percepções, crenças e atitudes sobre um tema, produto ou serviço (Zanella, 2013).

Estudos sobre GF descrevem que seus participantes devem apresentar certas características em comum que estão associadas à temática central em estudo. O grupo deve ser, portanto, homogêneo em termos de características que interfiram radicalmente na percepção do assunto em foco. Recomenda-se que os participantes sejam selecionados a partir de um conjunto de indivíduos que convivam com o assunto a ser discutido e que tenham profundo conhecimento dos fatores que afetam os dados mais pertinentes (Trad, 2009).

Portanto, a escolha da técnica do GF como uma das estratégias metodológicas deste estudo resultou da compreensão de que assim se promoveria uma participação ativa dos sujeitos da pesquisa, a partir do processo de interação social, como aspecto essencial para coleta de dados. Entendeu-se que tal estratégia daria aos participantes a oportunidade de ampliar seus pontos de vista e refletir sobre o tema família e sobre a ferramenta proposta, alcançando o exercício de concepções grupais acerca do tema proposto. 
Ademais, considerando a dinâmica dos trabalhos desenvolvidos pelas(os) enfermeiras(os) no cotidiano, não haveria ninguém melhor que esses profissionais num processo reflexivo e dialógico para colaborar na construção de uma ferramenta efetiva para lidar com famílias (Backes et al., 2011; Tanaka, Santana, 2018).

No cômputo geral, obtiveram-se 18 (dezoito) instrumentos aplicados a diferentes famílias, em um total de três por participante. Ao examinar o material preenchido, constatouse que todos os participantes aplicaram o instrumento em famílias consideradas por eles como casos complexos no desenvolvimento de cuidados.

\subsubsection{Etapas da pesquisa}

O estudo foi desenvolvido em três etapas:

- Etapa 1 - Oficina introdutória;

- Etapa 2 - Aplicação dos "Instrumentos de apoio para a elaboração do plano de cuidado à família" e registro das percepções dos profissionais sobre a utilização do instrumento visando ao cuidado de âmbito familiar;

- Etapa 3 - GF para apresentação das percepções sobre a utilização do "Instrumento de apoio para a elaboração do plano de cuidado à família" intercalando o debate sobre as mesmas com acolhimento de sugestões para a sua melhoria. Os GF foram desenvolvidos sob a coordenação das pesquisadoras assumindo os papéis de moderadoras e coadjuvantes para garantir o processo grupal.

A realização da oficina introdutória teve duração de duas horas, com os seguintes objetivos:

$\checkmark$ Acolher os profissionais e exposição do projeto envolvendo as fases da pesquisa.

$\checkmark$ Apresentar do "Instrumento de apoio para a elaboração do plano de cuidado à família" para os profissionais (Apêndice 3);

$\checkmark$ Entregar e explicar o material de apoio (Apêndice 4);

$\checkmark$ Identificar do repertório das(os) enfermeiras(os) sobre as necessidades de saúde, família e SAE para alinhamento do referencial teórico. 
Quadro 1 - Estruturação da oficina introdutória para os profissionais participantes na pesquisa. São Paulo - SP, 2019.

\begin{tabular}{|l|l|}
\hline \multicolumn{2}{|c|}{ Estruturação da oficina introdutória } \\
\hline 10 min & Recepção e apresentação dos participantes \\
\hline 20 min & Apresentação e explicação sobre a pesquisa \\
\hline 20 min & $\begin{array}{l}\text { Apresentação do "Instrumento de apoio para elaboração do plano de cuidado à } \\
\text { família" e entrega do material }\end{array}$ \\
\hline 60 min & Diálogo sobre necessidades de saúde, família e SAE \\
\hline 10 min & Encerramento com a definição de data para realização do GF \\
\hline
\end{tabular}

Após a oficina introdutória, os profissionais retornaram para suas unidades munidos do "Instrumento de apoio para elaboração do plano de cuidado à família" (Apêndice 3) para serem aplicados a até três famílias. Foi cogitado esse quantitativo para utilização do material com o objetivo de que os profissionais maximizassem suas experiências com famílias de estruturas distintas, além de vivenciar diferentes atividades de cuidados, tais como consulta de enfermagem dentro da unidade, visita domiciliária, grupo e outras. Ressalta-se que no instrumento havia um campo para o registro das percepções e sugestões acerca da composição dos itens (Apêndice 5). Essas perspectivas metodológicas tiveram como objetivos a diversificação de possibilidades para sua utilização e aplicabilidade dentro da rotina da(o) enfermeira(o) da ESF.

A escolha das famílias se deu por uma avaliação prévia e aleatória da(o) enfermeira(o) das equipes de ESF.

Após a utilização do instrumento e a análise do mesmo pelas(os) enfermeiras(os) participantes da pesquisa, foi realizado um GF para propiciar um espaço amplo de discussão a respeito da experiência vivenciada.

Embora fossem esperadas seis enfermeiras(os) para a realização do GF, apenas duas compareceram. Quatro enfermeiras(os) se ausentaram por divergências do horário em relação à escala de trabalho. Por este motivo, houve a necessidade da realização de um segundo GF para contemplar os outros quatro participantes da pesquisa. 
Cada um dos dois Grupos Focais realizados teve duração média de uma hora e trinta minutos, esses grupos foram gravados em áudio e posteriormente transcritos, as duas pesquisadoras se dividiram nos papéis de moderadora e de observadora para a condução dos GF, que tiveram como objetivo:

$\checkmark$ Recolher os instrumentos aplicados pelas(os) enfermeiras(os) nas famílias do território.

$\checkmark$ Debater junto às enfermeiras sobre suas percepções acerca do instrumento, relacionado a sua estruturação, limites e potencialidades.

\subsection{ANÁLISE DE DADOS}

Buscou-se organizar os dados de modo que eles revelassem com objetividade como os participantes percebiam e se relacionavam com o objeto proposto para o estudo (Minayo, 2000). Para tanto, adotou-se a análise de conteúdo para apreender as percepções expressas, pistas e insights sobre a ferramenta objetivando o cuidado familiar. Chamou a atenção, como aspecto limitante, a questão do tempo regulado, advindo do modelo de gestão.

Os dados dos GF, tanto do primeiro quanto do segundo, foram transcritos na íntegra pela pesquisadora. Os materiais transcritos foram submetidos às leituras cuidadosas por dois pesquisadores a fim de apreender os conteúdos e unidades de significado. Após esse investimento de tempo nas leituras, procedeu-se ao processo de categorização desses conteúdos visando a coerência com os objetivos.

As categorias analíticas foram de:

A. Processo de trabalho da(o) enfermeira(o)

A.1 Cuidar da família como processo e objeto

A.2 Instrumento de cuidado à família

B. Contradições no sistema de organização do trabalho

A análise foi centrada no aspecto estrutural, na adequação e na abrangência dos itens para o cuidado processual na realidade prática. 
6 RESULTADOS E DISCUSSÃO 


\section{RESULTADOS E DISCUSSÃO}

Os resultados envolvem parte da oficina introdutória e os dados coletados em GF.

Conforme a metodologia indicada, na primeira fase, apreenderam-se algumas características dos participantes sumarizadas no Quadro 2.

Quadro 2 - Perfil dos profissionais participantes em idade, tempo de formação, curso de especialização/residência em saúde da família, tempo de atuação como enfermeira(o) na ESF e tempo de trabalho na equipe atual. São Paulo - SP, 2019.

\begin{tabular}{|c|c|c|c|c|}
\hline $\begin{array}{c}\text { Idade } \\
\text { (anos) }\end{array}$ & $\begin{array}{c}\text { Tempo de } \\
\text { formação } \\
\text { (anos) }\end{array}$ & $\begin{array}{c}\text { Curso de } \\
\text { especialização ou } \\
\text { Residência em Saúde } \\
\text { da Família }\end{array}$ & $\begin{array}{c}\text { Tempo de atuação } \\
\text { como enfermeira(o) } \\
\text { de ESF } \\
\text { (anos) }\end{array}$ & $\begin{array}{c}\text { Tempo de trabalho } \\
\text { atual na equipe } \\
\text { (meses) }\end{array}$ \\
\hline 38 & 13 & Sim & 13 & 36 \\
\hline 30 & 06 & Sim & 05 & 03 \\
\hline 28 & 04 & Sim & 15 & 48 \\
\hline 40 & 16 & Sim & 15 & 36 \\
\hline 38 & 15 & Sim & 06 & 03 \\
\hline 39 & 15 & Não & & 48 \\
\hline
\end{tabular}

Fonte: própria pesquisadora

A maioria 83,33\% dos profissionais referiu capacitação específica em saúde da família. Quanto ao tempo de formação, apresentou-se uma a média de 11,5 anos. Observa-se que os participantes já atuavam em unidades de Saúde da Família em média de 9,5 anos, e, na equipe atual, uma média de 30 meses. Frente a esses perfis dos participantes, chama a atenção o fato de os resultados em GF apresentarem certo desconhecimento sobre ferramentas comumente utilizadas para com o cuidado a famílias, aspecto que está abordado mais adiante.

No cômputo geral, obtiveram-se 18 (dezoito) instrumentos aplicados a diferentes famílias, em um total de três por participante. Ao examinar o material preenchido, constatou-se que todos os participantes aplicaram o instrumento em famílias consideradas por eles como casos complexos no desenvolvimento de cuidados. 
Iniciaremos a apresentação de resultados mostrando um panorama dos aspectos mais mencionados pelos participantes, classificados em duas grandes categorias, quais sejam: a) processo de trabalho do enfermeiro e b) contradições no sistema de organização do trabalho. É importante esclarecer que a primeira foi subdividida em duas subcategorias: "cuidar da família como processo e objeto" e "instrumento de cuidado à família".

Do total de 45 (quarenta e cinco) itens selecionados como falas representativas no que tange à prática do cuidado às famílias, seguindo a ordem dos mais ressaltados, tem-se: 48,8\% mencionam o reconhecimento e a necessidade de um instrumento mediador para planejar o cuidado às famílias; $28,8 \%$ se referem a cuidar da família como processo e objeto; e 22,2 \% falam sobre as contradições no sistema de organização de trabalho.

É importante salientar que, nos dois encontros de GF, as pesquisadoras procuraram conduzir a interação entre os participantes de forma a sustentar um processo construtivo no que se refere ao aprimoramento de um instrumento que ampliasse o olhar sobre o cuidado às famílias ao mesmo tempo que pudesse captar, para outro núcleo de pesquisa, as necessidades de saúde.

No primeiro encontro de GF, foi promovido um resgate do que foi discutido no encontro inicial do projeto de pesquisa, quando as pesquisadoras avaliaram pertinente retomar o conceito de família como importante base não somente para o projeto, mas também para a prática mesma das(os) enfermeiras(os). A este estímulo que partiu da Moderadora Gérbera e da Observadora Amarílis, os participantes manifestaram-se espontaneamente procedendo à primeira fala, elencada abaixo na subcategoria do processo de trabalho do enfermeiro. A Observadora Amarílis teve a oportunidade de enriquecer as interações originadas no grupo reportando-se à diversidade do entendimento conceitual sobre família na atualidade, em virtude das transformações que ocorreram ao longo da história, já descritas no apoio teórico (Brasil, 1988; 1998b; Bruschini, 1989; Bruschini, Ridenti, 1994; Egry, Fonseca, 2000; Engels, 2017; Faco, Melchiori, 2009; Ferreira, 2010; IBGE, s.d.; Itaboraí, 2015; Minuchin 1985; Silva, Silva, Bousso, 2011; Wernet, Angelo, 2003).

O objeto de trabalho, destacado como categoria analítica junto ao cuidar da família, emergiu mediante o estímulo da Moderadora Gérbera ao convidar o grupo a pensar na diferença de cuidado individual para o familiar.

a) Processo de trabalho da(o) enfermeira(o)

a.1) Cuidar da família como processo e objeto

Chamou a atenção as falas das participantes relacionadas ao conceito de família, o que é fundamental para formular ações, a fala abaixo surgiu do questionamento de uma das 
participantes sobre ter aplicado o instrumento de forma errada visto que a família selecionada por ela era constituída apenas de uma pessoa, em sua concepção, não se tratava de uma família e sem de uma pessoa:

\section{(...) é, acho que fiz errado no conceito do que é família (...)}

Camélia

O discurso da Camélia e da Orquídea indica o perceber da dimensão familiar, ou seja, a mudança de objeto de trabalho, do foco individual para a família:

(...) a gente não tem o hábito de perguntar da família(...) eu pude organizar o cuidado com aquela família (...) a gente não costuma perguntar: como está o relacionamento com o seu esposo. Como estão com os filhos? (...)

Camélia

(...) Éeeee,..., isso, você vai falar daquela pessoa (...) exemplo numa delas que eu fui, foi abandono de tratamento de tuberculose, estava focado no abandono do tratamento dela e aí depois quando eu fui colocar tudo no papel (...) fui percebendo o contexto da família (...)

Orquídea

$\mathrm{Na}$ continuidade do processo interativo e dialógico, logo após os estímulos da Moderadora Gérbera e da Observadora Amarílis, que indagaram sobre o que os participantes percebiam de positivo ao aplicar o instrumento, houve uma receptividade ao questionamento e o grupo articulou as premissas da $\mathrm{AB}$ que defende o cuidado longitudinal como uma das características da atenção primária, com o instrumento proposto.

(...) eu acho que o instrumento tem muito a ver com a continuidade do cuidado (...) ver o que foi feito (...) se conseguiu os resultados, palpar mesmo(...)

Orquídea

A fala seguinte, contrasta com a ideia do cuidado longitudinal ao relatar que o prontuário eletrônico secundariza os registros em papel. As famílias residem e vivem num determinado território e, nesse sentido, o registro em papel também guarda a visão do processo saúde-doença 
cronologicamente. Na fala abaixo, a participante não vê necessidade em consultar o histórico familiar que consta no prontuário físico.

(...) antes a gente trabalhava com prontuário de papel, hoje eles ficam no arquivo e, raramente eu desço no arquivo. Por que o que é que tem lá que eu queira ver? (...)

Camélia

Ainda em relação ao processo de cuidar, encontramos:

(...) a consulta de pré-natal é de 20 minutos, então, deu para aplicar o instrumento

(...) realizar o diagnóstico de enfermagem é o que demanda mais tempo (...)

Camélia

Nessa categoria, selecionaram-se essas falas representativas que ressaltam a dimensão do cuidar com o objeto família.

a.2) Instrumento de cuidado à família

Como foi exposto anteriormente, esta categoria reuniu maior número de depoimentos que salientaram a importância da existência de um instrumento bem como sua necessidade para organização de cuidado familiar.

(...) de aplicação fácil (...)colabora para analisar um a um e assisti-los melhor (...) dependendo do diagnóstico familiar você consegue identificar porque aquele determinado paciente tem uma determinada situação (...)

Orquídea

(...) eu achei que contribuiu na organização do cuidado com a família (...) eu acho que a gente teria que fazer realmente, é que na grande maioria a gente não consegue fazer (...) pra questão da organização do cuidado contribuiu muito (...)

Bromélia

A fala da Azaléia (abaixo) expressa a expectativa do profissional em relação ao instrumento como algo transformador para isso. 
(...) eu escolhi essa família, porque a família toda era problema (...) eu não conseguia ter a dimensão do problema, palpar o problema, isto (instrumento) me ajudou muito (...)

Azaléia

A fala seguinte reflete o dado entendimento sobre o instrumento dando a ideia de que a aplicação dever ser rápida.

(...) o instrumento, se for em formato de checklist ficaria mais fácil, até mesmo a parte dos diagnósticos (...)

Girassol

b) Contradições do sistema de trabalho

A contradição consiste numa incompatibilidade lógica entre uma das proposições, ou seja, quando são opostas uma à outra. Isso corre quando as proposições.

(...) não é muito fácil né, por conta do tempo que tem (...) eu fiz na VD porque na unidade fica muito corrido (...)

Girassol

(...) Onde colocaria esse instrumento da família? Porque eu não tenho registro familiar, tenho registros individuais (...)

Camélia

(...) família de maior dificuldade, que a gente sabe o prontuário de cor (...) separado em uma planilha discutido no NASF (...) daí, não tem no prontuário visivelmente na hora que eu atendo a pessoa, mas tem no prontuário físico que a gente arquiva as coisas (...)o instrumento não fica na minha mão, até eu ir buscar, na rotina do dia a dia não fica viável

Peônia

(...) demora no preenchimento (...) só fiz na VD (...)

Bromélia

(...) eu tive um pouco de dificuldade na questão de fazer o genograma, não é uma coisa que a gente faz, a gente aprende, mas não faz no dia a dia, mas não faz no dia a dia, mas eu achei 
que ele clarificou muito o cuidado com a família (..) eu pude organizar o cuidado com aquela família (..) em reunião de equipe eu pude ver onde estava errando com esta família (..)

Azaléia

Quadro 3 - Quadro de síntese de evidência das potencialidades e limites do Instrumento de Apoio para elaboração do Plano de Cuidado à Família. São Paulo - SP, 2019.

\begin{tabular}{|c|c|}
\hline Potencialidades & Limites \\
\hline Fácil entendimento & Tempo x Demanda \\
\hline Fortalece o vínculo com a família & Atendimento é individual \\
\hline Permite um olhar ampliado & Não é acessível a equipe "multi” \\
\hline Identifica a mudança de objeto de cuidado & Registro é individual \\
\hline
\end{tabular}

Fonte: própria pesquisadora

Em obra publicada por pesquisadoras da enfermagem em saúde coletiva (Alves, Gasparello, 2015; Cubas, Nóbrega, 2015), organizou-se um conjunto de terminologias voltadas para os cuidados na atenção primária. Primeiramente, tal referência foi fundamental por visualizar a identidade na linguagem de acordo com o objeto de trabalho em enfermagem em saúde coletiva em que se envolve indivíduo, família e comunidade. Em segundo lugar, por perceber a importância do uso da linguagem específica como um instrumento lógico e analítico do pensamento de cuidar em enfermagem em saúde coletiva (Vygotsky, 1998). Em terceiro lugar, o conjunto da leitura tanto da obra relacionada ao modelo Calgary (Wright, Leahey, 2012) como das obras de Enfermagem (Alves, Gasparello, 2015; COFEN, 2009; COREN-SP, 2015; Cubas, Nóbrega, 2015) balizou para a conformação final do instrumento visando cuidados à família. Constataram-se semelhanças estruturais no que diz respeito a núcleo de dados estáticos como de núcleos de informações relacionais e subjetivas para compreender as forças e fragilidades de uma dada família.

A forma original do instrumento pedagógico abrangia, de maneira geral, todos esses aspectos. No entanto, o resultado era um documento muito extenso diante de algumas premissas básicas no processo de reformulação: utilidade e exequibilidade na realidade prática.

Ao analisar os dados classificados conforme os objetivos estabelecidos, nem todos os itens foram tomados pelas participantes como foco de discussão no GF. Desta forma, a proposta final buscou contemplar tanto a riqueza dos itens constantes na literatura como as sugestões e críticas apontadas a partir das vivências e experiências dos profissionais participantes.

É importante salientar que no contexto de trabalho real dos profissionais, de fato, reconhece-se um excesso de demanda assistencial e administrativa que acabou coibindo uma 
maior participação dos profissionais no processo de pesquisa. Isto emergiu nos momentos interativos do GF nos quais constantemente se fez referência à gestão do tempo de aplicação do instrumento e à necessidade de otimizá-lo em cuidados pela regulação estabelecida.

A discussão permeará os dados sistematizados por dois grandes núcleos temáticos: processo de trabalho da(o) enfermeira(o) e contradições do sistema de organização do trabalho. A primeira categoria analítica foi subdividida em dois subtemas: a) cuidar da família como processo e objeto e b) instrumento de cuidado à família. Diante disto, organizou-se a discussão valorizando a voz dos profissionais apoiada na literatura visando à construção de um instrumento de apoio de cuidado às famílias.

Precisamente, o advento do SUS e da AB constituíram-se no contexto público em um marco de ampliação do cuidado individual para a dimensão familiar. Assim, a Saúde da Família apresentou-se como um desafio para a reorientação do modelo assistencial e como uma forma de renovação deste ao prever o cuidado por meio de um trabalho multiprofissional. (Brasil, 2012; 2017).

Uma das grandes inovações no campo da produção do cuidado é a tecnologia em saúde (Merhy, Onocko, 2006). São ferramentas intersubjetivas complexas, originárias do campo de conhecimento da Filosofia e da Psicologia disseminadas como tecnologias leves, referentes a relações de produção de vínculo, acolhimento e escuta gestão dos processos de trabalho (Merhy, Onocko, 2006). Tecnologias relacionais como instrumento para cuidado na ESF (Abreu, Amendola, Trovo, 2017).

A busca por uma ferramenta de cuidado na enfermagem é histórica, tendo, particularmente, o corpo do indivíduo doente como objeto de trabalho. A noção de coletivo na área de enfermagem é ainda recente diante da transformação do mundo sob o regime capitalista e traduz o desejo de profissionalização e qualificação dos cuidados aos pacientes e usuários. Embora o esteio teórico tenha se evoluído pelo enfoque individual, hoje nos alicerça para desenvolver cuidado às famílias. O processo de trabalho da(o) enfermeira(o) faz parte do conjunto de atividades promovidas para proteção mais abrangente, quando emerge a figura da família em oposição ao indivíduo (Almeida, Rocha, 1997).

É nítida a percepção dos participantes que cuidar de uma família é um processo distinto daquele que se emprega para cuidar de um indivíduo, ou seja, os participantes apreenderam à mudança de objeto de cuidado. Essa percepção é fundamental uma vez que ao assumir um outro objeto ou finalidade do trabalho, mudam-se o mediador, o instrumento, o conhecimento e as habilidades. 
O objeto é a principal motivação do trabalho e, neste estudo, toma-se a família como objeto na visão de processo saúde-doença. A família é identificável e socialmente aceita como célula. Os estudiosos advertem que a família não é uma entidade fixa, mas sim um conceito que encerra as dimensões histórica, cultural e econômica transformado no espaço de tempo. Por isso, é importante reconhecer a capacidade transformativa dos membros e da temporalidade (Alves, Gasparello, 2015; Cubas, Nóbrega, 2015; Wright, Leahey, 2012;).

No presente estudo, a apropriação do conceito sobre o objeto família surgiu naturalmente no início do GF e acredita-se ser ele um norteador do trabalho porque é um elemento mediador e determinante do pensar e agir dos profissionais (Virkkunen, Newnham, 2015). Estudo realizado no contexto de Saúde da Família converge ao afirmar a importância do conceito de família para sustentar a abordagem familiar (Silva, Silva, Bousso, 2011).

No que se refere ao aspecto longitudinal do cuidado em Saúde da família, na perspectiva do processo saúde-doença, a criação do sentido de continuidade do cuidado se dará a partir das interações e do desenvolvimento das capacidades em contínuos processos, afastando-se dos modelos pré-concebidos (Alves, Gasparello, 2015; Brasil, 2012; Cubas, Nóbrega, 2015). No comentário da Camélia, evidenciou-se que a separação física da documentação da assistência em prontuário eletrônico e os registros em papel dificulta a interligação das partes, prejudicando a apreensão da totalidade do processo de cuidado em curso, cuja historicidade é vital para compreender os estágios e os processos da vida de uma família.

A partir dessas breves considerações, é possível afirmar que o objeto família depende da qualidade das forças instituintes dos profissionais de saúde conjugadas com as dos membros familiares direcionadas para o objetivo desejado (Vigotskii, Luria, Leontiev, 2010). Em outras palavras, a família é entendida como o objeto de ação do profissional, mas sem que com isso deixe de ser também um agente que, em ato, coloca seus conhecimentos e suas representações para o trabalho em saúde (Zoboli, Fracolli, Chiesa, 2013). Como exposto no corpo teórico, dependendo da finalidade proposta para o objeto, mudam-se os componentes e a ferramenta de trabalho, exigindo distintas habilidades.

Quanto ao instrumento, para avançarmos no raciocínio apresentado no parágrafo anterior, vale retomar algumas propriedades nele contidas. No que se refere à estrutura, tem-se: identificação e composição dos membros com respectivas idades, escolaridades, relação com responsáveis, trabalho, vínculo, condições de moradia e local de nascimento, elementos semelhante aos da Ficha A. Ademais, o instrumento contempla o ciclo de vida familiar, genograma e ecomapa que traduzem, em parte, as relações internas e externa dos membros no contexto ambiental. Associam-se, também, elementos constituintes da síntese da capacidade 
familiar, como fortalecimento e desgastes. Já os itens finais, constituídos por diagnósticos, plano de intervenção familiar de enfermagem e acompanhamento e evolução familiar, possuem maior complexidade por implicarem no processo de criação do caminho de cuidado. Diante desta abrangência, a expectativa manifestada pelos participantes estava, provavelmente, articulada com a ideia de tecnologia pela ótica de amplitude informacional, tornando o processo de cuidar mais palpável.

Os itens acima descritos ganham importância à medida que os profissionais desenvolvam a capacidade de articulação entre as partes constitutivas do todo - a estrutural, as relações internas e externas entre membros e a identificação dos aspectos de fortalecimento e de desgastes, uma vez que a pesquisadora adotou uma concepção construtivista das ações de intervenção e do objeto - na situação de produção (Alves, Gasparello, 2015; Chapadeiro, Araújo, 2011; Okano, Cubas, Nóbrega, 2015; Wright, Leahey, 2012).

Observou-se que as participantes entrevistaram famílias consideradas por elas “complexas”, como retratada na fala da Azaléia: (...) a família toda era problema (...). Essa percepção indica que, no momento da aplicação do instrumento, pode ter sido gerada uma grande expectativa a ponto de selecionarem casos complexos, aparentemente, sobre o imaginário na potência do instrumento revestida de tecnologia.

A expressão "tecnologias" vem sendo utilizada no campo da saúde para designar a sistematização dos diversos modos de produzir saúde. Neste sentido, a tecnologia deve ser compreendida como um conjunto de ferramentas, entre elas as ações de trabalho, que põe em movimento uma ação transformadora da natureza (Merhy, Onocko, 2006).

A proposta que se apresenta, especialmente na segunda parte do instrumento, compõese de aspectos relacionais em família e exige uma compreensão diferenciada enquanto tecnologia no processo produtivo. É denominada como uma tecnologia relacional e podemos afirmar que de suficiente domínio e reconhecimento dos profissionais de saúde, já estando incorporada na gestão de cuidados: acolhimento, espaço de encontro, vínculo, escuta e corresponsabilização (Abreu, Amendola, Trovo, 2017; Martins, Albuquerque, 2007; Merhy, Onocko, 2006).

Em saúde, a maioria das ações laborais são intercaladas por interações humanas que, denominadas por estudiosos da área como trabalho relacional (Edwards, 2017). Tratam-se de produções originalmente do setor de serviços conhecidas como de natureza imaterial e subjetiva, de forma que o processo de produzir e consumir ocorre simultaneamente entre os atores. Esse processo em saúde é conhecido como produzir no ato e qualificado como trabalho vivo no ato pela participação do usuário no processo de tomada de decisão. Por essas razões, 
além do grau de interação já mencionado, em serviço de saúde sempre importa a intensidade com que os profissionais se envolvem na resolução ou no encaminhamento de uma dada situação de um usuário ou uma família. Essas produções, embora de caráter imaterial e subjetiva, são potentes para construir o curso das ações (Merhy, Onocko, 2006). Em busca de ferramentas analisadoras das tecnologias em saúde: a informação e o dia a dia de um serviço, interrogando e gerindo trabalho em saúde (Merhy, Onocko, 2006; Silva, Silva, Bousso, 2011).

Voltando a examinar o instrumento, é importante ressaltar que itens como genograma, ecomapa, e relacionamento com a comunidade são elementos que exigem, além do conhecimento prévio sobre essas ferramentas, uma postura ética ao se considerar esse conjunto de informações como mediador de cuidados no compasso das famílias. Considerando a análise do tema relacionado, entende-se que a aplicação da tecnologia leve é genuinamente de construção conjunta como modo de produção (Merhy, Onocko, 2006).

Para lidar com essa complexidade do objeto família, ao proceder a presente investigação, tanto no momento de aplicação do instrumento como no GF, ficou claro que as participantes tiveram dificuldade de apropriação do genograma e do ecomapa como uma das ferramentas integrantes no instrumento, mesmo acompanhados de material de apoio com ilustrações gráficas, embora tenha sido oferecida uma bibliografia para consulta associada à explicação das pesquisadoras na sessão de Oficina introdutória. Apesar disso, não se observou envolvimento das participantes o que reduziu a oportunidade de sua contribuição na pesquisa. Evidenciou-se, assim, a necessidade de instrumentalização técnica dos profissionais relacionada ao conhecimento da dimensão família. O conjunto de saberes, habilidades, empenho e envolvimento é parte fundamental de uma tecnologia leve (Abreu, Amendola, Trovo, 2017; Merhy, Onocko, 2006).

É pertinente apontar a necessidade de capacitação dos profissionais sobre as ferramentas de avaliação familiar já existentes e da evolução dos conceitos de família existentes como propositivo do SUS, como também sobre a sistematização da assistência de enfermagem sem, dissociar trabalho e formação na perspectiva de manter os profissionais atualizados e motivados.

Dessa forma, o instrumento em si, embora proposto com intenções muito positivas, não pode impactar de maneira significativa a qualificação do cuidado, pois a aplicação, sistematização e interpretação de suas informações requerem conhecimento e habilidades necessárias na mediação do cuidado familiar.

A instituição na qual os profissionais participantes estão inseridos tem como política uma meta anual de tempo destinado à formação individual visando qualificação do cuidado. 
Coincidentemente, sabe-se que a instituição empregadora promoveu, no ano anterior ao desenvolvimento deste estudo, uma capacitação, contemplando os profissionais de formação universitária, dentre eles, as(os) enfermeiras(os), na qual foi abordado um tema afim: as ferramentas de abordagem familiar. Diante desse investimento realizado ao longo de um ano, esperava-se um retorno mais assertivo no desempenho das funções.

Conceitualmente, a contradição advém da tensão de forças opostas do microssistema. (Engeström, 2016). Essa categoria analítica difere das demais, pois extrapola a governabilidade dos profissionais ao buscar resolução de problemas.

Surgiu fortemente no GF a questão de tempo como barreira para aplicação do instrumento objetivando cuidado à família, pois, no dia a dia dos profissionais, a lógica dominante está para atenção individual regulada em tempo. Paralelamente, o prontuário eletrônico do sistema de informação das Unidades Básicas é de registro individual, reforçando a contradição em relação aos pressupostos do modelo Saúde da Família a partir do qual se entende, que a família é a menor unidade de trabalho (São Paulo, 2015).

No que se refere à regulação do tempo, entende-se que a questão está relacionada ao paradigma tradicional de produção de bens do modelo fordista, centrado no rendimento individual do trabalho vinculado à ideia de produtividade. Acredita-se que esteja também vinculada com o modelo de gestão guiada pelos compromissos vigentes em convênio, fazendo jus à mensuração quantitativa de resultados negociados em metas por parte das instâncias pública e privada. Dada essa realidade, a questão regulatória no processo operacional de serviços pode ser compreendida como uma das consequências dos Termos do Convênio e do modelo de gestão em vigor (São Paulo, 2014).

Diante dessas características de controle, vale ressaltar o conceito de serviço segundo os estudiosos. A ideia central é que o serviço é definido como a aplicação de competências em benefício de outra parte, no nosso caso, os(as) usuários(as) de serviços de saúde (Fitzsimmons, Fitzsimmons, 2014). Observa-se, com isto, certa dissonância na quantificação de metas como resultados, no lugar de mensurar o impacto nos usuários(as). Alia-se a isso também o conceito de cuidar exposto no apoio teórico assim como a natureza processual de cuidado mediado pelas interações humanas devendo haver flexibilidade de tempo de acordo com a necessidade (Zoboli, Fracolli, Chiesa, 2013).

Como mencionado anteriormente, uma pesquisa realizada em Portugal teve uma proposta semelhante ao criar um instrumento de cuidado à família destinado aos profissionais de enfermagem. É interessante observar que a pesquisadora se defrontou com o problema de se ter um sistema de informação estruturado até então para documentação individual. No 
desenvolvimento desse estudo, conseguiu-se reverter a situação adequando o Sistema de informação de tal forma que imputassem informações de unidade familiar. Consequentemente, h ampliar o escopo do trabalho da enfermagem (Figueiredo, 2009).

A contradição entre os pressupostos de Saúde da Família e a organização do sistema de informação é identificada ainda pela fala das participantes que indicam a existência da dissociação entre o objeto de trabalho das equipes e a gestão dos recursos-meio. Observa-se, dessa forma, o distanciamento da unidade de objetivos conjuntos como processo de construção.

Nesse sentido, a fala da Camélia ilustra bem essa realidade que confronta a lógica da gestão instituída:

\section{(...) onde colocaria esse instrumento da família? Porque não tenho registros de família, tenho registros individuais (...)}

Ao refletir sobre a trajetória da Reforma Sanitária, que defendeu a mudança de modelo e do modo de produção, e considerando que a Saúde da Família foi implementada estrategicamente para modificar a lógica do cuidado individual para a visão coletiva, esta realidade indica um retrocesso político e organizacional, posto que o modelo de gestão enfatiza o atendimento individual não se mostrando, portanto, articulado aos pressupostos do modelo de Saúde da Família.

Assim, buscou-se adequar a linguagem para favorecer a uniformidade da compreensão e interpretação do conteúdo abordado. Especialmente o manejo da família envolve aspectos éticos na construção de caminhos de cuidados, sempre que possível, no compasso da família envolvida.

1) As informações estruturais relacionada à composição familiar e atividades econômicas e escolaridades respectivas dos membros foram mantidas com exceção do item - relação com o responsável - com o qual apontava um membro, chefe de família - na perspectiva de quem propicia à família meios financeiros para atendimento de necessidades. Considerou-se que na atualidade essa relação modificou relativizando a relação patriarcal ou à hegemonia masculina. No entanto, a natureza do trabalho e o tipo de vínculo foram mantidas;

2) O ciclo de estágio da família no qual busca conhecer o processo de desenvolvimento da família que passam por diferentes inserções sociais condicionado às faixas etárias de membros de recém-nascidos à infância, adolescência, adultos, envelhecimentos e demais desdobramentos foram acrescidas; 
3) O genograma e ecomapa fornecem o estado de funcionalidade da família revelando o estado de arte das relações entre membros no momento pesquisado. Admite-se que as relações são dinâmicas e podem sofrer modificações com ou sem intervenção externa e interna;

4) Os itens de relação de ajuda e interdependência da família na comunidade foram mantidos uma vez que essas interações são necessárias e implicam no processo de convivência. Esses aspectos foram reduzidos a menores itens evitando repetição.

5) A síntese de fortalecimento e desgaste são dados de um balanço do conjunto da situação de uma família que dão visibilidade às alternativas de cuidados como de investimentos de maior intensidade para superar uma dada situação. Mantido desde o início;

6) O Diagnóstico de enfermagem familiar indica o estado de saúde de uma família conforme a taxonomia adotada. Sendo ele base para as ações de intervenção em enfermagem. Mantido desde o início desta elaboração;

7) O Plano de intervenção refere-se às ações concretas destinadas à uma família;

8) A fase de evolução e acompanhamento referem-se aos resultados parciais das ações planejadas.

A proposição deste instrumento será um avanço na Estratégia Saúde da Família na perspectiva de resgatar a unidade família como foco de atenção das equipes dos territórios. 


\section{CONSIDERAÇÕES FINAIS}

Como metodologia de pesquisa, o caráter ativo das participantes e das pesquisadoras no presente estudo oportunizou processos reflexivos para lidar com a família na sua complexidade. O estudo se constituiu de um processo colaborativo de ambas as partes, entre as pesquisadoras e os participantes, compartilhando o processo de construção de uma ferramenta de cuidado às famílias.

Reafirma-se que foram fundamentais o caminho de relações dialógicas para coleta de dados qualitativos com os profissionais-atores da prática ao legitimar seus saberes e habilidades, sendo eles que de fato lidam com o contexto e a diversidade das necessidades e o modo de viver das famílias. Entretanto, reconheceram-se limitações na compreensão de alguns aspectos vitais do instrumento como genograma e ecomapa, cujas abordagens exigem capacidade de operar os conceitos como família e o cuidar de famílias, de forma compartilhada e processual com os usuários.

De maneira geral, o instrumento contribuiu para o processo construtivo do cuidado familiar pois permitiu que se partisse de algo estruturado mesmo para finalidade pedagógica, buscando alinhar a coerência entre os fundamentos teóricos e a adequação de terminologias específicas no campo de enfermagem em saúde coletiva.

O trabalho é inerente à natureza humana dotada de energia física e mental com as quais imprimem a capacidade valorativa e criativa em relação ao objeto que se deseja transformar. Para a transformação do objeto, o homem instintivamente opta por uma ferramenta mediadora, centrando-se no resultado final. Esse fundamento marxiano sobre o trabalho humano esteve presente no processo de pesquisa quando foi evidenciada a necessidade de um instrumento para processar o cuidado às famílias, o que pode ser interpretado como uma das potencialidades no aprimoramento do trabalho.

O instrumento ora apresentado foi projetado dialogando com as atribuições da(o) enfermeira(o), porém é possível repensá-lo para que se torne uma ferramenta comum entre os membros da equipe multidisciplinar como pressupõe o trabalho em Saúde da Família.

No que tange ao aprimoramento metodológico, reconhece-se a possibilidade de ampliar a participação de profissionais buscando a homogeneidade em conhecimentos e habilidades para maior unidade crítica e dialética. 
Longe da afirmação de apresentar um instrumento ideal, espera-se que o presente estudo contribua na construção de uma ferramenta cujo conteúdo reflita o estado de arte para apoiar o cuidado na dimensão da família. 
REFERÊNCIAS 


\section{REFERÊNCIAS}

Abreu TFK, Amendola F, Trovo MM. Tecnologias relacionais como instrumentos para o cuidado na Estratégia de Saúde da Família. Rev Bras Enferm [Internet]. 2017 [citado 2018 out. 5]; 70(5):981-7. Disponível em: http://www.scielo.br/pdf/reben/v70n5/pt_0034-7167reben-70-05-0981.pdf. DOI: http://dx.doi.org/10.1590/0034-7167-2016-0337

Almeida MCP, Rocha SM, organizadoras. O trabalho de enfermagem. São Paulo: Cortez; 1997.

Alves MHL, Gasparello FJ. Cuidado de enfermagem com famílias - agregando um método para a aplicação da CIPR®. In: Cubas MR, Nóbrega MML, organizadoras. Atenção primária em saúde: diagnóstico, resultado e intervenções de enfermagem. Rio de Janeiro: Elsevier; 2015.

Backes DS, Colomé JS, Erdmannn RH, Lunardi VL. Grupo focal como técnica de coleta e análise de dados em pesquisa qualitativa. O Mundo da Saúde [Internet]. 2011; [citado 2018 out. 5];35(4):438-42. Disponível em:

http://bvsms.saude.gov.br/bvs/artigos/grupo_focal_como_tecnica_coleta_analise_dados_pesq uisa_qualitativa.pdf

Bíblia, A. T. Gênesis 1:28; 2:24. In: Bíblia. Português. Sagrada Bíblia Católica: Antigo e Novo Testamentos. Trad. de José Simão. São Paulo: Sociedade Bíblica de Aparecida; 2008.

Brasil. Conselho Nacional de Secretários de Saúde. As Conferências Nacionais de Saúde: Evolução e perspectivas. Brasília: CONASS; 2009. 100 p.

Brasil. Constituição, 1988. Constituição da República Federativa do Brasil. Brasília: Senado; 1988, 292 p.

Brasil. Decreto n. 7.508, de 28 de junho de 2011. Regulamenta a Lei no 8.080, de 19 de setembro de 1990, para dispor sobre a organização do Sistema Único de Saúde - SUS, o planejamento da saúde, a assistência à saúde e a articulação interfederativa, e dá outras providências. [Internet]. Brasília; 2011a [citado 2019 jan. 5]. Disponível em:

http://www.planalto.gov.br/ccivil_03/_Ato2011-2014/2011/Decreto/D7508.htm

Brasil. Lei n. 9.637, de 15 de maio de 1998. Dispõe sobre a qualificação de entidades como organizações sociais, a criação do Programa Nacional de Publicização, a extinção dos órgãos e entidades que menciona e a absorção de suas atividades por organizações sociais, e dá outras providências. Brasília; 1998a [citado 2017 jun. 5]. Disponível em: http://www.planalto.gov.br/ccivil_03/leis/19637.htm 
Brasil. Ministério da Administração Federal e Reforma do Estado. Secretaria da Reforma do Estado. Organizações sociais. Brasília: Ministério da Administração e Reforma do Estado; 1997. 74 p. (Cadernos MARE da reforma do estado; v. 2).

Brasil. Ministério da Saúde. Portaria n. 2.488, de 21 de outubro de 2011. Aprova a Política Nacional de Atenção Básica, estabelecendo a revisão de diretrizes e normas para a organização da Atenção Básica, para a Estratégia Saúde da Família (ESF) e o Programa de Agentes Comunitários de Saúde (PACS) [Internet]. Brasília; 2011b [citado 2019 jan. 5]. Disponível em: http://bvsms.saude.gov.br/bvs/saudelegis/gm/2011/prt2488_21_10_2011.html

Brasil. Ministério da Saúde. Saúde da Família. [Internet]. Brasília; 2019a. [citado 2019 jan. 5]. Disponível em: http://www.saude.gov.br/acoes-e-programas/forca-nacional-do-sus/comitegestor/772-acoes-e-programas/saude-da-familia/41285-saude-da-familia

Brasil. Ministério da Saúde. Secretaria de Atenção à Saúde. Departamento de Atenção Básica. Memórias da saúde da família no Brasil. Brasília: Ministério da Saúde; 2010a.

Brasil. Ministério da Saúde. Secretaria de Atenção à Saúde. Departamento de Atenção Básica. Política Nacional de Atenção Básica 4. ed. Brasília: Ministério da Saúde; 2007.

Brasil. Ministério da Saúde. Secretaria de Atenção à Saúde. Departamento de Atenção Básica. Diretrizes do NASF: Núcleo de Apoio a Saúde da Família. Brasília: Ministério da Saúde; 2010 b.

Brasil. Ministério da Saúde. Secretaria de Atenção à Saúde. Departamento de Atenção Básica. Política Nacional de Atenção Básica; Brasília: Ministério da Saúde; 2012.

Brasil. Ministério da Saúde. Sistema Único de Saúde (SUS): estrutura, princípios e como funciona. [Internet]. Brasília; 2019b. [citado 2019 jan. 5]. Disponível em: http://portalms.saude.gov.br/sistema-unico-de-saude

Brasil. Portaria n. 2.436, de 21 de setembro de 2017. Aprova a Política Nacional de Atenção Básica, estabelecendo a revisão de diretrizes para a organização da Atenção Básica, no âmbito do Sistema Único de Saúde (SUS). [Internet]. Brasília; 2017 [citado 2019 jan. 5]. Disponível em: http://bvsms.saude.gov.br/bvs/saudelegis/gm/2017/prt2436_22_09_2017.html

Brasil. Secretaria de Assistência à Saúde. Coordenação de Saúde da Comunidade. SIAB. Manual do sistema de informação de atenção básica Brasília: Ministério da Saúde; 1998b.

Bruschini C, Ridenti S. Família, casa e trabalho. Cad Pes. 1994;(88):30-6.

Bruschini C. Uma abordagem sociológica de família. Rev Bras Est Pop. 1989;6(1):1-23.

Buss PM, Pelegrini Filho A. A saúde e seus determinantes sociais. Physis. 2007;17(1):77-93. 
Campos CMS, Soares CB. Necessidades de Saúde e o cuidado de Enfermagem em Saúde Coletiva. Barueri: Manole; 2013.

Campos CMS. Reconhecimento das necessidades de saúde dos adolescentes. In: Borges ALV, Fujimori E. Enfermagem e a saúde do adolescente na atenção básica. Barueri: Manole; 2009. p. 142-67.

Chapadeiro CA, Okano HYSA, Araújo MRN. A família como foco da atenção primária à saúde. Versão Preliminar. Belo Horizonte: Nescon/UFMG; 2011. Ferramentas de abordagem familiar; p. 59-87.

Conselho Federal de Enfermagem - COFEN. Resolução Cofen n. 358/2009. Dispõe sobre a Sistematização da Assistência de Enfermagem e a implementação do Processo de Enfermagem em ambientes, públicos ou privados, em que ocorre o cuidado profissional de Enfermagem, e dá outras providências. [Internet]. Brasília; 2009 [citado 2019 jan. 5].

Disponível em: http://www.cofen.gov.br/resoluo-cofen-3582009_4384.html

Conselho Regional de Enfermagem de São Paulo - COREN-SP. Processo de enfermagem: guia para a prática. São Paulo: COREN-SP; 2015. 113 p.

Cubas MR, Egry EY. Classificação Internacional de Práticas de Enfermagem em Saúde Coletiva - CIPESC®. Rev Esc Enferm USP [Internet]. 2008 [citado 2019 jul. 14]; 42(1):1816. Disponível em: http://dx.doi.org/10.1590/S0080-62342008000100024

Cubas MR, Nóbrega MML, organizadoras. Atenção primária em saúde: diagnóstico, resultado e intervenções de enfermagem. Rio de Janeiro: Elsevier; 2015. 328 p.

Cunha SMB, Barros ALBL. Análise da implementação da Sistematização da Assistência de Enfermagem, segundo o Modelo Conceitual de Horta. Rev Bras Enferm. [Internet]. 2005 [citado 2018 fev. 13]; 58(5): 568-2. Disponível em: http://dx.doi.org/10.1590/S003471672005000500013

Edwards A. Working relationally in and across practices - a cultural-historical approach to collaboration. Cambridge: Cambridge University Press; 2017.

Egry EY, Fonseca RMGS. A família, a visita domiciliária e a enfermagem: revisitando o processo de trabalho da enfermagem em saúde coletiva. Rev Esc Enferm USP, 2000;34(3):339.

Egry EY, organizadora. As necessidades em saúde na perspectiva da atenção básica: guia para pesquisadores. São Paulo: Dedone; 2008. Metodologias para captação da realidade objetiva. p.79-90.

Elias PE, Ferreira CW, Alves MCG, Cohn A, Kishima V, Escrivão Junior A. Atenção Básica em Saúde: comparação entre PSF e UBS por estrato de exclusão social no município de São Paulo. Cienc Saude Colet. 2006;11(3):633-41. 
Engels F. A origem da família, da propriedade privada e do Estado [recurso eletrônico]. Trad. de Leandro Konder. Rio de Janeiro: BestBolso; 2017.

Engeström Y. Aprendizagem expansiva. Campinas: Pontes; 2016. 431 p.

Faco VMG, Melchiori LB. Conceito de família: adolescentes de zonas rural e urbana [Internet]. In: Valle, TGM, organizadora. Aprendizagem e desenvolvimento humano: avaliações e intervenções. São Paulo: Cultura Acadêmica; 2009. p. 121-35. Disponível em: http://books.scielo.org/id/krj5p/pdf/valle-9788598605999-07.pdf

Ferreira ABH. Dicionário Aurélio da língua portuguesa. São Paulo: Positivo; 2010. Família.

Ferreira SRS, Périco LAD, Dias VRGF. A complexidade do trabalho do enfermeiro na Atenção Primária à Saúde. Rev Bras Enferm [Internet]. 2018 [citado 2019 ago. 13]; 71(Supl 1):704-9. Disponível em: http://www.scielo.br/scielo.php?script=sci_arttext\&pid=S003471672018000700704\&lng=en. DOI: http://dx.doi.org/10.1590/0034-7167-2017-0471

Figueiredo EM. A Estratégia Saúde da Família na Atenção Básica do SUS [Internet]. UNASUS/UNIFESP; 2012. [citado 2019 jan. 5]. Disponível em: https://www.unasus.unifesp.br/biblioteca_virtual/esf/2/unidades_conteudos/unidade05/unidad e05.pdf

Figueiredo MHJS. Enfermagem de Família: um contexto do cuidar. [dissertação] Porto: Instituto de Ciências Biomédicas Abel Salazar - Universidade do Porto; 2009.

Fiore DC, Duarte TSB. Porque atentar à gestão de pessoas nas organizações sociais? Reflexões a partir do estado. In: Anais do $7^{\circ}$ Congresso CONSAD de Gestão Pública, 2014; mar. 25-27. Brasília. Brasília: CONSAD; 2014. Disponível em: http://portal.saude.sp.gov.br/resources/ses/perfil/profissional-dasaude/destaques//por_que_atentar_a_gestao_de_pessoas_nas_os_2014_versao_publicada_con sad.pdf

Fitzsimmons JA, Fitzsimmons MJ. Administração de serviços: operações, estratégia e tecnologia da informação. 7 ed. Porto Alegre: Mc Graw Hill Education; 2014.

Fundação Sistema Estadual de Análise de dados - SEADE. [Internet]. São Paulo; 2018. [citado 2018 maio. 31]. Disponível em: http://www.seade.gov.br/

Gomes MA, Pereira MLD. Família em situação de vulnerabilidade social: uma questão de políticas públicas. Cien Saude Colet. 2005;10(2):113-28.

Gonçalves RBM. Práticas de Saúde: processos de trabalho e necessidades. São Paulo: CEFOR; 1992. (Cadernos CEFOR, 1 -Série textos).

Gondim GMM. Territórios da atenção básica: múltiplos, singulares ou inexistentes? [tese]. Rio de Janeiro: Escola Nacional de Saúde Pública Sergio Arouca; 2011. Disponível em: https://www.arca.fiocruz.br/bitstream/icict/17935/1/1118.pdf 
Heller A. Teoria de las necesidades em Marx. 2. ed. Barcelona: Peninsola, 1986.

Instituto Brasileiro de Geografia e Estatística - IBGE. População [Internet]. Brasília [s.d]. [citado 2017 jul. 28]. Disponível em: https://www.ibge.gov.br/estatisticas/sociais/populacao.html

Itaboraí NR. Mudança nas famílias brasileiras (1976 - 2012): uma perspectiva de classe e gênero [tese]. Rio de Janeiro: Instituto de Estudos Sociais e Políticos, Universidade do Estado de Rio de Janeiro; 2015.

Lanssoni FZ. A Sistematização da Assistência de Enfermagem (SAE): Dificuldades para sua implantação e operacionalização. In: Anais do $16^{\circ}$ Congresso de Iniciação Científica UNIMEP; 2008 set 30 - out 2; Piracicaba. Piracicaba: UNIMEP; 2008. [citado 2018 fev. 13]. Disponível em: http://www.unimep.br/phpg/mostraacademica/anais/6mostra/1/385.pdf

Leite de Barros ALB, Lopes JL. leitede enfermagem. Enfermagem em Foco [Internet]. 2010 [citado 2018 out. 5]; 1(2):63-5. Disponível em: http://revista.cofen.gov.br/index.php/enfermagem/article/viewFile/17/18

Martins JJ, Albuquerque GL. A utilização de tecnologias relacionais como estratégia de humanização do processo de trabalho em saúde. Cienc Cuid Saúde. 2007;6(3):351-6.

Mello DF, Viera CS, Simpionato E, Biasoli-Alves ZMM, Nascimento LC. Genograma e Ecomapa: possibilidades de utilização na estratégia de saúde da família. Rev Bras Cresc Desenv Hum [Internet]. 2005 [citado 2018 out. 5]; 15(1):78-89. Disponível em: http://pepsic.bvsalud.org/pdf/rbcdh/v15n1/09.pdf

Mendes EV. O cuidado das condições crônicas na atenção primária à saúde: o imperativo da consolidação da estratégia da saúde da família. Brasília: Organização Pan-Americana da Saúde; 2012.

Merhy EE, Onocko R. Agir em saúde: um desafio para o público. 2 ed. São Paulo: Hucitec; 2006. 385 p.

Minayo MCS. O desafio do conhecimento: pesquisa qualitativa em saúde. 7 ed. São Paulo: Hucitec; 2000.

Minuchin P. Families and individual development: provocations from the field of family therapy. Child Development, 1985;56:289-302.

Miranda LCV, Silveira MR, Chianca TCM, Vaz RMF. Sistematização da assistência de enfermagem na atenção primária à saúde: um relato de experiência. Rev enferm UFPE on line [Internet]. 2013 [citado 2018 out. 5]; 7(1):295-301, Disponível em: DOI: 10.5205/reuol.304924704-1-LE.0701201338

Morais HMM, Albuquerque MSV, Oliveira RS, Cazuzu AKI, Silva NAF. Organizações Sociais da Saúde: uma expressão fenomênica da privatização da saúde no Brasil. Cad Saude Publica [Internet]. 2018 [citado 2019 abr. 25];34(1):e00194916. Disponível em: 
http://www.scielo.br/scielo.php?script=sci_arttext\&pid=S0102-

311X2018000105017\&lng=pt\&nrm=iso. DOI: http://dx.doi.org/10.1590/0102-

$311 \times 00194916$.

Morgan DL. Focus group as qualitative research. London: Sage; 1997.

Morgan LH. Ancient Society. [Internet]. 2004. [citado 2018 dez. 5]. Disponível em: https://www.marxists.org/reference/archive/morgan-lewis/ancient-society/

NANDA International. Diagnósticos de enfermagem da NANDA-I: definições e classificação 2018-2020 [recurso eletrônico]. Trad. de Regina Machado Garcez; Revisão técnica de Alba Lucia Bottura Leite de Barros, Anamaria Alves Napoleão, Diná de Almeida Lopes Monteiro da Cruz, Marta José Avena, Virginia Visconde Brasil, 11. ed. Porto Alegre: Artmed; 2018.

Neves RS, Shimizui HE. Análise da implementação da Sistematização da Assistência de Enfermagem em uma unidade de reabilitação. Rev Bras Enferm [Internet]. 2010 [citado 2018 fev. 13]; 63(2):222-9. Disponível em: http://www.scielo.br/pdf/reben/v63n2/09

Oliveira CM, Carvalho DV, Peixoto ERM, Camelo LV, Salviano MEM. Percepção da equipe de enfermagem sobre a implementação do processo de enfermagem em uma unidade de um hospital universitário. Rev Min Enferm [Internet]. 2012 [citado 2018 fev. 13]; 16(2):258-63. Disponível em: http://reme.org.br/content/imagebank/pdf/v16n2a15.pdf

Patton MQ. Qualitative evaluation and research methods. 2 ed. Thousand Oaks: Sage; 1990.

Paula M, Peres AM, Bernardino E, Eduardo EA, Sade PMC, Larocca LM. Características do processo de trabalho do enfermeiro da estratégia de saúde da família. Rev Min Enferm [Internet]. 2014 [citado 2018 out. 5]; 18(2):463-70. Disponível em: http://www.dx.doi.org/10.5935/1415-2762.20140034

Peduzzi M, Anselmi ML. O processo de trabalho de enfermagem: a cisão entre planejamento e execução do cuidado. Rev Bras Enferm. [Internet]. 2002 [citado 2019 jul. 6]; 55(4): 392-8. Disponível em: http://www.scielo.br/pdf/reben/v55n4/v55n4a06.pdf

Peduzzi M. A inserção do enfermeiro na equipe de saúde da família na perspectiva da promoção da saúde. In: Anais do $1^{\circ}$ Seminário Estadual - O enfermeiro no programa Saúde da Família, 2002; São Paulo. São Paulo: Secretaria de Estado da Saúde; 2000.

Pinheiro R, Mattos RA, organizadores. Os sentidos da integralidade na atenção e no cuidado à saúde. Rio de Janeiro: UERJ, IMS: ABRASCO; 2001. 184 p.

Programa Saúde da Família. Rev Saude Publica [Internet]. 2000 June [citado 2019 abr. 24]; 34(3):316-9. Disponível em: http://www.scielo.br/scielo.php?script=sci_arttext\&pid=S003489102000000300018\&lng=en. DOI: http://dx.doi.org/10.1590/S0034-89102000000300018

Queiroz VM, Egry EY. Bases metodológicas para a assistência de enfermagem em saúde coletiva, fundamentadas no materialismo histórico e dialético. Rev Bras Enferm. [Internet]. 
1988 [citado 2018 jun. 26]; 41(1):26-33. Disponível em: http://www.scielo.br/pdf/reben/v41n1/v41n1a05.pdf. DOI: http://dx.doi.org/10.1590/S003471671988000100005

Ribeiro ME. As várias abordagens da família no cenário do programa/estratégia de saúde da família (PSF). Rev Latino-Am Enfermagem [Internet]. 2004 [citado 2018 out. 5];12(4):65864. Disponível em: http://www.scielo.br/pdf/rlae/v12n4/v12n4a12.pdf

Sanna MC. Os processos de trabalho na Enfermagem. Rev Bras Enferm [Internet]. 2007 [citado 2018 out. 5];60(2):221-4. Disponível em: http://www.scielo.br/pdf/reben/v60n2/a17v60n2.pdf

São Paulo (Cidade) Classificação Internacional das Práticas de Enfermagem em Saúde Coletiva. São Paulo: PMSP. [s.d.].

São Paulo (Cidade). Estratégia Saúde da Família - ESF. [Internet]. São Paulo; 2013. [citado 2019 jan. 5]. Disponível em: http://www.capital.sp.gov.br/cidadao/saude-e-bemestar/melhorias-na-saude-municipal/estrategia-saude-da-familia-esf

São Paulo (Cidade). Fortalecendo a Atenção Básica no Município de São Paulo - Diretrizes Operacionais. [Internet]. São Paulo; 2015. [citado 2019 jan. 5]. Disponível em: https://www.prefeitura.sp.gov.br/cidade/secretarias/upload/saude/Documentosdiretrizesversao revisada201015diagramadobaixaATUALIZADA(1).pdf

São Paulo (Cidade). Histórico do Campo Limpo. [Internet]. São Paulo; 2017. [citado 2019 jan. 5]. Disponível em:

https://www.prefeitura.sp.gov.br/cidade/secretarias/subprefeituras/campo_limpo/historico/ind ex.php? $=131$

São Paulo (Cidade). Rede Assistencial do Distrito Administrativo Jardim Angela da Supervisão Técnica da Saúde M’Boi Mirim e do Distrito Administrativo Capão Redondo da Supervisão Técnica de Saúde Campo Limpo. [Internet]. São Paulo; 2014. [citado 2019 jan. 5]. Disponível em: https://www.prefeitura.sp.gov.br/cidade/secretarias/upload/saude/CG_R0062015_compressed.pdf

São Paulo (Estado). Lei Complementar n. 846, de 4 de junho de 1998. Dispõe sobre a qualificação de entidades como organizações sociais e dá outras providências. São Paulo; 1998 [citado 2017 jun. 5]. Disponível em:

https://www.al.sp.gov.br/repositorio/legislacao/lei.complementar/1998/lei.complementar-84604.06.1998.html

Scarre C. The Penguin Historical Atlas of Ancient Rome. London: Penguin Books; 1995.

Silva EGC, Oliveira VC, Neves GBC, Guimarães TMR. O conhecimento do enfermeiro sobre a Sistematização da Assistência de Enfermagem: da teoria à prática. Rev Esc Enferm USP [Internet]. 2011 [citado 2018 out. 5];45(6):1380-6. Disponível em: http://www.scielo.br/pdf/reeusp/v45n6/v45n6a15.pdf 2017 
Silva MCLSR, Silva L, Bousso RS. A abordagem à família na Estratégia de Saúde da Família: uma revisão integrativa da literatura. Rev Esc Enferm USP [Internet]. 2011; [citado 2018 out. 5]; 45(5):1250-5. Disponível em: http://www.scielo.br/pdf/reeusp/v45n5/v45n5a31.pdf

Soratto J, Pires DEP, Dornelles S, Lorenzetti J. Estratégia Saúde Da Família: uma inovação tecnológica em saúde. Texto Contexto Enferm, 2015 [citado 2018 out. 5]; 24(2): 584-92. Disponível em: http://www.scielo.br/pdf/tce/v24n2/pt_0104-0707-tce-24-02-00584.pdf. DOI: http://dx.doi.org/10.1590/0104-07072015001572014

Tanaka LH, Santana CLA. Grupo focal como importante ferramenta de pesquisa participativa em saúde. In: Toledo RF, Rosa TEC, Keinet TM, Cortizo CT, organizadores. Pesquisa participativa em saúde: vertentes e veredas. São Paulo: Instituto da Saúde; 2018. p. 203-9.

Trad LAB. Grupos focais: conceitos, procedimentos e reflexões baseadas em experiências com o uso da técnica em pesquisas de saúde. Physis [Internet]. 2009; [citado 2019 abr. 26]; 19(3):777-96. Disponível em: http://www.scielo.br/pdf/physis/v19n3/a13v19n3.pdf. DOI: http://dx.doi.org/10.1590/S0103-73312009000300013

Vigotskii LS, Luria AR, Leontiev AN. Linguagem, Desenvolvimento e Aprendizagem. Trad. de Maria da Pena Villalobos. 11 ed. São Paulo: Ícone; 2010.

Virkkunen J, Newnham DS. O laboratório de mudança: uma ferramenta de desenvolvimento colaborativo para o trabalho e a educação. Belo Horizonte: Fabrefractum; 2015.

Vygotsky LS. Pensamento e linguagem. São Paulo: Martins Fontes; 1998.

Wernet M, Angelo M. Mobilizando-se para a família: dando um novo sentido à família e ao cuidar [Internet]. 2003 [citado 2018 out. 5];37(1):19-25. Disponível em: https://www.nescon.medicina.ufmg.br/biblioteca/imagem/0181.pdf

Wright LM, Leahey M. Enfermeiras e famílias: guias para avaliação e intervenção na família. 5 ed. São Paulo: Roca; 2012.

Zanella LCH. Metodologia de pesquisa. 2. ed. Florianópolis: Departamento de Ciências da Administração/UFSC; 2013.

Zoboli ELP, Fracolli LA, Chiesa AM. O cuidado de enfermagem em saúde coletiva. In:

Soares CB, Campos CMS. Fundamentos de saúde coletiva e cuidado de enfermagem. Barueri: Manole; 2013. p. 244-64. 
APÊNDICES 


\section{APÊNDICES}

\section{APÊNDICE 1 - TERMO DE CONSENTIMENTO LIVRE E ESCLARECIDO - PROFISSIONAL}

Convidamos o Sr. (a) a participar da pesquisa intitulada "Instrumento para a abordagem familiar na Estratégia Saúde da Família: potencialidades para o cuidado do enfermeiro desenvolvida pelas Sra. Alessandra Cristina Ferreira Martins e Sra. Natália Rodrigues Mosca.

O motivo que nos leva a estudar a Sistematização da Assistência de Enfermagem com abordagem Familiar, é a necessidade de identificar as demandas da família, levando em consideração seus simbolismos, organização, dinâmica, inserção social e demais especificidades. A disciplina de AB (Atenção Básica) da EEUSP (Escola de Enfermagem da Universidade de São Paulo) formulou um instrumento pedagógico de sistematização do cuidado de enfermagem à família, que vem sendo utilizado junto aos estudantes de graduação e precisa ser aplicado às famílias, pelos profissionais enfermeiros para testar sua potencialidade. $\mathrm{O}$ objetivo desse estudo é testar as potencialidades e limites de um instrumento de sistematização da assistência de enfermagem à família na APS.

Sua participação nesta pesquisa limitar-se-á a participação de duas oficinas (inicial e final) e aplicação do Instrumento de Apoio para Elaboração do Projeto de Cuidado à Família em duas famílias assistidas por você, durante sua rotina de atendimento e o preenchimento do diário de campo. Sua participação trará como benefício, a adaptação de um instrumento que auxiliará os enfermeiros na elaboração da SAE familiar, qualificando o cuidado para as famílias que são atendidas pela ESF.

Os riscos da pesquisa estão relacionados a possíveis alterações na rotina do trabalho para a aplicação do instrumento proposto.

Após ser esclarecido (a) sobre essas informações, e no caso de aceitar fazer parte do estudo, você deverá assinar as duas vias deste documento. Uma delas será destinada a você e a outra as pesquisadoras responsáveis. Todas as páginas deverão ser rubricadas.

As oficinas serão realizadas em uma Unidade Básica de Saúde do território de fácil acesso a todos os participantes, durante o horário de trabalho, com a autorização do gestor da unidade de origem de cada participante. Caso tenha alguma despesa decorrente de sua participação na pesquisa, será ressarcido pelas pesquisadoras. 
Você tem direito a garantia de indenização caso sejam comprovados danos recorrentes da participação da pesquisa.

Em qualquer etapa do estudo, você terá acesso às pesquisadoras responsáveis pela investigação para esclarecimento de dúvidas. As principais pesquisadoras são a Sra. Alessandra Cristina Ferreira Martins que pode de ser encontrada no endereço Rua Antonio de Barros, 2650, Tatuapé - SP, Telefone: (11) 99581-4185 e-mail: acristina@ usp.br e a Sra.Natália Rodrigues Mosca que pode ser encontrada no endereço Estrada do Capuava, 4117 - Cotia - SP. Telefone: (11) 99363-1694 e-mail: natalia.rm@usp.br.

Caso você tenha alguma consideração ou dúvida sobre a ética da pesquisa, entre em contato com o Comitê de Ética em Pesquisa (CEP) - Endereço - Av. Dr. Enéas de Carvalho Aguiar, 419 - Cerqueira Cesar - São Paulo/SP CEP - 05403-000 Telefone- (11) 30618858 email-cepee@usp.br

Esta pesquisa atende todas as especificações da Resolução 466, de 12 de dezembro de 2012 que aprova as diretrizes e normas regulamentadoras de pesquisas envolvendo seres humanos.

Assinatura do pesquisador

Assinatura do participante

Data. . 1 


\section{APÊNDICE 2 - TERMO DE CONSENTIMENTO LIVRE E ESCLARECIDO - FAMÍLIA}

Convidamos o Sr. (a) a participar da pesquisa intitulada "Instrumento para a abordagem familiar na Estratégia Saúde da Família: potencialidades para o cuidado do enfermeiro desenvolvida pelas Sra. Alessandra Cristina Ferreira Martins e Sra. Natália Rodrigues Mosca.

O motivo que nos leva a estudar a Sistematização da Assistência de Enfermagem com abordagem Familiar, é a necessidade de identificar as demandas da família, levando em consideração seus simbolismos, organização, dinâmica, inserção social e demais especificidades. A disciplina de AB (Atenção Básica) da EEUSP (Escola de Enfermagem da Universidade de São Paulo) formulou um instrumento pedagógico de sistematização do cuidado de enfermagem à família, que vem sendo utilizado junto aos estudantes de graduação e precisa ser aplicado às famílias, pelos profissionais enfermeiros para testar sua potencialidade. $\mathrm{O}$ objetivo desse estudo é testar as potencialidades e limites de um instrumento de sistematização da assistência de enfermagem à família na APS.

Sua participação nesta pesquisa limitar-se-á a responder um Instrumento de Apoio para Elaboração do Projeto de Cuidado à Família, que será testado com o objetivo de identificar a percepção dos enfermeiros em relação a reconhecer as necessidades de saúde da sua família.

Sua participação é voluntária, caso não deseje participar desta pesquisa, não haverá nenhum prejuízo em relação à assistência prestada a você e sua família.

O tempo estimado para resposta do instrumento é de aproximadamente 15 minutos. Seus dados serão preservados e não serão utilizados.

Após ser esclarecido (a) sobre essas informações, e no caso de aceitar fazer parte do estudo, você deverá assinar as duas vias deste documento. Uma delas será destinada a você e a outra as pesquisadoras responsáveis. Todas as páginas deverão ser rubricadas.

Você tem direito a garantia de indenização caso sejam comprovados danos recorrentes da participação da pesquisa.

Em qualquer etapa do estudo, você terá acesso às pesquisadoras responsáveis pela investigação para esclarecimento de dúvidas. As principais pesquisadoras são a Sra. Alessandra Cristina Ferreira Martins que pode de ser encontrada no endereço Rua Antonio de Barros, 2650, Tatuapé - SP, Telefone: (11) 99581-4185 e-mail: acristina@ usp.br e a Sra.Natália Rodrigues Mosca que pode ser encontrada no endereço Estrada do Capuava, 4117 - Cotia - SP. Telefone: (11) 99363-1694 e-mail: natalia.rm@usp.br.

Caso você tenha alguma consideração ou dúvida sobre a ética da pesquisa, entre em 
contato com o Comitê de Ética em Pesquisa (CEP) - Endereço - Av. Dr. Enéas de Carvalho Aguiar, 419 - Cerqueira Cesar - São Paulo/SP CEP - 05403-000 Telefone- (11) 30618858 email-cepee@usp.br

Esta pesquisa atende todas as especificações da Resolução 466, de 12 de dezembro de 2012 que aprova as diretrizes e normas regulamentadoras de pesquisas envolvendo seres humanos.

Assinatura do pesquisador

Assinatura do participante

Data.

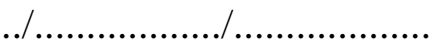




\section{APÊNDICE 3 - INSTRUMENTO DE APOIO PARA ELABORAÇÃO DO PLANO DE CUIDADO À FAMÍLIA (ADAPTADO)}

Instrumento de Apoio para elaboração do Prjeto de Cuidado à Família

Nome: № Prontuário

O instrumento foi aplicado durante: ( )Consulta na UBS ( )Visita Domiciliar ( )Grupo ( )Outros? Histórico

1. Dados gerais sobre a composição familiar:

Quem mora no domicilio?

\section{Quem são considerados os responsáveis financeiros pela família:}

3. Qual é a origem da renda da família?

Benefício do governo ( ) trabalho formal ( ) trabalho informal ( )

4. Você identifica alguma situação na sua casa que coloque a sua família em risco? $\operatorname{Sim}$ ( ) Não ( ) Qual?

\section{Alguém na sua casa sente medo de:}

Desmoronamento () Enchente ()

Contato com vetores, insetos e ratos ( )

6. Caso sua família precise de ajuda no bairro vocês costumam contar com:

Serviços social de alguma instituição ( ) Qual?

7. Dinâmica familiar (dimensão particular: relações entre os membros da família - potenciais de

fortalecimento e desgaste) Como é a rotina da sua casa?

Como a família se organiza no dia a dia? Há membros em creches, escolas ou faculdades?

8. Faça o Genograma e Ecomapa da família. 
Instrumento de Apoio para elaboração do Prjeto de Cuidado à Família

DIAGNÓSTICO

Liste os principais pontos de fortalecimentos e desgaste da família.

Diagnóstico de Enfermagem:

\begin{tabular}{|l|l|}
\hline FORTALECIMENTO & DESGASTE \\
\hline & \\
\hline & \\
\hline & \\
\hline & \\
\hline & \\
\hline & \\
\hline
\end{tabular}

*Diagnóstico de Enfermagem:

(*Tabela de apoio para consulta aos diagnósticos no impresso anexo)

Plano de Cuidado

Elaborar o plano de cuidados para a família com base nas necessidades de saúde identificadas. 


\section{APÊNDICE 4 - MATERIAL DE APOIO PARA CONSULTA}

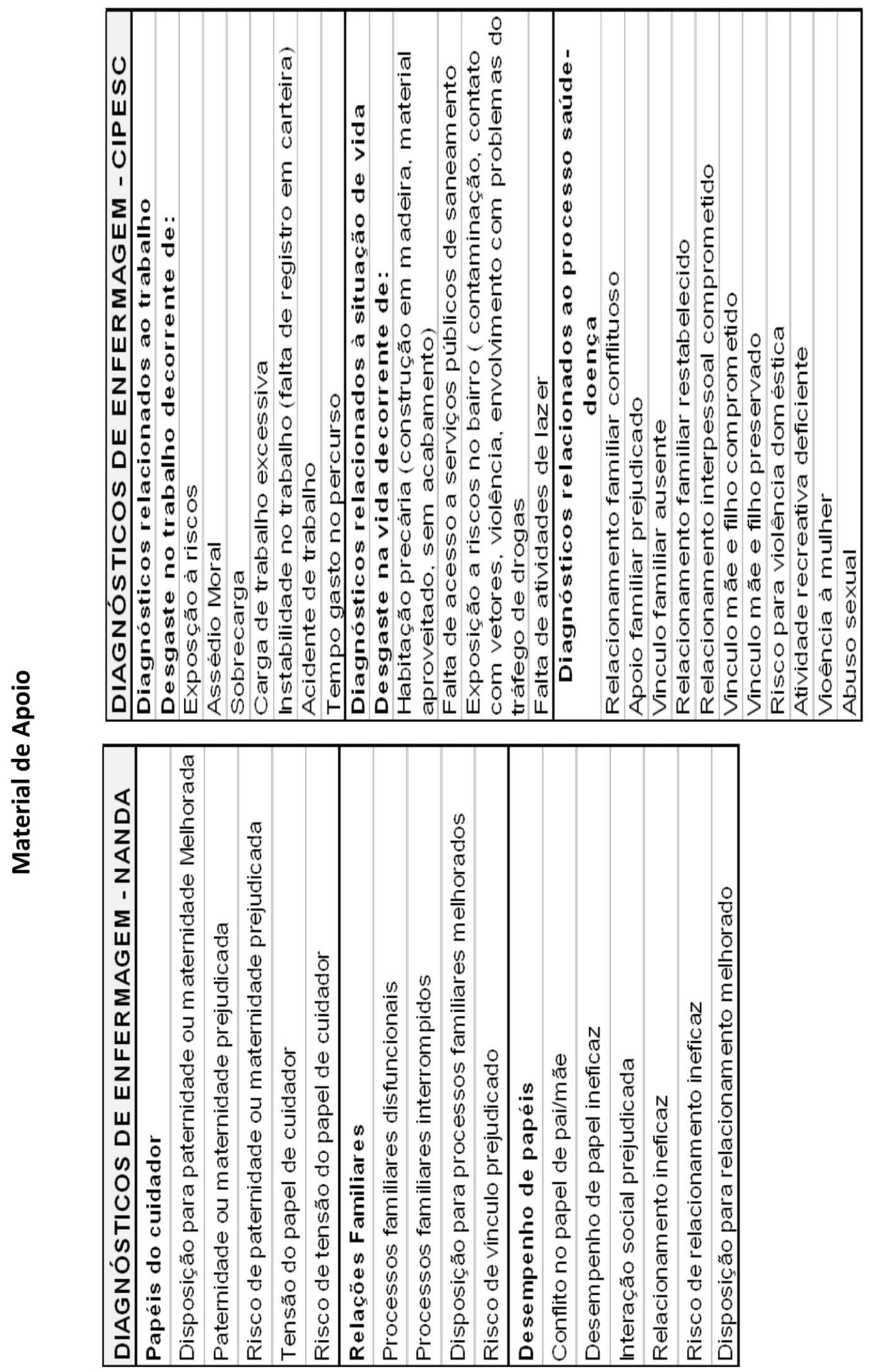




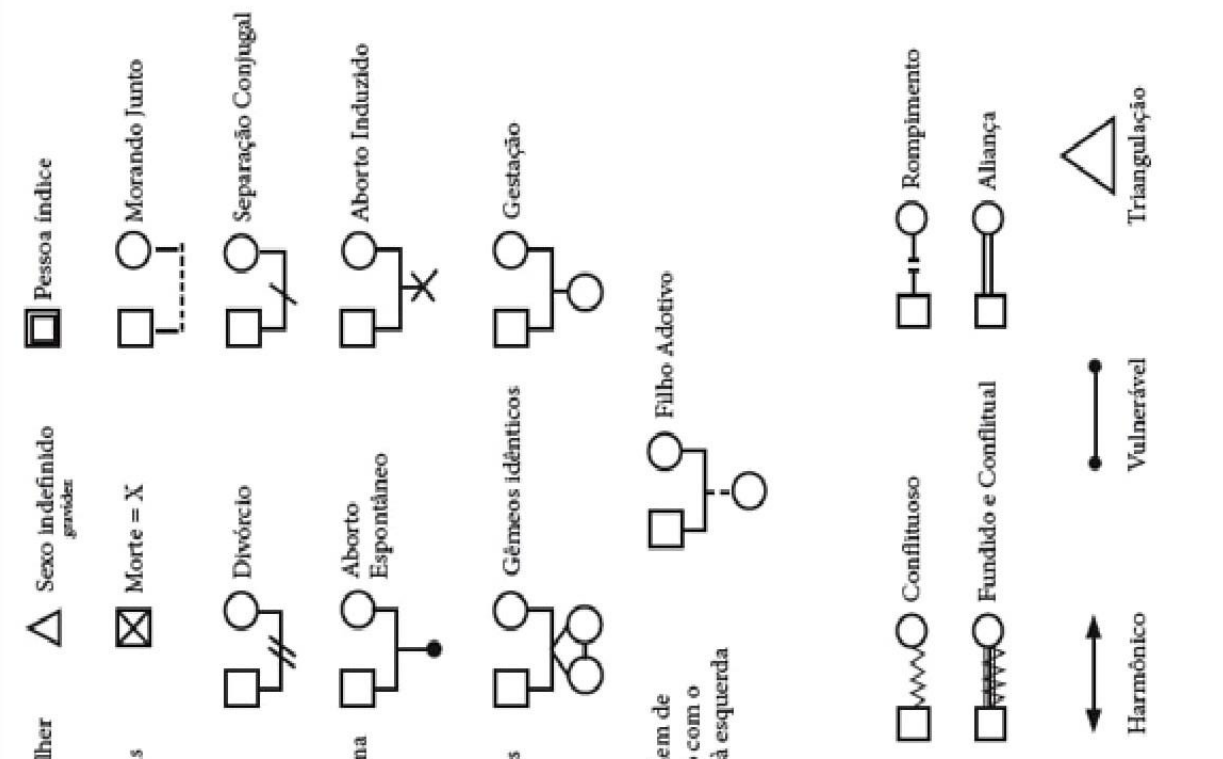

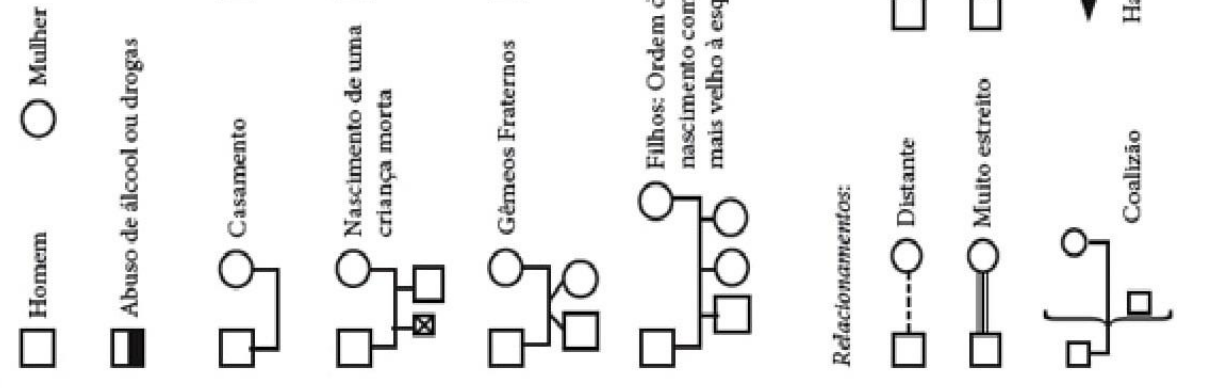

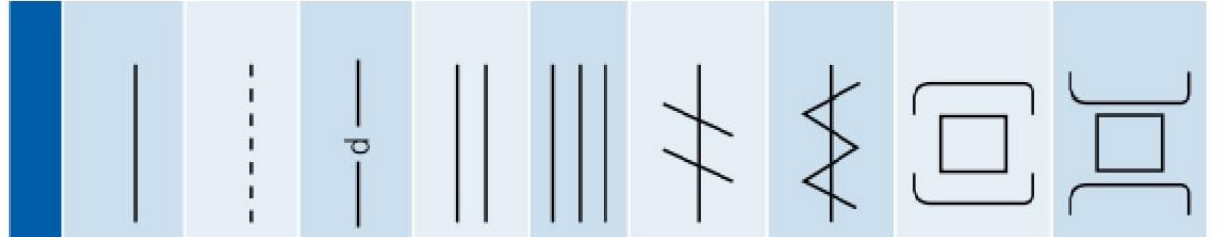

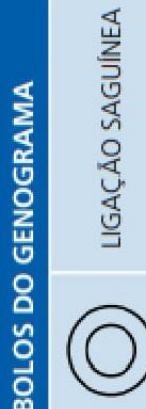

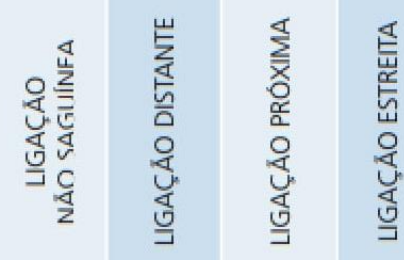

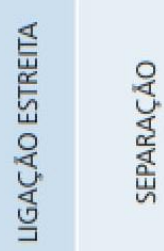

墨繁

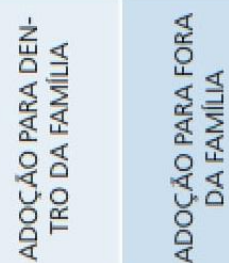

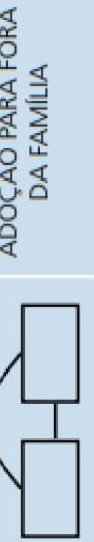

흔 $\quad \frac{\pi}{2}$

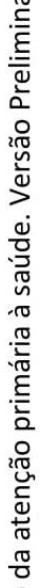

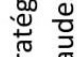

范

> $\quad$ i⿱

윰

(o)

तु

릉

ণ্

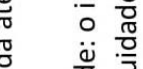

ชั

용

원

뜰 छे

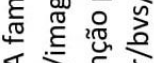

之. $\sum$ 资

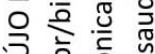

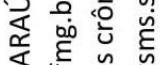
运责㟔

iा

خ 흫

I है

잋 ह

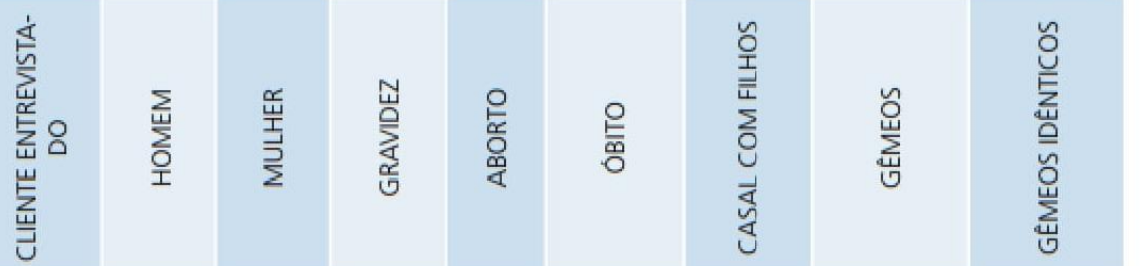
赔

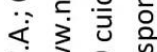
ن 0 \% ำㄴำ 崩员

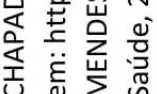




\section{APÊNDICE 5 - CARACTERIZAÇÃO DO PROFISSIONAL}

Instrumento de Apoio para elaboração do Prjeto de Cuidado à Família Caracterização do Profissional

Nome:

Idade:

Possui quanto tempo de formação?

Possui especialização ou residência em saúde da família? ( )Sim ( )Não

Atua como Enfermeiro de ESF há quanto tempo?

Há quanto tempo está com Enfermeiro desta equipe?

Quais foram as suas impressões e sugestões na aplicação deste instrumento? 


\section{APÊNDICE 6 - PRODUTO TÉCNICO}

INSTRUMENTO DE APOIO PARA O CUIDADO À FAMÍLIA - IAPCFAM

Instrumento de apoio para o cuidado à família - IAPCFam

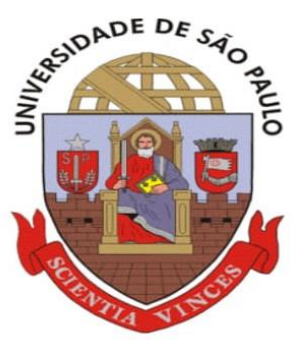

UBS:

Prontuário familiar
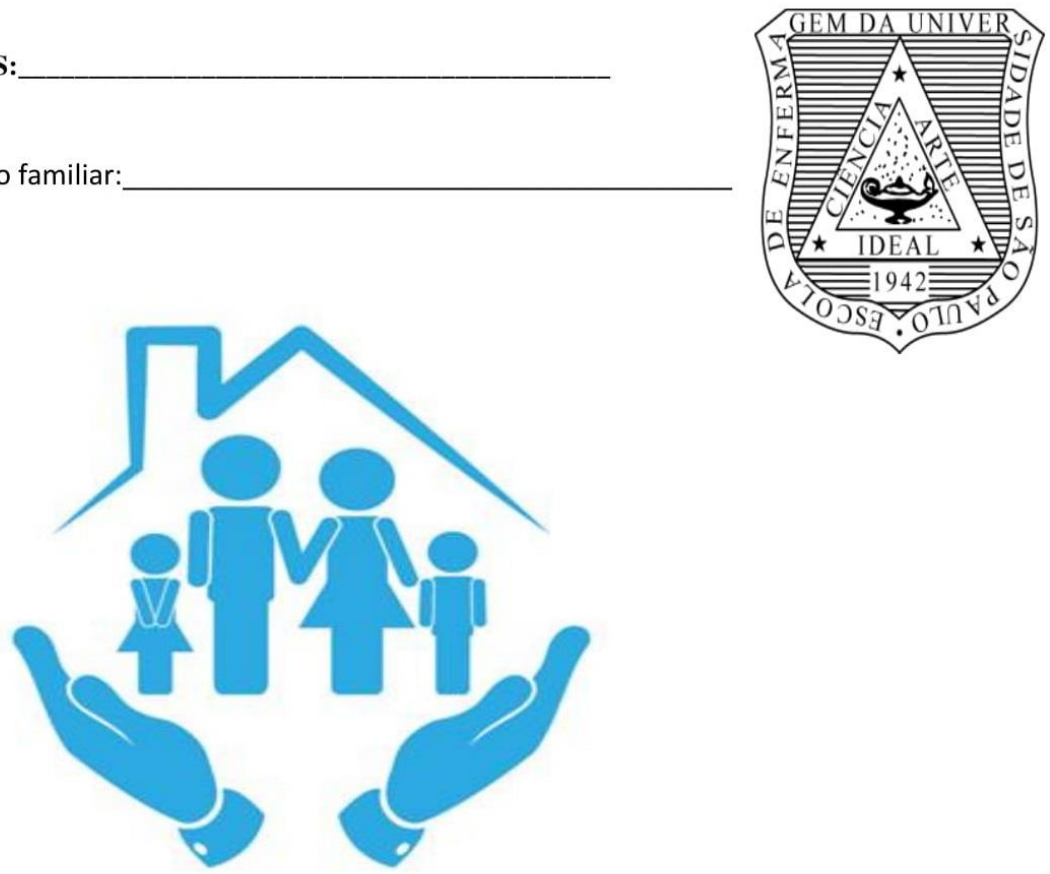

$\begin{array}{ll}\text { data: } & \text { nome: } \\ \text { data: } & \text { nome: } \\ \text { data: } & \text { nome: } \\ \text { data: } & \text { nome: } \\ \text { data: } & \text { nome: } \\ \text { data: } & \text { nome: } \\ \text { data: } & \text { nome: } \\ \text { data: } & \text { nome: } \\ \text { data: } & \text { nome: } \\ \text { data: } & \text { nome: } \\ \text { data: } & \text { nome: } \\ \text { data: } & \text { nome: } \\ \text { data: } & \text { nome: } \\ \text { data: } & \text { nome: } \\ \text { data: } & \text { nome: }\end{array}$

Orientamos a consulta prévia do cadastro e prontuário familiar disponível na unidade para o preenchimento do instrumento

\footnotetext{
* Tabela de apoio para consulta no impresso anexo
} 


\section{Instrumento de apoio para o cuidado à família - IAPCFam}

Histórico, estrutura e dinâmica familiar

1. Dados gerais da composição familiar

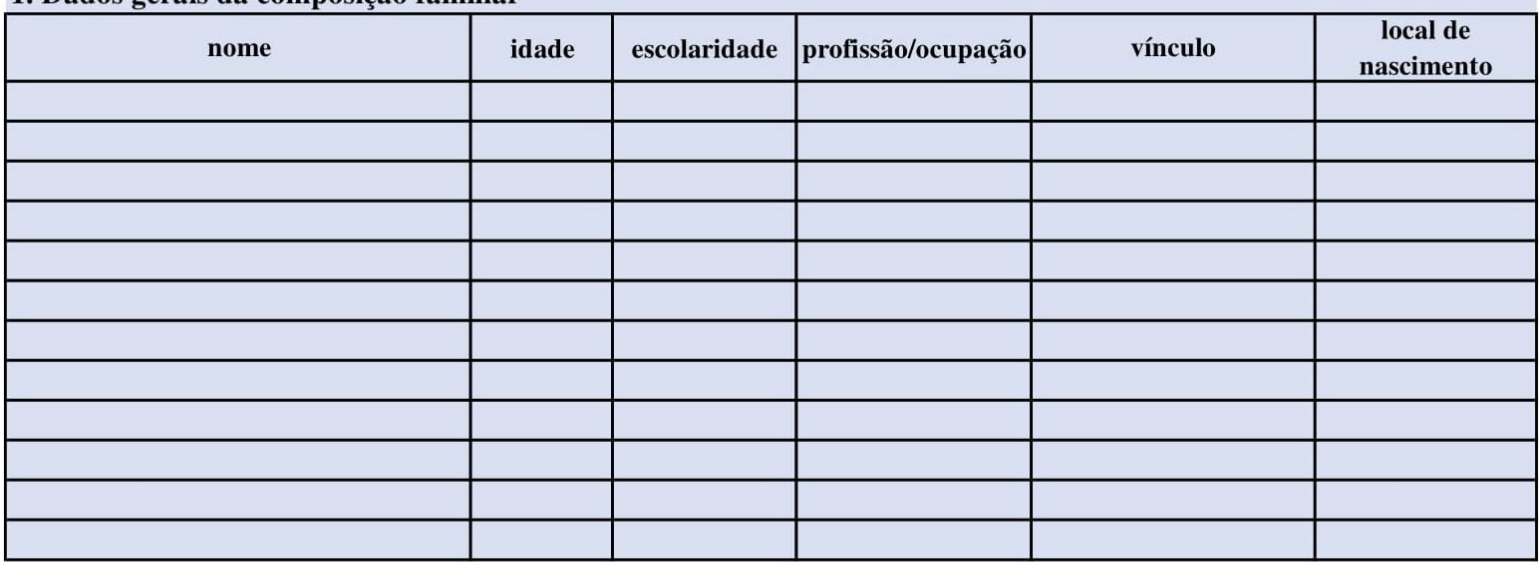

2. Estágio de ciclo de vida familiar atual:

saindo de casa ( ) compromisso com seu parceiro (a) ( ) aprender a viver junto ( ) chegada do primeiro filho ( ) vivendo com pré-escolares ( ) vivendo com adolescentes ( ) saída dos filhos ( ) velhice ( )

3. Desenho do genograma e ecomapa da família. *espaço disponível na contra-capa (consulte material de apoio 1)

4. Casa: própria ( ) alugada ( ) cedida ( )

5. Infraestrutura de moradia: água encanada ( ) esgoto ( ) coleta de lixo/resíduo ( ) energia elétrica ( )

6. No processo de ajuda sua família conta com:

ONG ( ) instituições governamentais ( ) instituições religiosas ( ) outros ( ):

7. Forma de acesso ao processo de ajuda familiar:

carta ( ) e-mail ( ) celular/whatsapp ( ) outros meios ( ):

8. Inserção da família em programa de benefício governamental:

não ( ) $\operatorname{sim}($ ) qual?

9. Ambiente em torno da casa apresenta risco de: não ( ) $\operatorname{sim}(\quad)$

desmoronamento ( ) enchente ( ) acidente de trânsito ( ) contaminação com lixo/esgoto ( ) contato com vetores, insetos, ratos ( ) ameaça por tráfico de drogas ( ) outros ( )

10. Descrição da organização/rotina familiar no dia a dia (trabalho, escola, atividades domésticas)

11. O que gostaria de mudar na sua rotina familiar?:

* Tabela de apoio para consulta no impresso anexo 
Instrumento de apoio para o cuidado à família - IAPCFam

\begin{tabular}{|l|l|}
\hline \multicolumn{2}{|c|}{ Síntese da capacidade familiar } \\
\hline fortalecimento & \\
\hline & \\
\hline & \\
\hline & \\
\hline & \\
\hline & \\
\hline
\end{tabular}

* Diagnóstico de enfermagem familiar: (consulte material de apoio 2)

Plano de intervenção familiar

Elaborar o plano de cuidados para a família com base nas necessidades de saúde identificadas (consulte material de apoio 3)

Acompanhamento e evolução familiar 


\section{APÊNDICE 7 - MATERIAL DE APOIO PARA CONSULTA FINALIZADO}

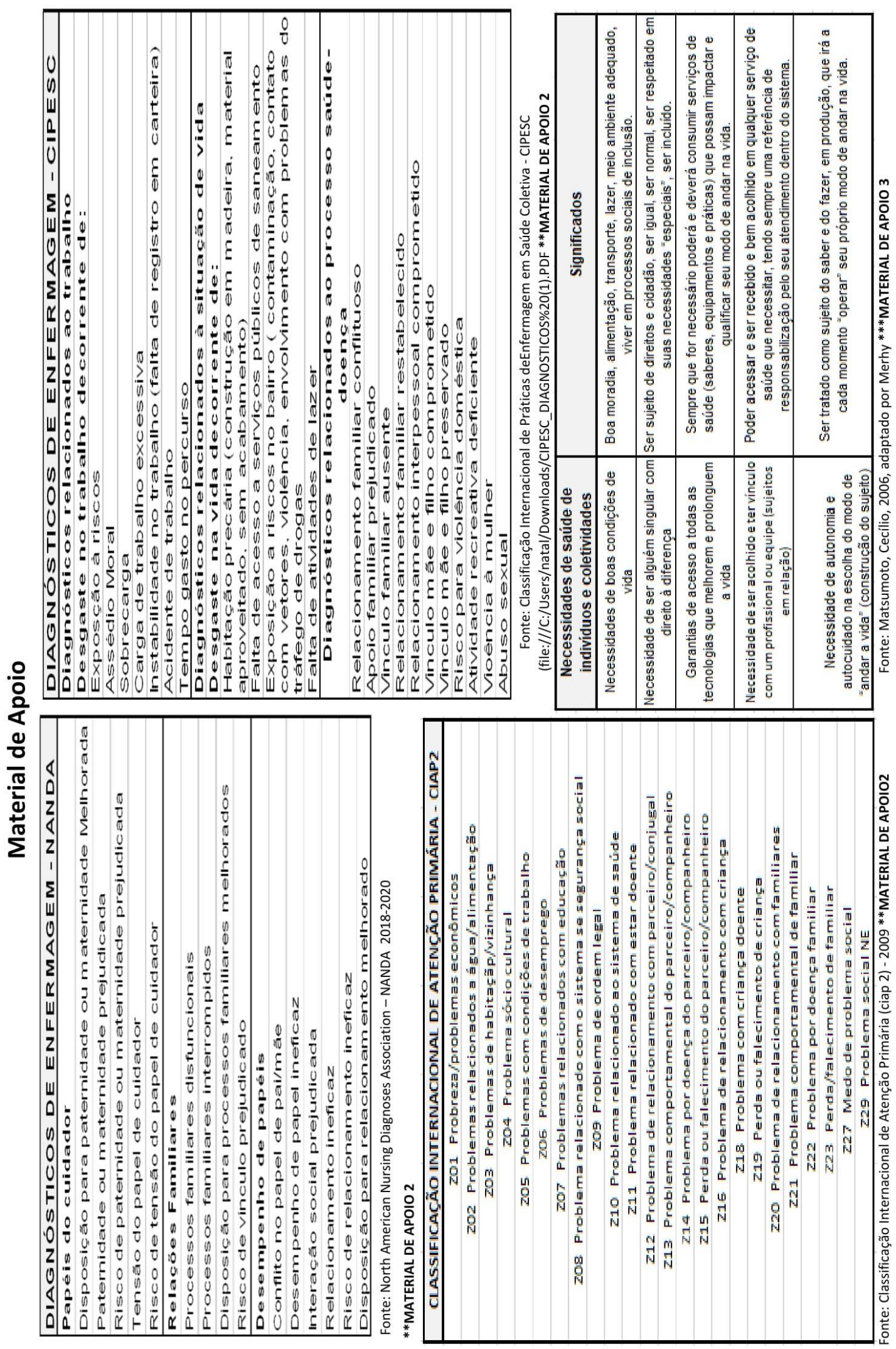



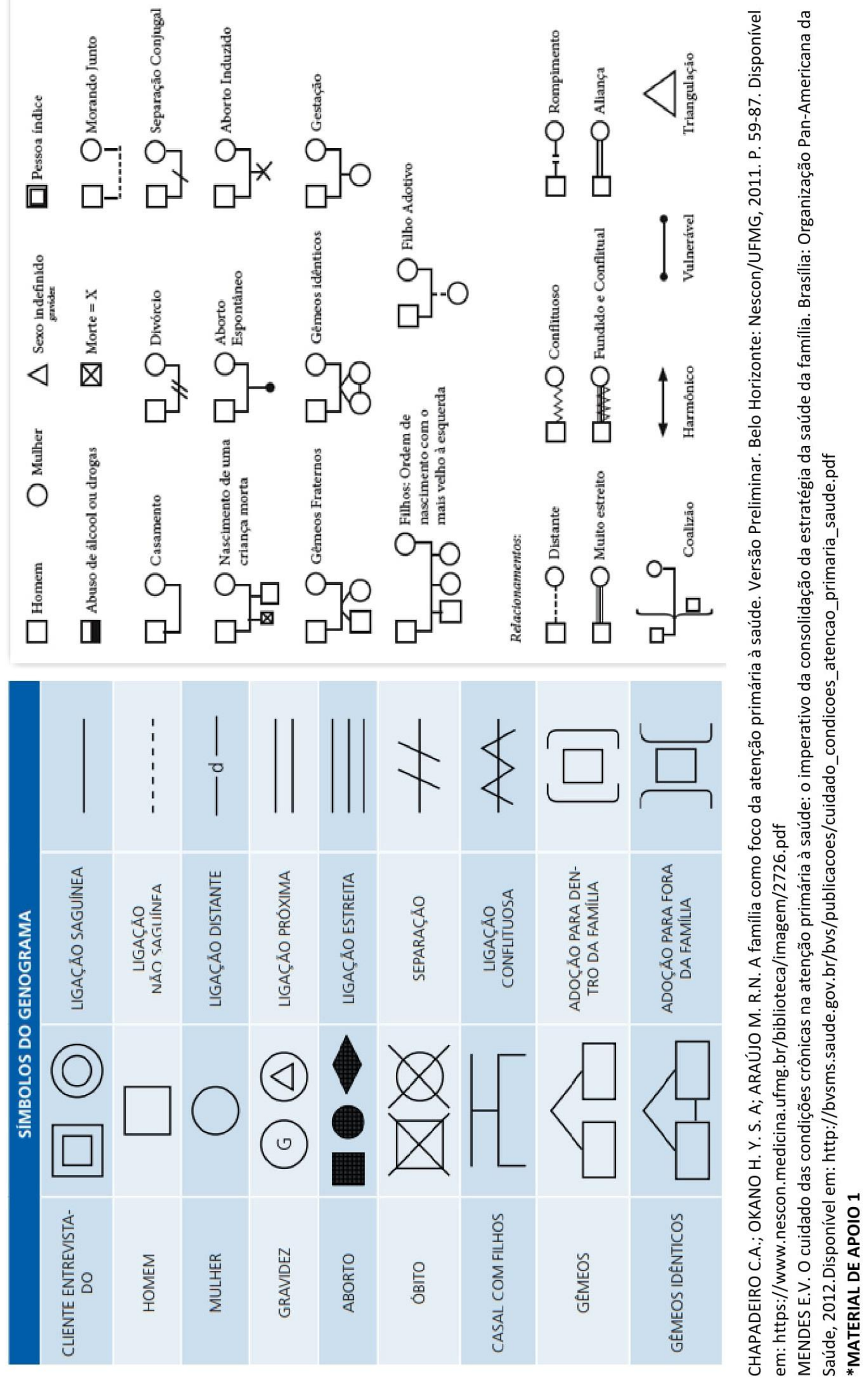


\section{APÊNDICE 8- QUADRO DE DISCURSOS CATEGORIZADOS}

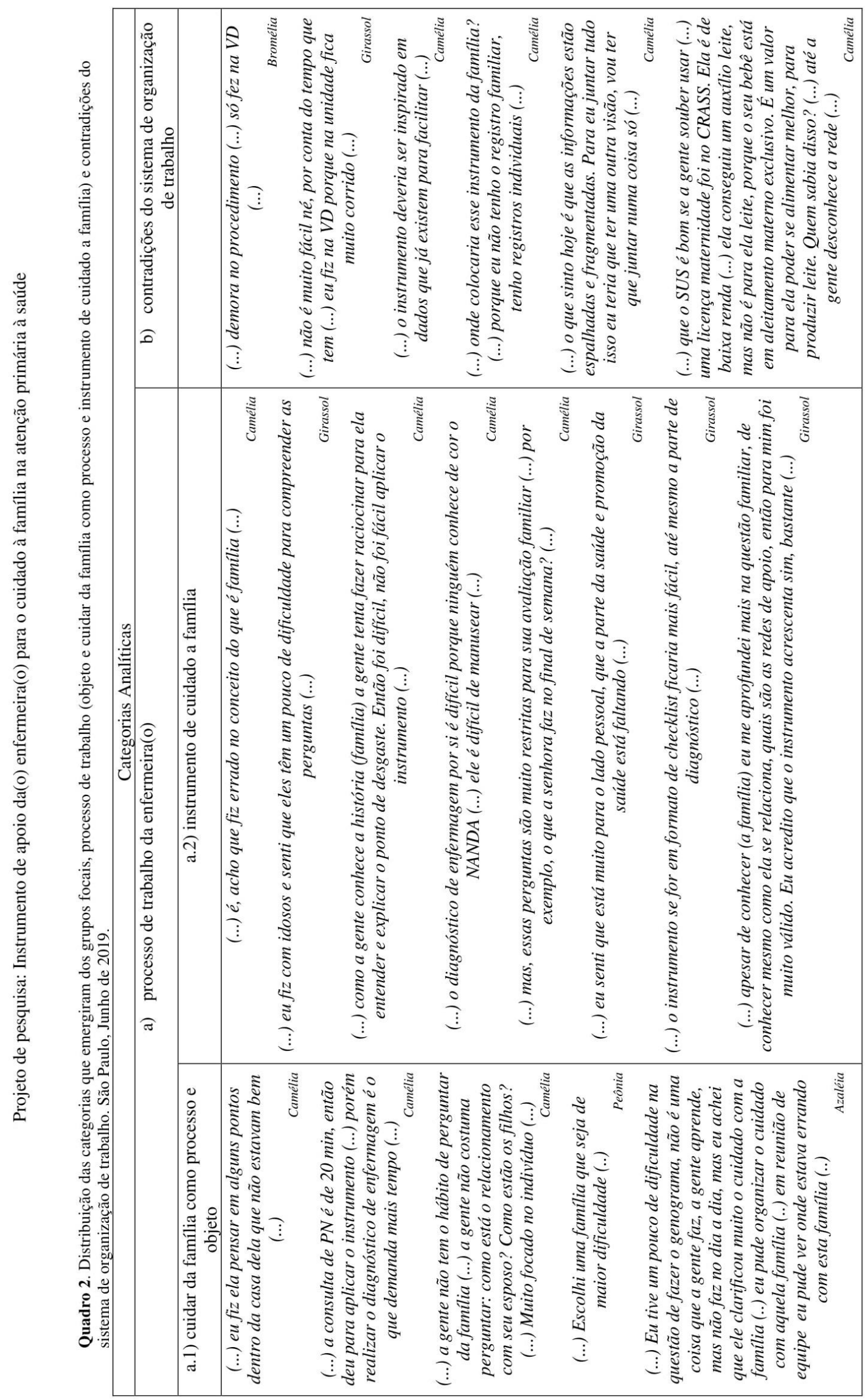




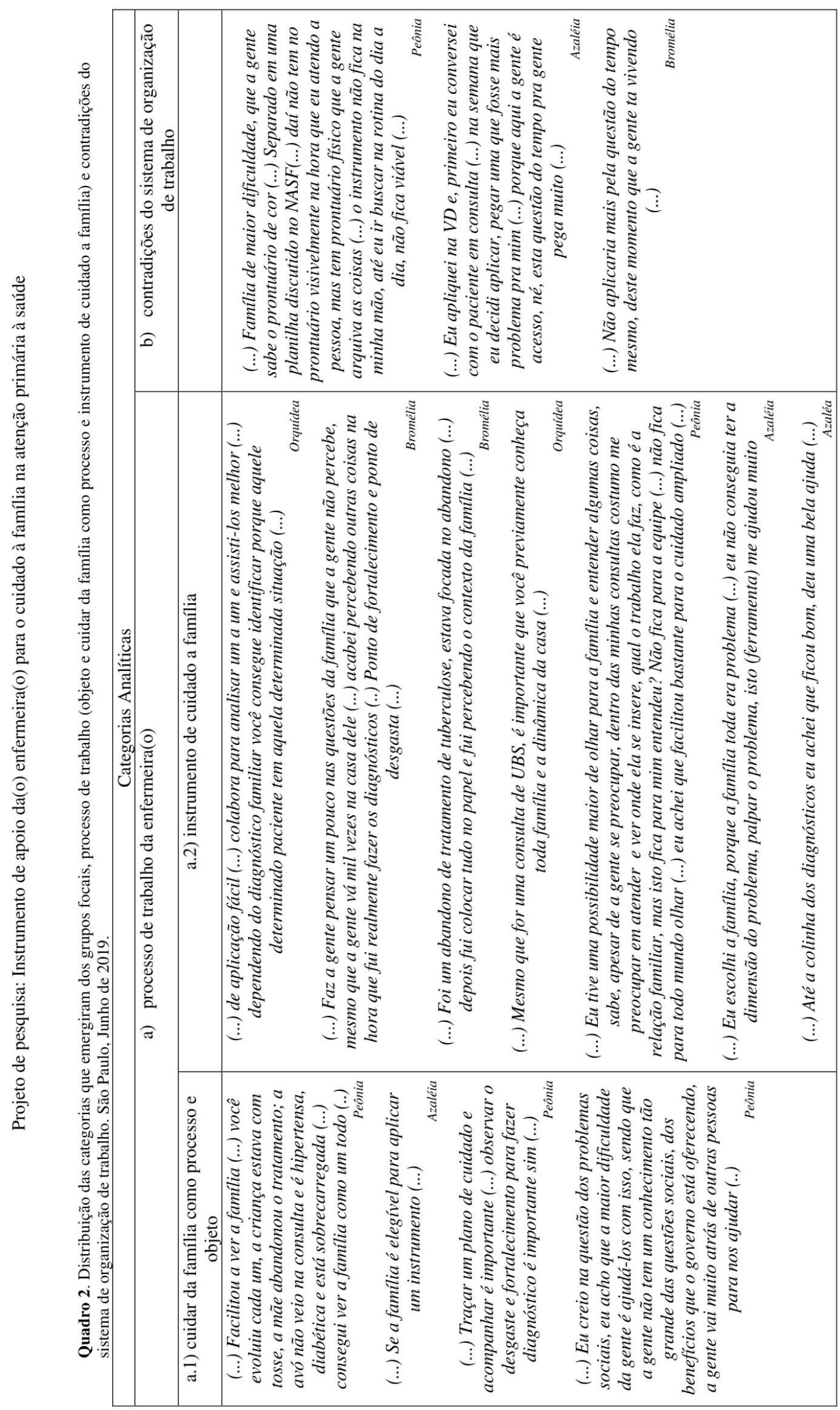




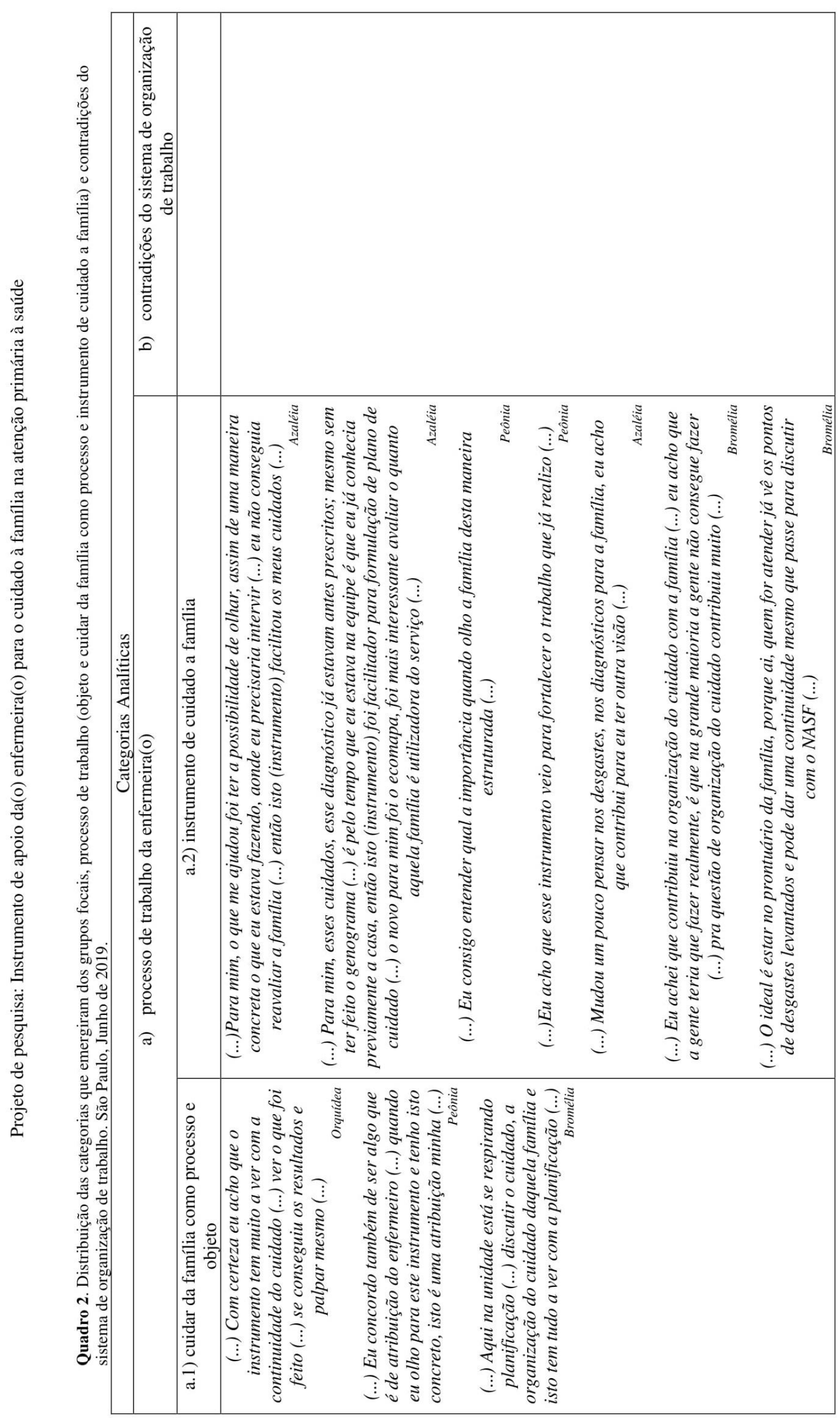


ANEXOS 


\title{
ANEXOS
}

\section{ANEXO 1 - EDITAL Nº10/2017 CAPES/COFEN}

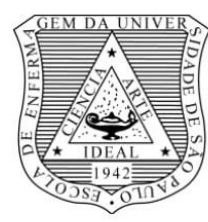

\author{
UNIVERSIDADE DE SÃO PAULO \\ ESCOLA DE ENFERMAGEM \\ Av. Dr. Enéas de Carvalho Aguiar, 419 - CEP 05403-000 - SP - SP \\ Tel. (11) 3061-7533 - E-mail: spgee@uspbr
}

Edital EE 우 10/2017

Abertura do Processo Seletivo para ingresso no Programa de Pós-Graduação Mestrado Profissional em Enfermagem na Atenção Primária em Saúde no SUS (Sistema Único de Saúde) 20 semestre de 2017

\section{Área de concentração: Cuidado em Atenção Primária em Saúde}

A Comissão Coordenadora do Programa de Pós-Graduação Mestrado Profissional em Enfermagem na Atenção Primária em Saúde no SUS, da Escola de Enfermagem (EE) da Universidade de São Paulo (USP), torna público aos interessados que, nos termos do Regimento de Pós-Graduação da USP e, conforme aprovação da Comissão de Pós-Graduação em 05 de abril de 2017, estarão abertas inscrições no período de 22 a 31 de maio de 2017 para o preenchimento de vagas destinadas ao Curso de Mestrado Profissional (MP) em Enfermagem na Atenção Primária em Saúde no Sistema Único de Saúde, área de concentração: Cuidado em Atenção Primária em Saúde, para início em agosto de 2017. O presente edital está vinculado ao projeto "Tecnologias para a Sistematização da Assistência de Enfermagem a Famílias na Atenção Básica”, contemplado com recursos do Edital no 27 - Acordo CAPES/COFEN.

\section{Apresentação:}

1.1. O Mestrado Profissional destina-se à qualificação continuada, em nível de pós-graduação stricto sensu, de enfermeiras(os), com experiência no âmbito da Atenção Primária em Saúde ou em serviços que apresentam interface com este nível de atenção. Em atendimento ao Edital no 27 - Acordo CAPES/COFEN, ao qual este edital está vinculado, as pesquisas científicas e tecnológicas, que serão desenvolvidas no referido Programa de Pós-Graduação, terão como foco a Sistematização da Assistência de Enfermagem às Famílias na Atenção Básica. Os formados no Programa terão a titulação de Mestre em Ciências.

1.2. Público-alvo: enfermeiras(os), com experiência no âmbito da Atenção Primária.

\section{Objetivos:}

2.1. Incrementar a qualificação para a prática profissional em saúde, baseada em referenciais teóricos e práticos e em evidências científicas que permitam a consolidação da clínica 


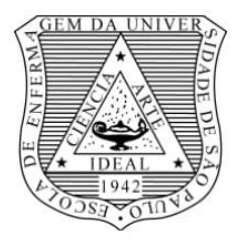

\section{UNIVERSIDADE DE SÃO PAULO ESCOLA DE ENFERMAGEM \\ Av. Dr. Enéas de Carvalho Aguiar, 419 - CEP 05403-000 - SP - SP Tel. (11) 3061-7533 - E-mail: spgee@uspbr}

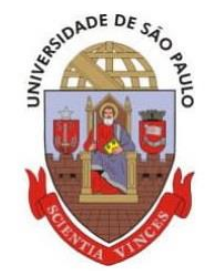

ampliada e a sistematização da assistência, tendo em vista os protocolos nacionais e regionais;

2.2. desenvolver competências para a intervenção nos âmbitos local e regional, na esfera do setor saúde, de forma articulada aos processos intersetoriais, que impactem nos determinantes e nos condicionantes do processo saúde-doença dos grupos populacionais;

2.3. estimular enfermeiras(os) a se tornarem investigadores das próprias práticas, por meio da apropriação de bases teóricas e metodológicas que possibilitem a avaliação crítica e continuada do trabalho;

2.4. realizar investigações científicas no cotidiano do trabalho em saúde, a partir dos problemas de saúde identificados e que possibilitem a proposição de novas tecnologias a serem aplicadas no aprimoramento da prática profissional, em convergência aos princípios e diretrizes do SUS e que impactem nos perfis epidemiológicos da sociedade brasileira.

\section{3. Área de Concentração}

Cuidado em Atenção Primária em Saúde

\section{Linhas de Pesquisa}

a) Processos de cuidado na Atenção Primária em Saúde: trata da análise do processo do cuidado em saúde e do aprimoramento das práticas de saúde. Inclui estudos sobre captação e interpretação das necessidades de saúde da população, assim como a proposição e implementação de intervenções orientadas ao aprimoramento dos perfis epidemiológicos. Integra a construção e a validação de marcadores e indicadores de saúde, de vulnerabilidades e de adesão às práticas de saúde. Inclui os saberes e habilidades da Bioética Deliberativa na Atenção Primária, a fim de identificar os problemas éticos e subsidiar o processo de tomada de decisão no cuidado em saúde.

b) Tecnologias inovadoras voltadas ao cuidado em Atenção Primária em Saúde: trata da proposição e implementação de tecnologias voltadas ao cuidado em Atenção Primária, incorporando tecnologias leves, leves-duras e duras. Articula-se à análise, gestão e avaliação das políticas públicas de saúde e seu impacto em relação às necessidades de saúde da população. 


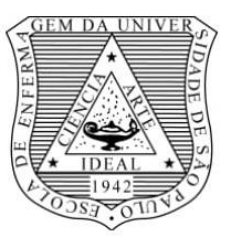

\section{UNIVERSIDADE DE SÃO PAULO ESCOLA DE ENFERMAGEM \\ Av. Dr. Enéas de Carvalho Aguiar, 419 - CEP 05403-000 - SP - SP Tel. (11) 3061-7533 - E-mail: spgee@uspbr}

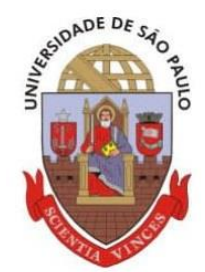

Integra estudos sobre conceitos e estratégias para a operacionalização e avaliação da Promoção da Saúde, no âmbito individual, coletivo e dos serviços de saúde.

\section{Quadro de Disciplinas}

1. ENS5914 Enfermagem em Saúde Coletiva na Atenção Primária

2. ENS5915 Políticas de Saúde e Atenção Primária

3. ENS5916 Bioética na Atenção Primária

4. ENS5917 Gestão do Cuidado na Atenção Primária e Interfaces com Outros Campos Disciplinares

5. ENS5918 Promoção da Saúde na Atenção Primária do SUS

6. ENS5919 Métodos de Pesquisa

7. ENS5920 Bioestatística

8. ENS5921 Tecnologias e Inovação nas Práticas de Cuidados em Atenção Primária de Saúde

9. ENS5922 Vigilância em Saúde na Atenção Primária

10.ENS5923 Doenças Infecciosas e Parasitárias na Atenção Primária em Saúde

11.ENS5963 Metodologias Qualitativas e Implementação de Evidências em Saúde Coletiva

\section{Orientadores}

1. Ana Luiza Vilela Borges (alvilela@usp.br)

2. Anna Luiza de Fátima Pinho Lins Gryschek (gryschek@usp.br)

3. Anna Maria Chiesa (amchiesa@usp.br)

4. Cássia Baldini Soares (cassiaso@usp.br)

5. Célia Maria Sivalli Campos (celiasiv@usp.br)

6. Elizabeth Fujimori (efujimor@usp.br)

7. Elma Lourdes Campos Pavone Zoboli (elma@usp.br)

8. Francisco Oscar de Siqueira França (fosfranca@usp.br)

9. Lislaine Aparecida Fracolll (lislaine@usp.br)

10. Lucia Yasuko Izumi Nichiata (izumi@usp.br)

11. Maria Clara Padoveze Fonseca Barbosa (padoveze@usp.br)

12. Maria Rita Bertolozzi (mrbertol@usp.br)

13. Renata Ferreira Takahashi (rftakaha@usp.br)

14. Rosa Maria Godoy Serpa da Fonseca (rmgsfon@usp.br) 


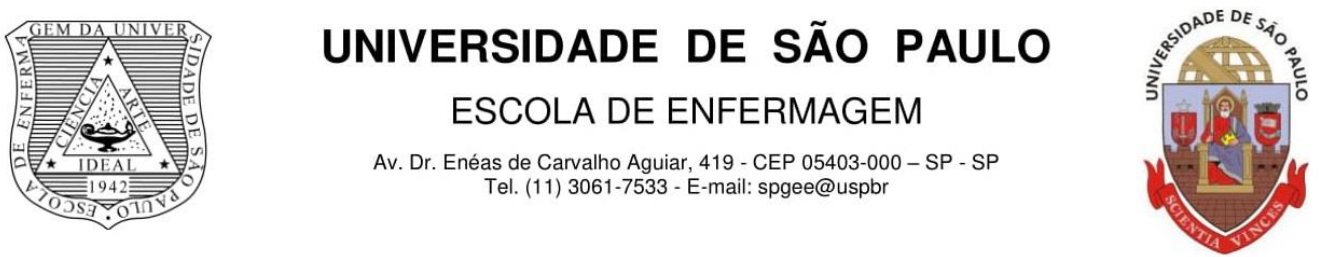

15. Sayuri Tanaka Maeda (sayuri@usp.br)

7. Os alunos selecionados poderão beneficiar-se de recursos financeiros destinados à aquisição de material de consumo para o desenvolvimento da pesquisa, ao pagamento de passagens e diárias para participação em eventos técnico-científicos e publicação de artigos para a divulgação dos produtos e resultados gerados no desenvolvimento do Programa, segundo planejamento e critérios definidos pela Comissão Coordenadora do Programa e disponibilidade orçamentária advinda do Edital CAPES/COREN.

\section{Vagas}

Serão oferecidas 10 vagas.

\section{Inscrições}

9.1. As inscrições serão realizadas no período de 22 a 31 de maio de 2017 . O candidato deverá preencher o requerimento de inscrição disponível, no site da Escola de Enfermagem da Universidade de São Paulo - www.ee.usp.br - e enviá-lo para o endereço de e-mail: ppg.mpaps.ee@usp.br, com o assunto “Requerimento de Inscrição”. Em seguida, o candidato deverá preencher o formulário para emissão do boleto bancário online, disponível no site da Escola de Enfermagem da Universidade de São Paulo e pagá-lo em qualquer agência bancária, até às 23 h59 do dia 31 de maio. O candidato deverá apresentar o comprovante de pagamento no dia da realização da prova escrita.

9.2. O valor da taxa de inscrição é de $\mathrm{R} \$ 150,00$ (cento e cinquenta reais).

Importante: as inscrições dos candidatos somente serão efetivadas após a conclusão do processo (envio do Requerimento de Inscrição por e-mail e o pagamento do boleto).

\section{Procedimentos de Seleção}

10.1. Primeira FASE - Eliminatória

a) Prova sobre capacidade de interpretação, argumentação, síntese e expressão escrita na temática de conhecimento do Programa. A prova será realizada no dia 05 de junho, às $\mathbf{9 h}$, na sala 23. na EEUSP. Não será permitida a entrada de candidatos após o horário inicial da prova. A 


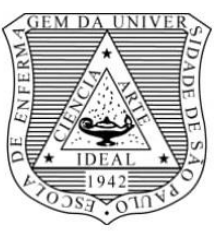

\section{UNIVERSIDADE DE SÃO PAULO ESCOLA DE ENFERMAGEM}

Av. Dr. Enéas de Carvalho Aguiar, 419 - CEP 05403-000 - SP - SP Tel. (11) 3061-7533 - E-mail: spgee@uspbr

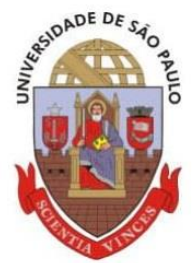

bibliografia recomendada será disponibilizada, a partir de 13 de abril de 2017, no site da EEUSP, na página do Programa (http://www.ee.usp.br/site/Index.php//paginas/mostrar/1564/2225/153).

b) Na data da prova o candidato deverá entregar, na Secretaria do Serviço de Pós-Graduação, localizada no 3 o andar da EEUSP, sala 301, das $9 \mathrm{~h}$ às $17 \mathrm{~h}$, o anteprojeto do estudo a ser desenvolvido no Mestrado Profissional contendo: título do projeto, nome do candidato, descrição do problema, justificativa, objetivos, metodologia e referências consultadas. Entregar o projeto impresso, digitado em Word Fonte Times New Roman, tamanho 12, espaço 1,5, com no mínimo dez páginas.

c) O resultado da prova será divulgado no dia 09 (nove) de junho de 2017, no site da EEUSP e no mural do Serviço de Pós-Graduação, 3a andar da EEUSP, Pós-Graduação. Nota mínima para aprovação: 7,0 (sete).

\subsection{SEgunda FASE - ClAssificatóRIA}

Os candidatos habilitados na primeira fase deverão entregar na Secretaria do Serviço de PósGraduação, no período de 12 (doze) a 14(quatorze) de junho de 2017, pessoalmente ou por procuração simples com firma reconhecida:

a) uma cópia dos seguintes documentos:

- Curriculum vitae, conforme modelo do Currículo Lattes (http://lattes.cnpq.br), com cópia dos documentos comprobatórios.

- documento de identidade: RG ou RNE.

- comprovante de conclusão do Curso de Graduação em Instituição de Ensino Superior devidamente reconhecida. Não serão aceitos comprovantes de conclusão em "licenciaturas curtas".

- histórico Escolar completo do Curso de Graduação.

b) Carta de apresentação pessoal, contendo: dados pessoais, profissionais, expectativas e razões da inscrição no processo seletivo para a realização do Mestrado Profissional em enfermagem na Atenção Primária em Saúde no SUS, da EEUSP.

c) Comprovante de aprovação no exame de proficiência em língua Inglesa, conforme disposto no item 11 (onze), que deverá ser entregue no dia da arguição oral. 


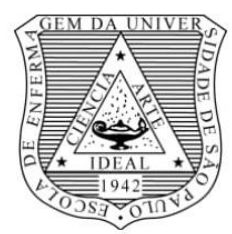

\section{UNIVERSIDADE DE SÃO PAULO ESCOLA DE ENFERMAGEM \\ Av. Dr. Enéas de Carvalho Aguiar, 419 - CEP 05403-000 - SP - SP Tel. (11) 3061-7533 - E-mail: spgee@uspbr}

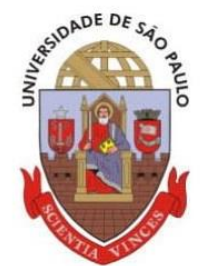

d) Agendar a arguição oral no Serviço de Pós-Graduação. A arguição poderá ser realizada presencialmente ou, nos casos de candidatos que estejam em outro estado, por meio de Skype, em horários a serem definidos compreendidos entre os dias 19 (dezenove) e 23 (vinte e três) de junho.

- O candidato que optar por realizar a arguição por meio de Skype deverá:

1. Fornecer seu contato de Skype no ato da inscrição.

2. Providenciar o equipamento técnico necessário para a sua conexão.

a. O candidato que optar pela arguição por meio de Skype será o responsável pelo estabelecimento de sua conexão. Eventuais problemas com sua conexão serão de responsabilidade do candidato e não haverá remarcação da arguição. Arguição por meio de Skype sem vídeo não será realizada.

3. Conectar-se ao Skype, utilizando o contato fornecido no ato da inscrição, no dia e horário agendados previamente.

\section{Serão critérios de avaliação:}

$\mathrm{Na}$ análise do curriculum vitae: experiência profissional e formação acadêmica compatível com a proposta do Mestrado Profissional. Nota mínima para aprovação: 7,0 (sete).

Na arguição: consistência de argumentação e coerência de ideias desenvolvidas no anteprojeto de estudo, justificativa do interesse e disponibilidade para cursar a pós-graduação. Nota mínima para aprovação: 7,0 (sete).

\section{Proficiência em língua estrangeira}

1. A proficiência em língua inglesa será comprovada por atestado de aprovação do exame, com validade de dois anos, a partir da data de sua realização, nas seguintes Instituições:

a) União Cultural Brasil-Estados Unidos: a porcentagem mínima de acerto exigida para o Mestrado Profissional é $50 \%$.

b) Centro de Línguas da Faculdade de Filosofia, Letras e Ciências Humanas da USP: o resultado exigido para o Mestrado Profissional é "Suficiente".

c) Cultura Inglesa: a porcentagem mínima de acerto exigida para o Mestrado Profissional é 50\%. 


\section{UNIVERSIDADE DE SÃO PAULO ESCOLA DE ENFERMAGEM \\ Av. Dr. Enéas de Carvalho Aguiar, 419 - CEP 05403-000 - SP - SP Tel. (11) 3061-7533 - E-mail: spgee@uspbr}

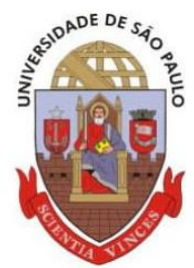

d) Educational Testing Service, que aplica o TOEFL ${ }^{\circledR}$ - Test of English as Foreign Language ${ }^{\mathrm{TM}}$, Internet Based Test - IBT (eletrônico): será aprovado para o Mestrado, o candidato que obtiver o mínimo de 60 (sessenta) pontos.

e) International English Language Test (IELTS): será aprovado para o Mestrado, o candidato que obtiver o mínimo de 60 (sessenta) pontos.

2. Aos estudantes estrangeiros, além da proficiência em língua inglesa, será exigida a proficiência em língua portuguesa, demonstrada por meio da apresentação do Certificado de Proficiência em Língua Portuguesa para Estrangeiros, CELPE BRAS, nível intermediário, em até 13 (treze) meses para o curso de Mestrado, contados a partir do início de contagem de prazo do aluno no curso.

\section{Resultado Final}

A nota final será a média aritmética das provas, sendo aprovados os candidatos que obtiverem nota final igual ou superior a 7,0 .

O resultado final será divulgado em 30 (trinta) de junho de 2017, no quadro informativo do Serviço de Pós-Graduação e no site da EEUSP ( informado por telefone.

\section{Matrícula}

A matrícula deverá ser efetuada pessoalmente ou por procuração simples com firma reconhecida, no Serviço de Pós-Graduação, 3o andar da EE, sala 301, das 9 h00 às 17h00, no período de 03 (três) a 07 (sete) de julho de 2017.

A matrícula de candidato estrangeiro deverá ser efetuada pessoalmente, e somente poderá ser admitido e mantido no Curso, o aluno que apresentar documento de identidade válido e visto temporário ou permanente com autorização para estudar no Brasil.

No ato da matrícula, o aluno deverá entregar:

1. Requerimento de matrícula preenchido, disponível no site da EEUSP, assinado pelo aluno e pelo orientador.

2. Cópias simples, acompanhadas do original, dos seguintes documentos:

a) Cédula de identidade (RG) ou Registro Nacional para Estrangeiros (RNE) 


\section{UNIVERSIDADE DE SÃO PAULO ESCOLA DE ENFERMAGEM}

Av. Dr. Enéas de Carvalho Aguiar, 419 - CEP 05403-000 - SP - SP Tel. (11) 3061-7533 - E-mail: spgee@uspbr

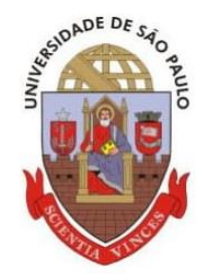

b) Cadastro de Pessoa Física (CPF)

c) Certidão de nascimento ou casamento

d) Prova de quitação com o serviço militar, somente para brasileiros natos ou naturalizados do sexo masculino

e) Título de Eleitor, somente para brasileiros natos ou naturalizados

f) Diploma(s) e Histórico(s) Escolar(es) dos Cursos de Graduação e Licenciatura Plena (este último, se pertinente), obtido em Curso oficialmente reconhecido e devidamente registrado

3. Plano de Estudos, disponível no site da EEUSP, assinado pelo orientador e aluno.

4. Carta da Instituição de origem, permitindo o afastamento total ou parcial do candidato para realizar o Curso de Pós-Graduação, quando o candidato estiver vinculado a alguma Instituição ou serviço.

\section{Disposições Finais}

14.1 A Comissão Coordenadora do Mestrado Profissional não se obriga a preencher a totalidade ofertada das vagas.

14.2 Não serão aceitos pedidos de revisão de prova.

14.3 Nenhum resultado será fornecido por telefone.

14.4 Os candidatos (selecionados ou não selecionados) deverão retirar a documentação até 30 dias após a divulgação do resultado do processo seletivo, no Serviço de Pós-Graduação. Após esta data, a documentação será eliminada.

14.5 A Comissão Coordenadora do Programa encaminhará o resultado final do Processo Seletivo à Comissão de Pós-Graduação da EEUSP para homologação.

14.6 É de inteira responsabilidade do candidato, o atendimento dos requisitos constantes neste edital e a veracidade das informações prestadas para o processo seletivo.

14.7 Os casos omissos neste Edital serão resolvidos pela Comissão Coordenadora do Programa de Mestrado Profissional.

Comissão de Pós-Graduação, 05 de abril de 2017.

Divulgue-se. 


\section{ANEXO 2 - CARTA DE APROVAÇÃO DO CEP/USP}

USP - ESCOLA DE
ENFERMAGEM DA
UNIVERSIDADE DE SÃO $\begin{aligned} & \text { Platoformo } \\ & \text { Brasil }\end{aligned}$

\section{PARECER CONSUBSTANCIADO DO CEP}

\section{DADOS DO PROJETO DE PESQUISA}

Título da Pesquisa: Instrumento para a abordagem familiar na Estratégia Saúde da Família: potencialidades para o cuidado do enfermeiro.

Pesquisador: ALESSANDRA CRISTINA FERREIRA MARTINS

Área Temática:

Versão: 5

CAAE: 91719218.8 .0000 .5392

Instituição Proponente: Escola de Enfermagem da Universidade de São Paulo - EEUSP

Patrocinador Principal: Financiamento Próprio

\section{DADOS DO PARECER}

\section{Número do Parecer: 3.031 .223}

\section{Apresentação do Projeto:}

Trata-se de um estudo descritivo, de abordagem qualitativa com estruturação metodológica da pesquisa ação.

O presente projeto propõe testar o "Instrumento de Apoio para elaboração do Projeto de cuidado à família" que foi elaborado na disciplina de Atenção Básica da Escola de

Enfermagem da Universidade de São Paulo, pela equipe de enfermagem no contexto da Estratégia de Saúde da Família, com a finalidade de verificar as potências e limites deste instrumento para a sistematização do cuidado do enfermeiro para famílias na Estratégia Saúde da Família.

O projeto será desenvolvido com profissionais que atuam nas unidades que fazem parte da Coordenadoria de Saúde Sul. Serão elencados dois enfermeiros por unidade, que tenham pelo menos 5 anos de atuação no serviço, totalizando assim, 26 enfermeiros.

Estes profissionais serão responsáveis pela aplicação do "Instrumento de Apoio para elaboração do Projeto de cuidado à família" proposto neste projeto. Cada enfermeiro irá aplicar o questionário em 2 famílias durante o período de visita domiciliar.

O estudo será desenvolvido em 3 etapas:

Etapa 1 - Realização de oficina junto aos profissionais envolvidos;

Etapa 2 - Aplicação e análise do instrumento pelos profissionais;

Etapa 3 - Oficina de feedback

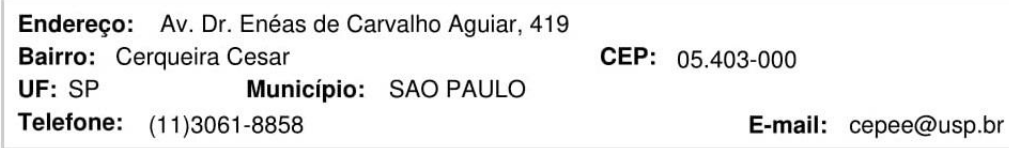




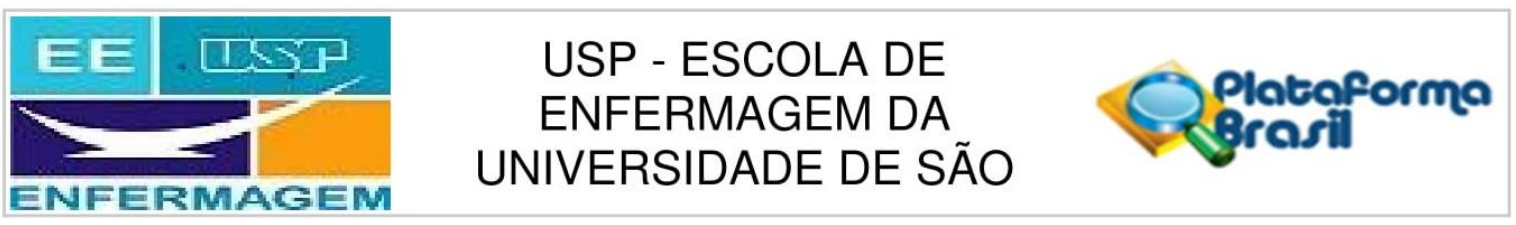

Continuação do Parecer: 3.031 .223

Como ferramenta de análise será utilizada o método de análise de conteúdo.

\section{Objetivo da Pesquisa:}

O objetivo geral da pesquisa é demonstrar as potencialidades e limites do "Instrumento de Apoio para elaboração do Projeto de cuidado à família" para a sistematização da assistência de enfermagem à família na ESF (Estratégia Saúde da Família).

Objetivos Específicos

- Caracterizar as concepções dos enfermeiros sobre família, necessidades de saúde e a articulação das mesmas com a Sistematização da Assistência de Enfermagem à família.

- Testar o "Instrumento de Apoio para elaboração do Projeto de cuidado à família" a uma família e sistematizar seus resultados.

- Identificar as percepções dos enfermeiros sobre o "Instrumento de Apoio para elaboração do Projeto de cuidado à família "como recurso para sistematizar cuidado de enfermagem a famílias na ESF.

- Descrever as potencialidades e limites do "Instrumento de Apoio para elaboração do Projeto de cuidado à família" para a SAE à família na ESF.

\section{Avaliação dos Riscos e Benefícios:}

A pesquisadora coloca que os riscos da pesquisa estão relacionados a possíveis alterações na rotina do trabalho para a aplicação do instrumento proposto. O risco para as famílias participantes é um possível constrangimento ao responder alguma questão. A pesquisadora deixa claro que o participante pode deixar de responder, caso deseje.

Como benefício, o projeto prevê a qualificação do cuidado para as famílias que são atendidas pela Estratégia Saúde da Família.

\section{Comentários e Considerações sobre a Pesquisa:}

Pesquisa de interesse para a área.

Orçamento de $\mathrm{R} \$ 900,00$, que será custeado pela pesquisadora.

\section{Considerações sobre os Termos de apresentação obrigatória:}

A pesquisadora realizou as correções e modificações solicitadas, incluindo o grupo de pesquisa relativo aos participantes e incluiu o risco para esse grupo nos documentos apropriados.

Endereço: Av. Dr. Enéas de Carvalho Aguiar, 419

Bairro: Cerqueira Cesar

UF: SP Município: SAO PAULO

Telefone: (11)3061-8858

CEP: $05.403-000$

E-mail: cepee@usp.br 


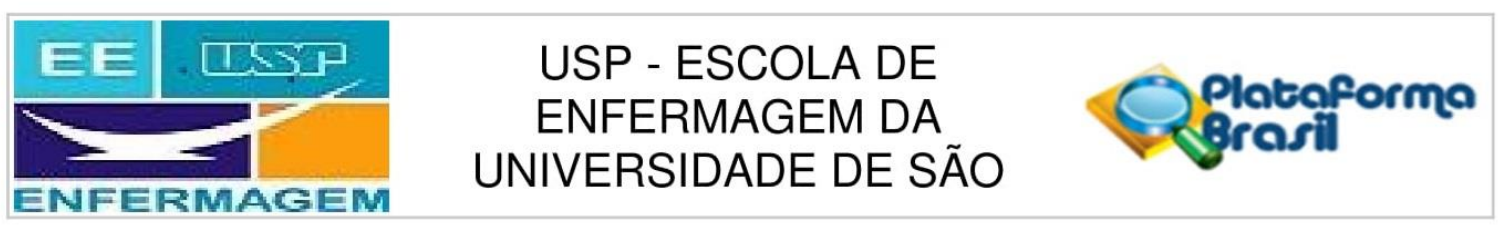

Continuação do Parecer: 3.031 .223

\section{Recomendações:}

Não há.

Conclusões ou Pendências e Lista de Inadequações:

Não há pendências.

\section{Considerações Finais a critério do CEP:}

Este CEP informa a necessidade de registro dos resultados parciais e finais na Plataforma Brasil. Esta aprovação não substitui a autorização da instituição coparticipante, antes do início da coleta de dados.

Este parecer foi elaborado baseado nos documentos abaixo relacionados:

\begin{tabular}{|c|c|c|c|c|}
\hline Tipo Documento & Arquivo & Postagem & Autor & Situação \\
\hline $\begin{array}{l}\text { Informações Básicas } \\
\text { do Projeto }\end{array}$ & $\begin{array}{l}\text { PB_INFORMAÇÖES_BÁSICAS_DO_P } \\
\text { ROJETO 1133165.pdf }\end{array}$ & $\begin{array}{l}29 / 10 / 2018 \\
17: 27: 36\end{array}$ & & Aceito \\
\hline $\begin{array}{l}\text { Projeto Detalhado / } \\
\text { Brochura } \\
\text { Investigador }\end{array}$ & Projeto_Detalhado.pdf & $\begin{array}{c}29 / 10 / 2018 \\
17: 26: 12\end{array}$ & $\begin{array}{l}\text { ALESSANDRA } \\
\text { CRISTINA } \\
\text { FERREIRA } \\
\end{array}$ & Aceito \\
\hline $\begin{array}{l}\text { TCLE / Termos de } \\
\text { Assentimento / } \\
\text { Justificativa de } \\
\text { Ausência }\end{array}$ & Novos_TCLE.pdf & $\begin{array}{l}29 / 10 / 2018 \\
17: 25: 56\end{array}$ & $\begin{array}{l}\text { ALESSANDRA } \\
\text { CRISTINA } \\
\text { FERREIRA } \\
\text { MARTINS } \\
\end{array}$ & Aceito \\
\hline Folha de Rosto & folhaderostonova.pdf & $\begin{array}{l}20 / 09 / 2018 \\
11: 48: 26\end{array}$ & $\begin{array}{l}\text { ALESSANDRA } \\
\text { CRISTINA } \\
\text { FERREIRA } \\
\end{array}$ & Aceito \\
\hline
\end{tabular}

\section{Situação do Parecer:}

Aprovado

Necessita Apreciação da CONEP:

Não

SAO PAULO, 21 de Novembro de 2018

Assinado por:

Márcia Aparecida Ferreira de Oliveira

(Coordenador(a))

Endereço: Av. Dr. Enéas de Carvalho Aguiar, 419

Bairro: Cerqueira Cesar

CEP: $05.403-000$

UF: SP

Município: SAO PAULO

Telefone: (11)3061-8858

E-mail: cepee@usp.br 


\section{ANEXO 3 - CARTA DE APROVAÇÃO DO CEP/SMS}

SECRETARIA MUNICIPAL DA
SAÚDE DE SÃO PAULO -
SMS/SP

\section{PARECER CONSUBSTANCIADO DO CEP}

\section{Elaborado pela Instituição Coparticipante}

\section{DADOS DO PROJETO DE PESQUISA}

Título da Pesquisa: Instrumento para a abordagem familiar na Estratégia Saúde da Família: potencialidades para o cuidado do enfermeiro.

Pesquisador: ALESSANDRA CRISTINA FERREIRA MARTINS

Área Temática:

Versão: 3

CAAE: 91719218.8 .3001 .0086

Instituição Proponente: COORDENADORIA REGIONAL DE SAÚDE SUL

Patrocinador Principal: Financiamento Próprio

\section{DADOS DO PARECER}

Número do Parecer: 3.107 .525

Apresentação do Projeto:

Trata-se de um estudo descritivo, de abordagem qualitativa com estruturação metodológica da pesquisaação.

O estudo foi proposto pela EEUSP, porém não fica claro o nível de formação/especialização.

Devido à complexidade do contexto familiar, suas diferenças e ambivalências, há uma necessidade de ampliação na abordagem para com as famílias no território de atuação das Equipes de Estratégia Saúde da Família (eESF). Segundo levantamento de informações realizado pelos pesquisadores, ainda hoje, há uma lacuna de instrumentos para a sistematização do cuidado à família pela ESF. As ações ainda são individualizadas, porém, é preciso identificar as necessidades da família, levando em consideração seus simbolismos, organização, dinâmica, inserção social e demais especificidades.

A disciplina de AB (Atenção Básica) da EEUSP (Escola de Enfermagem da Universidade de São Paulo) formulou um instrumento pedagógico de sistematização do cuidado de enfermagem a família , que vem sendo utilizado junto aos estudantes de graduação e precisa ser aplicado aos profissionais enfermeiros testar suas potencialidades e seus limites.

Deste modo, as perguntas de pesquisa deste projeto são: O Instrumento de Sistematização da Assistência formulado na disciplina de $A B$ (Atenção Básica) é potente para auxiliar os profissionais de enfermagem da ESF na organização do cuidado a família? Esse instrumento de sistematização permite a construção de um PTS e tem potencia para ser utilizado como uma SAE para a familia? O

Endereço: Rua General Jardim, 36 - 8adar Bairro: Vila Buarque

UF: SP Município: SAO PAULO

Telefone: (11)3397-2464

CEP: $\quad 01.223-010$

E-mail: smscep@gmail.com 


\section{SECRETARIA MUNICIPAL DA
SAÚDE DE SÃO PAULO -
SMS/SP}

Continuação do Parecer: 3.107 .525

presente projeto propõe, então, a testar o "Instrumento de Apoio para elaboração do Projeto de cuidado á família", pela equipe de enfermagem no contexto da SF, com a finalidade de verificar as potências e limites deste instrumento para a sistematização do cuidado do enfermeiro para famílias na Estratégia Saúde da Família.

A pesquisa será realizada no âmbito da Coordenadoria de Saúde Sul, nas unidades de ESF geridas pela Sociedade Beneficente Israelita Brasileira Albert Einstein, nas regiões de Campo Limpo e Vila Andrade. A amostra será composta por enfermeiros que atuam nessas unidades, por serem profissionais diretamente implicados com o objeto do projeto. Serão elencados dois enfermeiros por unidade, que tenham pelo menos 5 anos de atuação no serviço, totalizando assim, 26 enfermeiros.

O estudo será desenvolvido em 3 etapas:

Etapa 1 - Realização de oficina junto aos profissionais envolvidos;

Etapa 2 - Aplicação e análise do instrumento pelos profissionais (aplicação em 26 famílias assistidas pelo enfermeiro na respectiva UBS); Posterior análise do conteúdo pelas pesquisadoras. Etapa 3 - Oficina de feedback a fim de concluir suas limitações e potencialidades(a efetividade e a validação do instrumento não serão realizadas neste estudo).

Cada enfermeiro será responsável pela aplicação do "Instrumento de Apoio para elaboração do Projeto de cuidado à família" proposto neste projeto em duas famílias do seu território, escolhidas aleatoriamente. $\mathrm{O}$ conteúdo registrado pelos enfermeiros acerca do instrumento proposto será analisado pelas pesquisadoras, com o objetivo de adaptar o "Instrumento de Apoio para elaboração do Projeto de cuidado à família" às reais necessidades da prática da equipe de enfermagem para qualificar o cuidado à essas famílias.

A análise será feita por metodologia qualitativa, usando o método de análise de conteúdo.

\section{Objetivo da Pesquisa:}

Objetivo Primário: Demonstrar as potencialidades e limites do "Instrumento de Apoio para elaboração do Projeto de cuidado à família" para a sistematização da assistência de enfermagem à família na ESF.

Objetivo Secundários:

- Caracterizar as concepções dos enfermeiros sobre família, necessidades de saúde e a articulação das mesmas com a Sistematização da daAssistência de Enfermagem à família.

- Testar o "Instrumento de Apoio para elaboração do Projeto de cuidado à família" a uma família e sistematizar seus resultados. Identificar as percepções dos enfermeiros sobre o "Instrumento de Apoio para elaboração do Projeto de cuidado à família "como recurso para sistematizar cuidado de

Endereço: Rua General Jardim, 36 - 8andar

Bairro: Vila Buarque

UF: SP Município: SAO PAULO

Telefone: (11)3397-2464

CEP: $01.223-010$ 


\section{- Ocomité de SECRETARIA MUNICIPAL DA SAÚDE DE SÃO PAULO - SMS/SP

Continuação do Parecer: 3.107 .525

enfermagem a famílias na ESF.

- Descrever as potencialidades e limites do "Instrumento de Apoio para elaboração do Projeto de cuidado à família" para a SAE à família na ESF.

\section{Avaliação dos Riscos e Benefícios:}

Foram adequadamente analisados riscos e benefícios da pesquisa.

\section{Comentários e Considerações sobre a Pesquisa:}

A metodologia descrita está adequada aos objetivos propostos.

\section{Considerações sobre os Termos de apresentação obrigatória:}

A Folha de Rosto está corretamente preenchida, foram identificadas instituição proponente e coparticipante, autorização para realização da pesquisa foi adequadamente apresentada.

TCLE, Cronograma, orçamento detalhado e fonte financiadora estão adequados.

\section{Conclusões ou Pendências e Lista de Inadequações:}

Não há.

As pendência foram respondidas de forma satisfatória pela pesquisadora.

\section{Considerações Finais a critério do CEP:}

Para início da coleta dos dados, o pesquisador deverá se apresentar na mesma instância que autorizou a realização do estudo (Coordenadoria, Supervisão, SMS/Gab, etc).

Salientamos que o pesquisador deve desenvolver a pesquisa conforme delineada no protocolo aprovado. Eventuais modificações ou emendas ao protocolo devem ser apresentadas ao CEP de forma clara e sucinta, identificando a parte do protocolo a ser modificada e suas justificativas. Lembramos que esta modificação necessitará de aprovação ética do CEP antes de ser implementada.

De acordo com a Res. CNS 466/12, o pesquisador deve apresentar os relatórios parciais e final através da Plataforma Brasil, ícone Notificação. Uma cópia digital (CD/DVD) do projeto finalizado deverá ser enviada à instância que autorizou a realização do estudo, via correio ou entregue pessoalmente, logo que o mesmo estiver concluído.

Este parecer foi elaborado baseado nos documentos abaixo relacionados:

\begin{tabular}{|l|l|c|c|c|}
\hline \multicolumn{1}{|c|}{ Tipo Documento } & \multicolumn{1}{|c|}{ Arquivo } & Postagem & Autor & Situação \\
\hline Informações Básicas & PB_INFORMAÇÕES_BÁSICAS_DO_P & $04 / 01 / 2019$ & & Aceito \\
do Projeto & ROJETO 1262215.pdf & $10: 46: 42$ & & \\
\hline
\end{tabular}

Endereço: Rua General Jardim, 36 - 8a andar Bairro: Vila Buarque

UF: SP Município: SAO PAULO

Telefone: (11)3397-2464

CEP: $01.223-010$ E-mail: smscep@gmail.com 


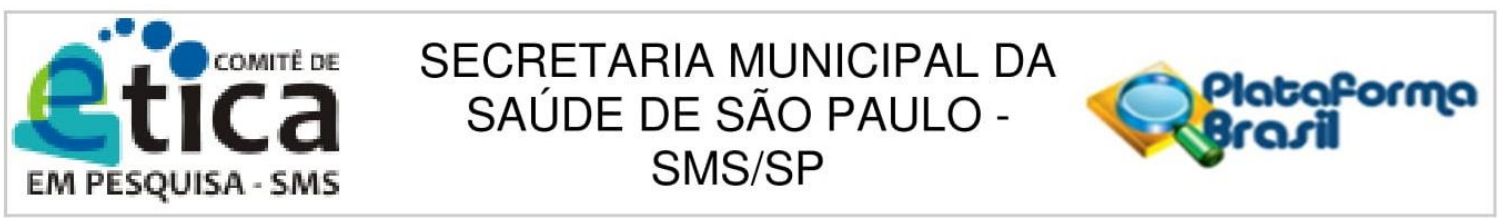

Continuação do Parecer: 3.107.525

\begin{tabular}{|c|c|c|c|c|}
\hline Outros & Respostas_CEPSMS.docx & $\begin{array}{c}04 / 01 / 2019 \\
10: 44: 42\end{array}$ & $\begin{array}{l}\text { ALESSANDRA } \\
\text { CRISTINA } \\
\text { FERREIRA }\end{array}$ & Aceito \\
\hline $\begin{array}{l}\text { TCLE / Termos de } \\
\text { Assentimento / } \\
\text { Justificativa de } \\
\text { Ausência }\end{array}$ & TCLE_FAMILIA.docx & $\begin{array}{c}14 / 12 / 2018 \\
10: 55: 10\end{array}$ & $\begin{array}{l}\text { ALESSANDRA } \\
\text { CRISTINA } \\
\text { FERREIRA } \\
\text { MARTINS }\end{array}$ & Aceito \\
\hline $\begin{array}{l}\text { Projeto Detalhado / } \\
\text { Brochura } \\
\text { Investigador }\end{array}$ & Projeto.docx & $\begin{array}{c}14 / 12 / 2018 \\
10: 52: 17\end{array}$ & $\begin{array}{l}\text { ALESSANDRA } \\
\text { CRISTINA } \\
\text { FERREIRA }\end{array}$ & Aceito \\
\hline $\begin{array}{l}\text { TCLE / Termos de } \\
\text { Assentimento / } \\
\text { Justificativa de } \\
\text { Ausência }\end{array}$ & TCLE_ENFERMEIRO.docx & $\begin{array}{c}14 / 12 / 2018 \\
10: 44: 02\end{array}$ & $\begin{array}{l}\text { ALESSANDRA } \\
\text { CRISTINA } \\
\text { FERREIRA } \\
\text { MARTINS }\end{array}$ & Aceito \\
\hline Parecer Anterior & Parecer.pdf & $\begin{array}{c}14 / 12 / 2018 \\
10: 43: 12\end{array}$ & $\begin{array}{l}\text { ALESSANDRA } \\
\text { CRISTINA } \\
\text { FERREIRA }\end{array}$ & Aceito \\
\hline $\begin{array}{l}\text { Projeto Detalhado / } \\
\text { Brochura } \\
\text { Investigador }\end{array}$ & Projeto_Detalhado.pdf & $\begin{array}{c}29 / 10 / 2018 \\
17: 26: 12\end{array}$ & $\begin{array}{l}\text { ALESSANDRA } \\
\text { CRISTINA } \\
\text { FERREIRA } \\
\end{array}$ & Aceito \\
\hline $\begin{array}{l}\text { TCLE / Termos de } \\
\text { Assentimento / } \\
\text { Justificativa de } \\
\text { Ausência } \\
\end{array}$ & Novos_TCLE.pdf & $\begin{array}{c}29 / 10 / 2018 \\
17: 25: 56\end{array}$ & $\begin{array}{l}\text { ALESSANDRA } \\
\text { CRISTINA } \\
\text { FERREIRA } \\
\text { MARTINS } \\
\end{array}$ & Aceito \\
\hline
\end{tabular}

\section{Situação do Parecer:}

Aprovado

Necessita Apreciação da CONEP:

Não

SAO PAULO, 07 de Janeiro de 2019

Assinado por:

SIMONE MONGELLI DE FANTINI

(Coordenador(a))

Endereço: Rua General Jardim, 36 - 8ํandar

Bairro: Vila Buarque

UF: SP

Município: SAO PAULO

Telefone: (11)3397-2464
CEP: $01.223-010$

E-mail: smscep@gmail.com 


\section{ANEXO 4 - INSTRUMENTO ORIGINAL DA EEUSP \\ Instrumento de Apoio para Elaboração do Plano de Cuidado à Família}

Data da entrevista:

Nomes dos entrevistadores:

Nome(s) do(s) entrevistado(s):

Prontuário da família: Equipe:

\section{Dados gerais sobre a composição familiar}

Quem são considerados os responsáveis pela família:

Quantas pessoas moram na residência:

Quem são as pessoas que moram na residência:

\begin{tabular}{|l|l|l|l|l|}
\hline $\mathrm{N}^{\mathrm{o}}$ & Nome & Idade & $\begin{array}{c}\text { Relação com os } \\
\text { responsáveis }\end{array}$ & $\begin{array}{c}\text { Atividade (trabalho } \\
\text { remunerado/estuda/dona de } \\
\text { casa) }\end{array}$ \\
\hline 1 & & & & \\
\hline 2 & & & & \\
\hline 4 & & & & \\
\hline 5 & & & & \\
\hline
\end{tabular}

2. Dados de reprodução social (momento da produção - inserção no grupo/fração de classe)

Situação dos membros da família que trabalham:

\begin{tabular}{|c|c|c|c|c|c|}
\hline $\mathrm{N}^{\mathrm{o}}$ & $\begin{array}{c}\text { Atual ou última função ou } \\
\text { aquela que trabalhou por } \\
\text { mais tempo }\end{array}$ & $\begin{array}{c}\text { Curso } \\
\text { preparatório } \\
\text { para o trabalho }\end{array}$ & $\begin{array}{c}\text { Vínculo } \\
\text { atual de } \\
\text { trabalho* }\end{array}$ & $\begin{array}{c}\text { Jornada real de } \\
\text { jornada de trabalho } \\
\text { (inclua o tempo de } \\
\text { deslocamento) }\end{array}$ & $\begin{array}{c}\text { Meio de } \\
\text { transporte } \\
\text { para o } \\
\text { trabalho }\end{array}$ \\
\hline & & & & & \\
\hline & & & & & \\
\hline
\end{tabular}

*Use as seguintes alternativas para vínculo atual de trabalho: 
Bico Desempregado Trabalhador Familiar Autônomo Aposentado Assalariado sem carteira Pensionista Afastado do trabalho

Empregador Assalariado com carteira

O que o trabalho significa para o(s) entrevistado(s):

\section{Dados de reprodução social (momento do consumo - inserção no grupo/fração de classe)}

- Sua casa é:

casa/apto( ) cortiço( ) terreno comum( ) pensão( ) albergue( ) situação de rua( )

- Sua casa é:

própria( ) cedida( ) financiada( ) alugada( )

- Tipo de material da construção:

alvenaria( ) madeira( ) material reaproveitado( )

- Na sua casa de pagam essas contas:

$\begin{array}{lcl}\operatorname{luz}() & \text { água( ) } & \text { esgoto( ) condomínio( ) internet( ) TV a cabo( ) } \\ \text { IPTU( ) } & \text { coleta de lixo( ) }\end{array}$

- Alguém na sua casa sente medo de:

Desmoronamento ( ) enchente ( ) acidente de trânsito( ) contaminação com lixo,esgoto( ) contato com vetores, insetos e ratos() ameaçado por tráfico de drogas( )

- Caso haja membros em creches e escolas, especifique quais são frequentadas:

Escola/creche pública( ) escola/creche particular( ) escola particular como bolsista( ) Instituições/ONGs/programas 
- Alguém cursa faculdade: sim ( ) não( ) Se sim:

Universidade pública na cidade de São Paulo ( )

Universidade pública fora de São Paulo ( )

Universidade particular pagamento integral ( )

Universidade particular com prouni ( )

Universidade particular com Fies ( )

Universidade ligada a ONG ( )

Outras

- Quais serviços de saúde sua família utiliza:

UBS/posto de saúde( ) pronto socorro público( ) hospital público( )

Pronto socorro privado( ) hospital privado( ) CAPS( ) CECCO( ) Ambulatório de especialidades público( ) outros (como comunidades terapêuticas)

- No caso de utilizar a UBS, especifique o motivo (acompanhamento de crescimento e desenvolvimento, pré-natal, vacina, outro não relacionado à agravos/problemas de saúde instalados):

- Caso sua família precise de ajuda no bairro vocês costumam contar com:

Serviço social de alguma instituição( ) Qual:

CREAS( ) CRAS( ) amigos( ) pessoas da família que morem em outra casa( ) pessoas ligadas à igreja( ) funcionários de algum serviço (escola, posto de saúde) ( )

ONGs

Outras

Não podem contar com qualquer ajuda ( )

- Alguém recebe algum benefício do governo: sim ( ) não ( )

Se sim, qual:

Se sim, quem: 
Que atividades cada membro da família costuma fazer para distrair-se/divertir-se:

O bairro oferece espaços e atividades de lazer? Quais:

4. Dinâmica familiar (dimensão particular: relações entre os membros da família - potenciais de fortalecimento e desgaste)

Como a família se organiza no dia a dia (afazeres domésticos, compras, pagamento de contas, compromissos com a UBS, com as reuniões de escola/creche, acompanha as tarefas escolares, leva à creche/escola, e outros)

Como os membros da família se relacionam no dia a dia (espaços de convivência/trocas, tipo de comunicação, conflitos)

\section{Elabore o genograma e o ecomapa para esta família.}

6. Agravos e problemas de saúde instalados (resultados do processo saúde-doença: expressões no corpo individual):

\begin{tabular}{|c|c|c|c|}
\hline $\mathrm{N}^{\mathrm{o}}$ & $\begin{array}{c}\text { Problema de saúde/condição } \\
\text { específica* }\end{array}$ & $\begin{array}{c}\text { Acompanhamento na } \\
\mathrm{UBS}\end{array}$ & $\begin{array}{c}\text { Acompanhamento em outro } \\
\text { serviço. Qual? }\end{array}$ \\
\hline & & & \\
\hline & & & \\
\hline & & & \\
\hline
\end{tabular}


- $\quad$ Faça uma síntese de conhecimentos sobre cada um dos problemas levantados.

7. Síntese a respeito dos potenciais de fortalecimento e desgaste familiar:

8. Projeto de cuidado para apoiar a equipe de saúde: elabore, elegendo prioridades e identificando instrumentos do processo de trabalho que poderão ser utilizados como resposta às necessidades identificadas no âmbito da família:

9. Dentre as necessidades de saúde da família, indique aquelas que podem ser comuns ao grupo social ao qual a família pertence; para apoiar o cuidado oferecido pela UBS. (Ex.: creches, ambientes de socialização juvenil, saneamento básico, transporte coletivo). 